\title{
The Cretaceous and Cenozoic tectonic evolution of Southeast Asia
}

\author{
S. Zahirovic, M. Seton, and R. D. Müller \\ EarthByte Group, School of Geosciences, The University of Sydney, Sydney, NSW 2006, Australia \\ Correspondence to: S. Zahirovic (sabin.zahirovic@sydney.edu.au)
}

Received: 2 August 2013 - Published in Solid Earth Discuss.: 21 August 2013

Revised: 14 January 2014 - Accepted: 14 March 2014 - Published: 29 April 2014

\begin{abstract}
Tectonic reconstructions of Southeast Asia have given rise to numerous controversies that include the accretionary history of Sundaland and the enigmatic tectonic origin of the proto-South China Sea. We assimilate a diversity of geological and geophysical observations into a new regional plate model, coupled to a global model, to address these debates. Our approach takes into account terrane suturing and accretion histories, the location of subducted slabs imaged in mantle tomography in order to constrain the evolution of regional subduction zones, as well as plausible absolute and relative plate velocities and tectonic driving mechanisms. We propose a scenario of rifting from northern Gondwana in the latest Jurassic, driven by northward slab pull from north-dipping subduction of Tethyan crust beneath Eurasia, to detach East Java, Mangkalihat, southeast Borneo and West Sulawesi blocks that collided with a Tethyan intraoceanic subduction zone in the mid-Cretaceous and subsequently accreted to the Sunda margin (i.e., southwest Borneo core) in the Late Cretaceous. In accounting for the evolution of plate boundaries, we propose that the Philippine Sea plate originated on the periphery of Tethyan crust forming this northward conveyor. We implement a revised model for the Tethyan intra-oceanic subduction zones to reconcile convergence rates, changes in volcanism and the obduction of ophiolites. In our model the northward margin of Greater India collides with the Kohistan-Ladakh intra-oceanic arc at $\sim 53 \mathrm{Ma}$, followed by continent-continent collision closing the Shyok and Indus-Tsangpo suture zones between $\sim 42$ and $34 \mathrm{Ma}$.

We also account for the back-arc opening of the protoSouth China Sea from $\sim 65 \mathrm{Ma}$, consistent with extension along east Asia and the formation of supra-subduction zone ophiolites presently found on the island of Mindoro. The related rifting likely detached the Semitau continental fragment from South China, which accreted to northern Bor-
\end{abstract}

neo in the mid-Eocene, to account for the Sarawak Orogeny. Rifting then re-initiated along southeast China by $37 \mathrm{Ma}$ to open the South China Sea, resulting in the complete consumption of proto-South China Sea by $\sim 17 \mathrm{Ma}$ when the collision of the Dangerous Grounds and northern Palawan blocks with northern Borneo choked the subduction zone to result in the Sabah Orogeny and the obduction of ophiolites in Palawan and Mindoro. We conclude that the counterclockwise rotation of Borneo was accommodated by oroclinal bending consistent with paleomagnetic constraints, the curved lithospheric lineaments observed in gravity anomalies of the Java Sea and the curvature of the Cretaceous Natuna paleo-subduction zone. We complete our model by constructing a time-dependent network of topological plate boundaries and gridded paleo-ages of oceanic basins, allowing us to compare our plate model evolution to seismic tomography. In particular, slabs observed at depths shallower than $\sim 1000 \mathrm{~km}$ beneath northern Borneo and the South China Sea are likely to be remnants of the proto-South China Sea basin.

\section{Introduction}

Southeast Asia is an accretionary mosaic of continental fragments, seamounts, exotic terranes and intra-oceanic island arcs that were welded to the Asian continent, presently delineated by suture zones and remnants of ancient Tethyan and proto-Pacific ocean basins that once separated them (Stauffer, 1983; Şengör et al., 1988; Veevers, 2004; Metcalfe, 2011) (Fig. 1). The tectonic framework of Southeast Asia is inherited from the long-term convergence between the Australian, (proto-)Pacific and Eurasian plates and the cyclical Gondwana-derived terrane detachment and subsequent accretion onto Eurasia and the Sundaland core (Veevers et al., 


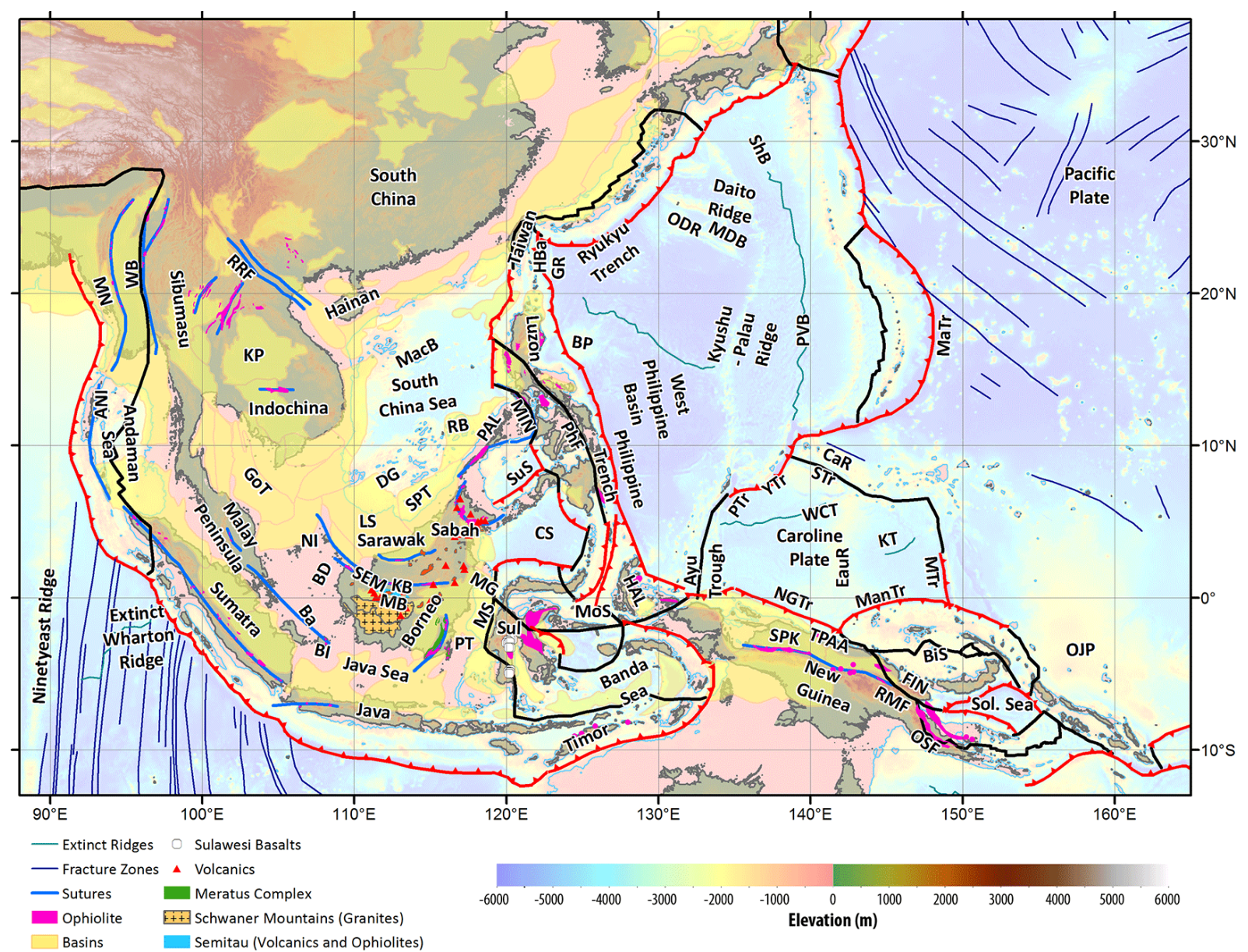

Fig. 1a. Regional tectonic setting with plate boundaries $($ MORs/transforms = black, subduction zones = teethed red) from Bird $(2003)$ and ophiolite belts representing sutures modified from Hutchison (1975) and Baldwin et al. (2012). West Sulawesi basalts are from Polvé et al. (1997), fracture zones are from Matthews et al. (2011) and basin outlines are from Hearn et al. (2003). ANI-Andaman and Nicobar Islands, BD-Billiton Depression, Ba-Bangka Island, BI-Belitung (Billiton) Island, BiS - Bismarck Sea, BP-Benham Plateau, CaRCaroline Ridge, CS - Celebes Sea, DG - Dangerous Grounds, EauR - Eauripik Ridge, FIN - Finisterre Terrane, GoT - Gulf of Thailand, GR Gagua Ridge, HAL - Halmahera, HBa - Huatung Basin, KB - Ketungau Basin, KP - Khorat Platform, KT - Kiilsgaard Trough, LS - Luconia Shoals, MacB - Macclesfield Bank, ManTr-Manus Trench, MaTr-Mariana Trench, MB - Melawi Basin, MDB - Minami Daito Basin, MG - Mangkalihat, MIN - Mindoro, MN - Mawgyi Nappe, MoS - Molucca Sea, MS - Makassar Straits, MTr-Mussau Trench, NGTr - New Guinea Trench, NI - Natuna Islands, ODR - Oki Daito Ridge, OJP - Ontong Java Plateau, OSF - Owen Stanley Fault, PAL - Palawan, PhF Philippine Fault, PT - Paternoster Platform, PTr-Palau Trench, PVB - Parece Vela Basin, RB - Reed Bank, RMF-Ramu-Markham Fault, RRF-Red River fault, SEM - Semitau, ShB - Shikoku Basin, Sol. Sea-Solomon Sea, SPK-Sepik, SPT-Sabah-Palawan Trough, STrSorol Trough, Sul-Sulawesi, SuS-Sulu Sea, TPAA-Torricelli-Prince Alexander Arc, WB-West Burma, WCT-W Caroline Trough, YTr - Yap Trough.

1991; Acharyya, 1998; Golonka, 2004; Hall, 2002; Stampfli and Borel, 2002; Metcalfe, 2006). The northern Gondwana margin, as the origin for many of the Asian continental fragments, was a passive boundary for much of the Mesozoic, with periodic rifting events that carried continental slivers on the Tethyan oceanic plates that acted as conveyors transferring terranes onto the southern Eurasian margin (AudleyCharles, 1988; Veevers et al., 1991; Seton et al., 2012).

The Sundaland core, forming much of the Sunda shelf and continental promontory in Southeast Asia (Fig. 2), is largely composed of the Cimmerian terranes that rifted from Gond- wana at early Permian times (Metcalfe, 2011) to open the Meso-Tethys at the expense of the Paleo-Tethys (Table 1) and accreted diachronously along the Eurasian margin during the Triassic and Jurassic (Golonka, 2007; Metcalfe, 1999; Seton et al., 2012; Stampfli and Borel, 2002). A latest Jurassic rifting episode along northern Gondwana likely detached continental fragments including West Sulawesi, Mangkalihat, East Java, parts of Borneo (Hall, 2011; Metcalfe, 2011; Wakita, 2000) and other potential microcontinents such as Sikuleh, Natal, Lolotoi and Bengkulu (Acharyya, 1998; Metcalfe, 1996), to open the Neo-Tethys. However, the origin 

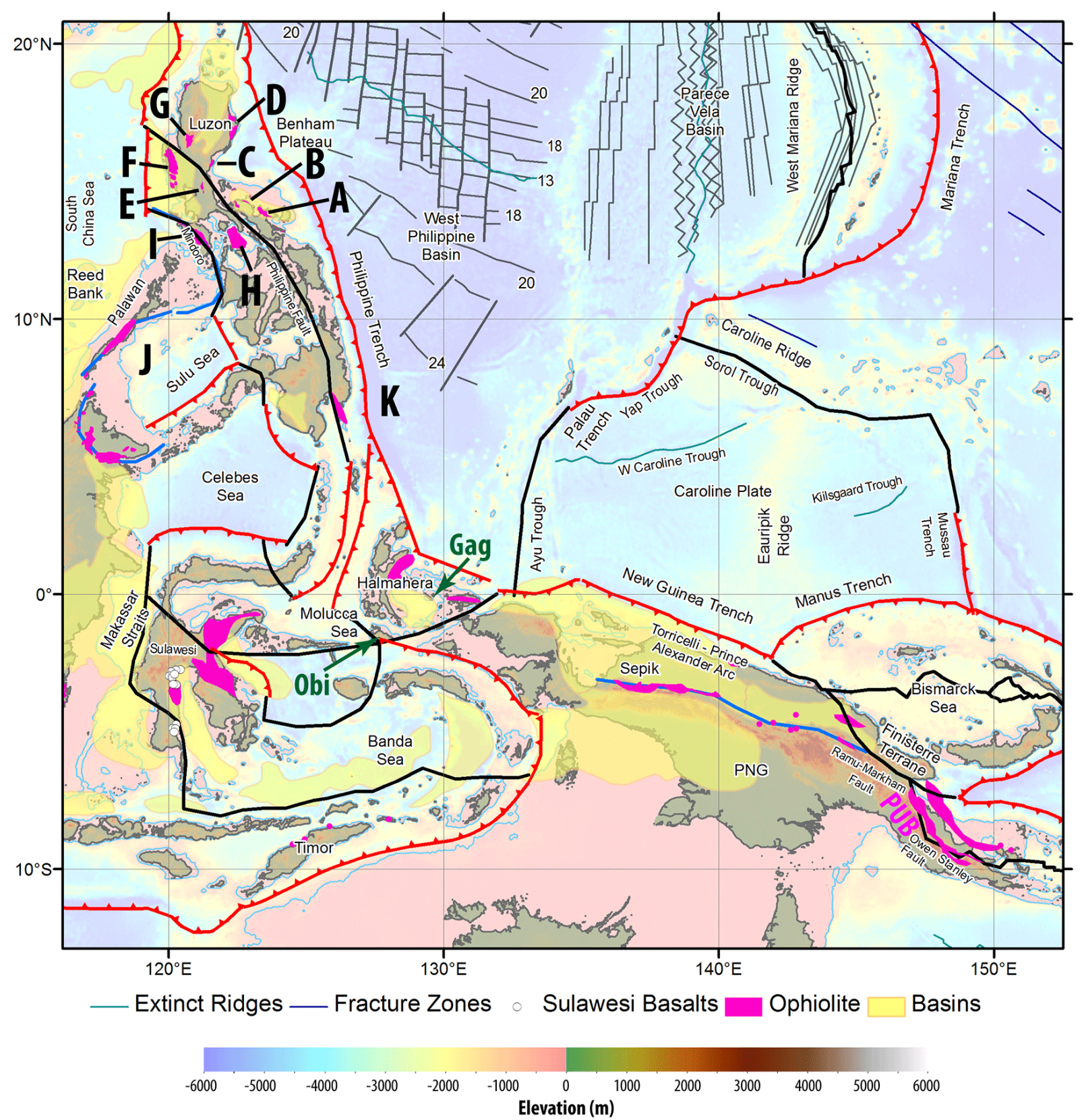

Fig. 1b. Regional tectonic setting of the Philippine Sea plate, Papua New Guinea and the Caroline Plate, following symbology of Fig. 1. The crystallization ages of ophiolites were used to infer oceanic crust age, while the metamorphic age was used to infer collision and obduction. A - Lagonoy Ophiolite, B - Calaguas Ophiolite, C-Dibut Bay Ophiolite, D-Casiguran Ophiolite, E-Montalban Ophiolite, F-ZambalesAngat Ophiolite, G-Itogon Ophiolite, H-Marinduque Basin/Sibuyan Ophiolite, I-Mindoro/Amnay ophiolites, J-Palawan Ophiolite, KPujada Ophiolite, PUB - Papuan Ultramafic Belt, COPB - central ophiolite belt.

of these blocks on the northern Gondwana margin is controversial, in particular whether they all originated from the Argo Abyssal Plain, hence the "Argoland" name applied to blocks from this segment of the northwest Australian shelf, or whether some of these blocks originated from the New Guinea or even Greater Indian passive margin. In addition, the nature of the microcontinents on Sumatra has been dis- puted, and recent studies have argued that these are more likely to be accreted intra-oceanic island arcs with no continental basement (Barber, 2000; Barber and Crow, 2003; Barber and Crow, 2009).

Although oceanic crust adjacent to the northwest Australian shelf records Neo-Tethyan seafloor spreading, only dismembered fragments of obducted oceanic crust in suture 
Table 1. Summary of the terrane accretions and nomenclature for the Tethyan oceanic domains used in this study following Seton et al. (2012).

\begin{tabular}{llll}
\hline Region & $\begin{array}{l}\text { Central Tethys } \\
\text { (present-day } \\
\text { India-Lhasa) }\end{array}$ & $\begin{array}{l}\text { Eastern Tethys } \\
\text { (present-day West } \\
\text { Burma and Sumatra) }\end{array}$ & $\begin{array}{l}\text { Eastern Tethys } \\
\text { (present-day } \\
\text { Sundaland) }\end{array}$ \\
\hline Eurasia & Qiangtang & Indochina & Indochina \\
\hline $\begin{array}{l}\text { Cimmerian blocks } \\
\text { (Sundaland core) } \\
\text { rifted from northern } \\
\text { Gondwana }\end{array}$ & Lhasa & Paleo-Tethys & \\
\hline & & $\begin{array}{l}\text { Sibumasu, } \\
\text { West Sumatra }\end{array}$ & $\begin{array}{l}\text { Malay Peninsula, } \\
\text { southwest Borneo } \\
\text { core }\end{array}$ \\
\hline $\begin{array}{l}\text { Latest Jurassic } \\
\text { rifted blocks } \\
\text { from northern }\end{array}$ & & Meso-Tethys & \\
Gondwana & & $\begin{array}{c}\text { Argoland? } \\
\text { Mawgyi? }\end{array}$ & $\begin{array}{l}\text { West Sulawesi, } \\
\text { Mangkalihat, } \\
\text { East Java, }\end{array}$ \\
\hline & & Sikuleh? & easternmost Borneo \\
\hline $\begin{array}{l}\text { Gondwana breakup } \\
\text { in Early Cretaceous }\end{array}$ & India & Australia & proto-Molucca Sea \\
\hline
\end{tabular}

Indian-Southern Ocean

zones give a glimpse of the older Meso- and Paleo-Tethyan oceanic domains (Seton et al., 2012). For example, the only preserved oceanic crust of the latest Jurassic seafloor spreading episode is contained in the obducted basement of the central ophiolite belt on New Guinea (Fig. 1b), likely preserved in an embayment along New Guinea (Hill and Hall, 2003). The lack of preserved seafloor spreading histories results in uncertain placements and tectonic reconstructions of many terranes presently found in Southeast Asia. As a result, we flag instances where alternative tectonic scenarios can explain the piecemeal data coverage in the absence of conclusive full fit reconstructions between two conjugate continental margins. This region, as the link between the Tethys and (proto-)Pacific, is complex also because of the uncertain nature of plate boundaries that accommodated generally westward subduction of (proto-)Pacific oceanic crust beneath east Asia and the overall northward subduction of Tethyan seafloor beneath southern Eurasia. Many of these accretionary events and convergence histories between the Indo-Australian, Pacific and Eurasian plates are recorded in the tectonic fabric of Sundaland. However, a large portion of the Sundaland continental promontory is below sea level and sampling localities are difficult to access (Fig. 2), resulting in uncertain tectonic histories of accreted blocks - including their origin, tectonic stability and accretionary chronology. In particular, the evolution of the southwest Borneo core and rotation since the Late Cretaceous is intricately linked to the complex interactions related to opening and closure of the proto-South China Sea and the evolution of its successor, the South China Sea (Hutchison, 1996), as well as the collision of microcontinental fragments and island arcs from the south and east.

\section{Previous work}

There have been numerous plate reconstructions of the region, from the very early works of Ben-Avraham and Uyeda (1973) reconstructing the South China Sea and east Asian margin, to the paleomagnetic data and interpretations provided by Haile et al. (1977), who were the first to propose that the southwest Borneo core and the Malay Peninsula were one cohesive tectonic unit since at least the mid-Cretaceous. The study of Hutchison (1975) mapped out the suture zones and ophiolite belts in Southeast Asia, which provided important chronological and tectonic constraints on major collisional events resulting in suturing of continental blocks and island arcs in the region. Early studies also incorporated arc volcanism related to the tectonic evolution of Indonesia and Sundaland (Katili, 1971, 1975; Bignell, 1972), which suggested that the two opposing magmatic arcs preserved on Sundaland are at least Cretaceous in age - one from northdipping Tethyan subduction, and another west and southdipping subduction along east Asia and northern Borneo. Importantly, a Permian volcanic arc that links the Malay Peninsula and the southwest Borneo core was also proposed. The continuity of the east Asian volcanic arc, and critical geochronological constraints on these "thermal episodes" emplacing subduction-related volcanism in two major postJurassic phases from $\sim 170$ to $130 \mathrm{Ma}$ and between 120 to $60 \mathrm{Ma}$ were synthesized by Jahn et al. (1976). 


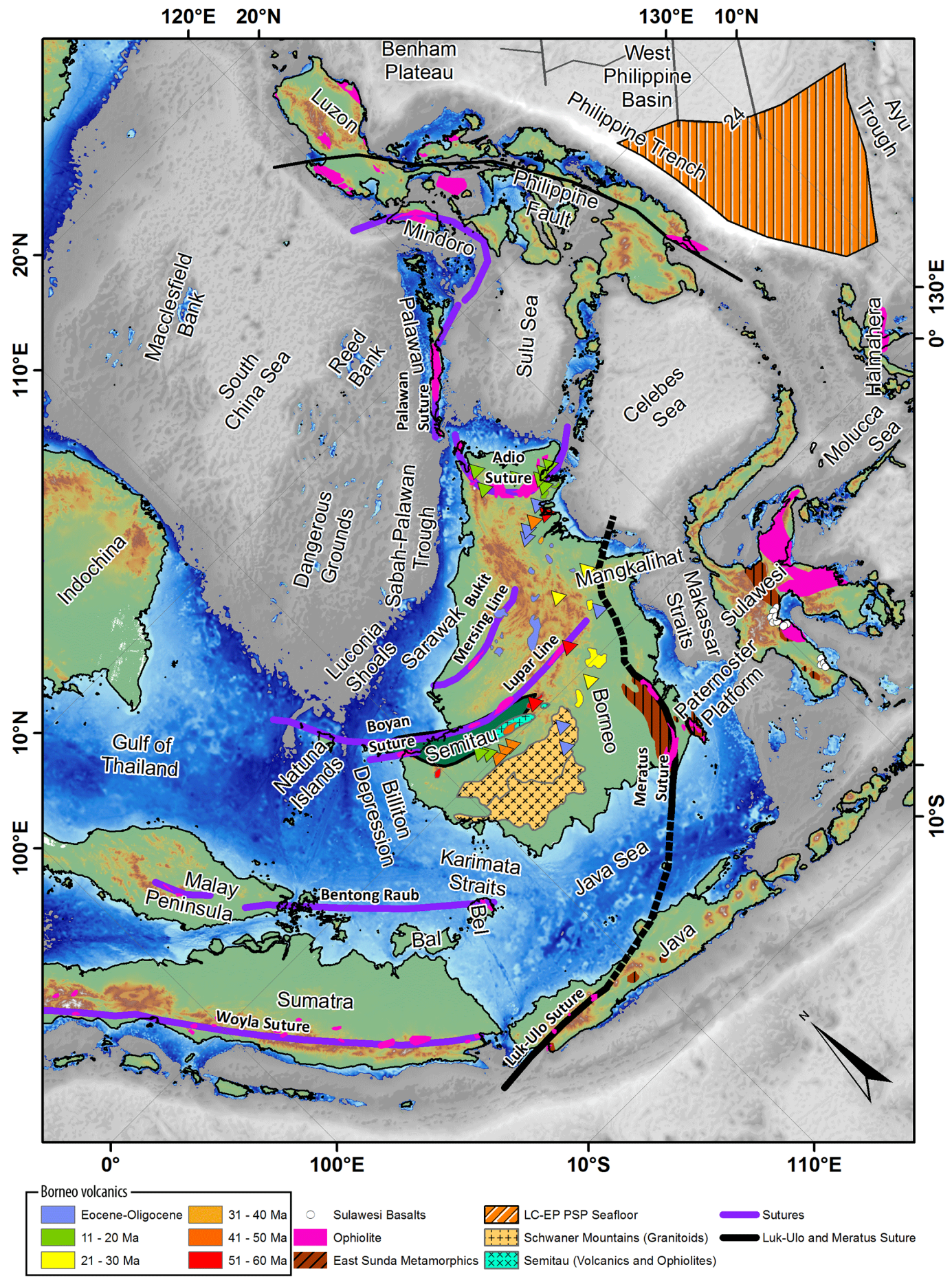

Elevation $(\mathbf{m})$

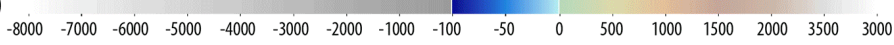

Fig. 2. Sundaland suture distributions with the Cretaceous-age Luk-Ulo and Meratus sutures resulting from the accretion of East Java, easternmost Borneo, Mangkalihat and West Sulawesi. The Billiton Depression has been previously invoked as a Cretaceous suture resulting from the docking of southwest Borneo with Sundaland. However, little evidence has been presented to indicate that this is a (Cretaceousage) suture. We interpret the Schwaner granitoids to be continuous with the Natuna Arc and the Fukien-Reinan Massif (see Fig. 6) as an Andean-style subduction zone along east Asia in the Cretaceous. The Boyan Suture and Lupar Line bound the Semitau block (dark green) that accreted to northern Borneo in the mid-Eocene to result in the Sarawak Orogeny. LC-EP PSP-Late Cretaceous(?)-early Paleogene Philippine Sea plate seafloor crust. Eocene to Holocene volcanics on Borneo are age-coded from Soeria-Atmadja et al. (1999). 
The 1970s also heralded the first regional plate reconstructions that incorporated the western Pacific plate boundaries (Hilde et al., 1977; Weissel et al., 1978) and the origin and evolution of the para-autochthonous Sula Spur (AudleyCharles et al., 1979; Norvick, 1979) interacting with the allochthonous Banda Arc. This time also marked the development of analogue plasticine experiments that demonstrated northward indentation, namely from the collision of the Indian continent with Eurasia, was likely responsible for the extrusion tectonics resulting in large offset strike-slip boundaries throughout much of Southeast Asia (Molnar and Tapponnier, 1975; Tapponnier et al., 1982). The missing piece of the puzzle in Southeast Asian plate reconstructions, namely the Philippine Sea plate as the link between the Asian, IndoAustralian and Pacific convergent zones, attracted attention in the 1980s, with studies focusing on paleomagnetic measurements (Fuller et al., 1983) and dating of ophiolite belts on Luzon and other parts of the Philippine Archipelago (Hawkins and Evans, 1983; Karig, 1983; Rangin et al., 1985; Sarewitz et al., 1986; Geary et al., 1988). New models for the seafloor spreading history of the West Philippine Basin (Hilde and Chao-Shing, 1984) were incorporated in regional reconstructions of the West Pacific basins and Southeast Asia (Holloway, 1982; Jolivet et al., 1989; Rangin et al., 1990) for the Eocene. Regional syntheses that went further back in time and included the history of Gondwana-derived continental fragments (Veevers, 1991; Veevers et al., 1991) were complemented with detailed reconstructions of Southeast Asia (Hall, 1996, 2002; Metcalfe, 1996; Pubellier et al., 2003). The reconstructions of Lee and Lawver $(1994,1995)$ were an important contribution as they highlighted the need to publish and share the Euler rotations implied by their plate motion models, so that the models become testable and expandable. We follow this community-based framework and propose a regional model of Southeast Asia embedded into a global plate motion model that is testable and easily modifiable in digital form.

We present a plate motion model with continuous plate boundary evolution, seafloor age grids and plate velocity reconstructions of Sundaland in the context of terrane accretions, island arc collisions and the opening and closure of marginal seas. We assimilate a diverse range of geological and geophysical data (see Sect.. 2, Table 2 and Fig. 3), and draw on previously published kinematic models, to reconcile the chronology and tectonic evolution of the latest Jurassic rifting event from northern Gondwana and the subsequent accretion and growth of Sundaland since the Cretaceous. In addition, we use seismic tomographic constraints to estimate paleo-locations of subduction zones in the region. The model we present invokes long-lived north-dipping subduction along Eurasia during the Jurassic and Cretaceous, with microcontinental slivers detaching from northern Gondwana and accreting to Sundaland. We provide the digital files (rotations, tectonic elements including digitized ophiolite belts, volcanics and other tectonic features) and tools (plate recon- struction software GPlates, www.gplates.org) in order that our model may be tested and improved.

\section{Methodology}

We assimilate geological data (Table 2) and previously published models (Supplement Table A1) of extensional tectonic settings, shallow marine paleobiogeography, basaltic volcanism and ophiolite formation, determined by mineral crystallization ages, to constrain rifting events along northern Gondwana in the latest Jurassic. Proxies for convergence including subduction-related volcanics and metamorphic belts (Fig. 3 and Supplement Fig. A1) are used to infer subduction polarities, and collisional events are inferred from the spatiotemporal distribution of ophiolite obduction episodes, ultra-highpressure (and high-temperature) metamorphism and collisional orogenesis. Our base global plate motion model includes relative plate motions for Southeast Asia based on the syntheses of Lee and Lawver (1994, 1995), Hall (1996, 2002, 2012), Metcalfe (1994, 1996, 1999, 2011), Pubellier et al. (2003), Golonka (2004, 2007), Golonka et al. (2006) and other data and models described in Seton et al. (2012). We incorporate a range of data sets and models specific to Southeast Asia, and in particular the development and evolution of Sundaland, the South China Sea, the Philippine arcs and the accretionary history of northern New Guinea (Table 2, Fig. 3).

We implement a new model for the intra-oceanic subduction in the Neo-Tethys, based on the models of Ali and Aitchison (2008), Zahirovic et al. (2012), Burg (2011) and recent data and interpretations from Bouilhol et al. (2013) to link the intra-oceanic subduction in the central Neo-Tethys involving the Kohistan-Ladakh arc system (i.e., accommodating India-Eurasia convergence) eastward to the Woyla back arc along West Burma and Sumatra (Fig. 1). The Late Jurassic ages of shallow marine sandstones from the Bantimala Complex on West Sulawesi (Supplement Fig. A1), along with the Late Jurassic-Early Cretaceous (158-137 Ma) mafics on West Sulawesi (Polvé et al., 1997), are assumed to indicate rifting from the Gondwana margin and the formation of ophiolites (i.e., crystallization ages). Accretion events are interpreted from the onset of ultra-highpressure and temperature metamorphism indicative of collision, changes in the style of volcanism and the obduction of ophiolites (i.e., metamorphic ages). For Sundaland, the Meratus Suture in southeast Borneo and the Luk-Ulo Suture on Java (Fig. 2) record a mid- to Late Cretaceous accretion event, accompanied by ophiolite obduction and ultrahigh-pressure and high-temperature metamorphism (Wakita, 2000) that include greenschists, blueschists and eclogites (Parkinson et al., 1998). The present-day geometry of this suture zone is delineated regionally using the distribution of ophiolites, previously identified suture zone outcrops, gravity anomalies and high vertical gravity gradients that represent 


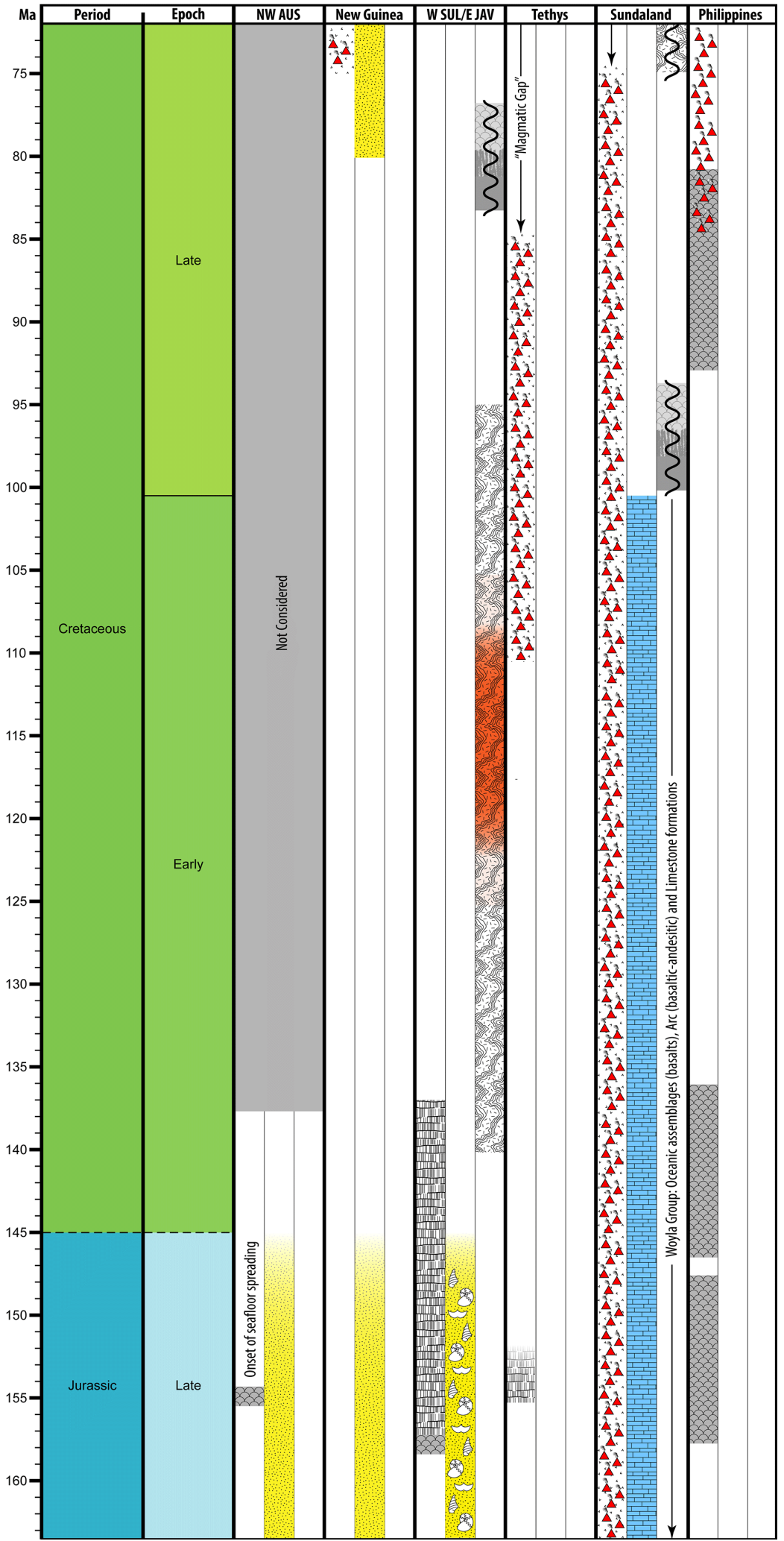

Fig. 3. Summary of first-order tectonic events related to the latest Jurassic Gondwana rifting and the evolution of the Tethys and Sunda region since the Cretaceous. For each region major volcanic (left column), sedimentary (middle column) and metamorphic (right column) events are documented. HEB - Hawaiian-Emperor Bend time based on Sharp and Clague (2006), K/L - Kohistan-Ladakh, PA-F-T = Prince Alexander-Finisterre-Torricelli. 


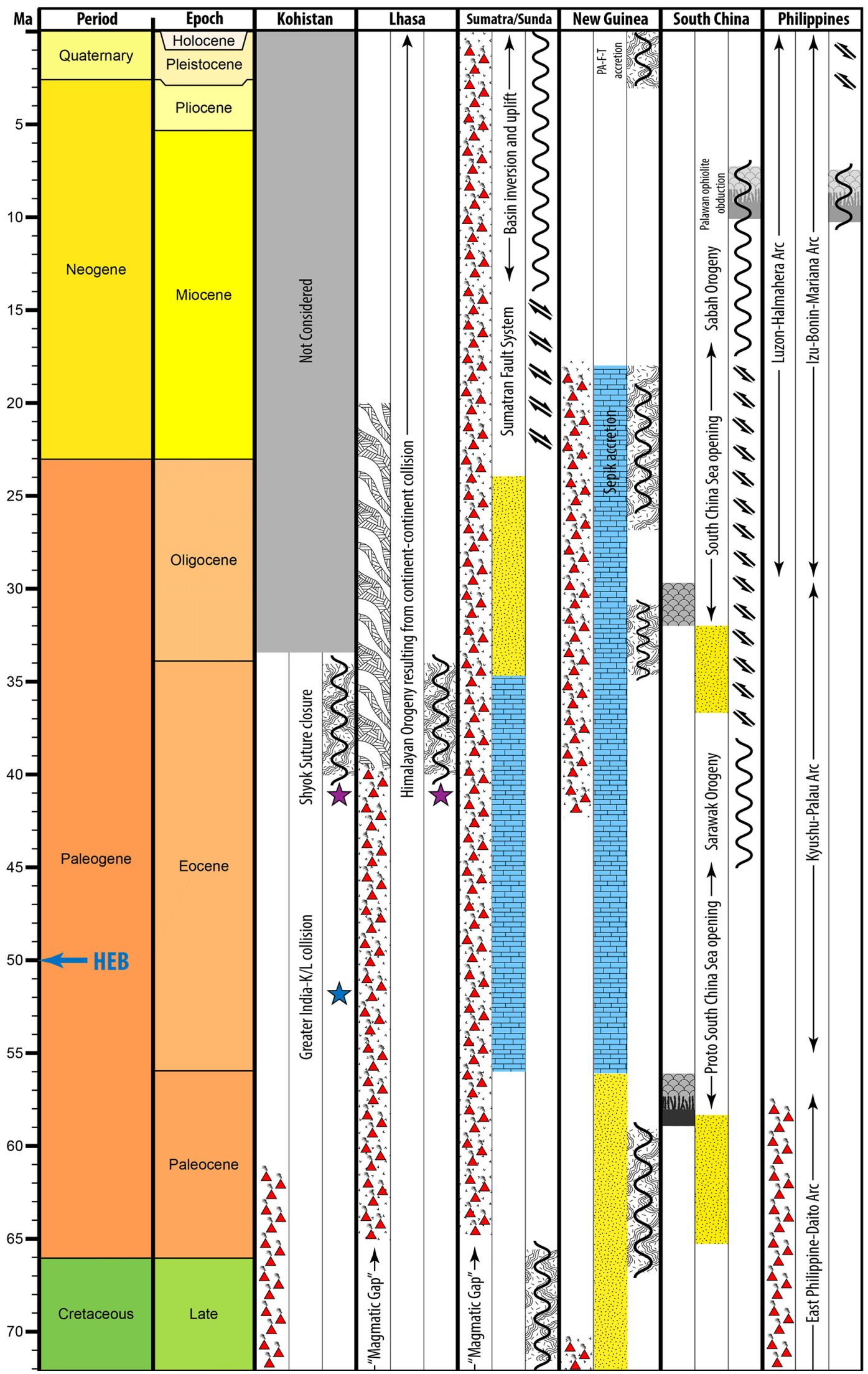

Fig. 3. Continued. 

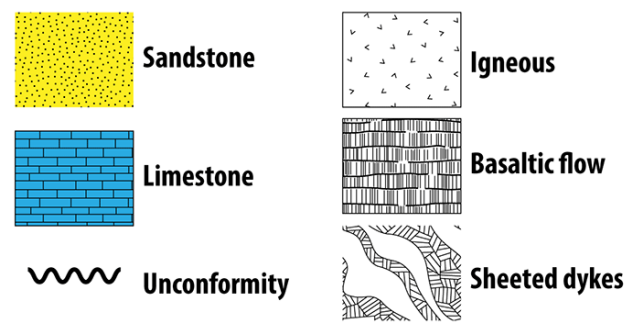

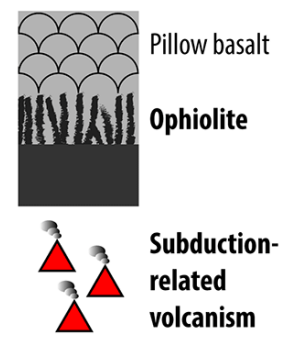

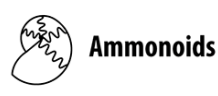
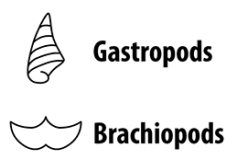

Fig. 3. Continued.

lithospheric-scale structures, mapped from the $1 \mathrm{~min}$ World Gravity Map (Balmino et al., 2012) (Figs. 4 and 5).

\subsection{Reconstructions of Borneo and Sundaland}

To determine the biogeographic affinity of Borneo with either Gondwana or Asia, we use the global open-access community Paleobiology Database (now Fossilworks), and extract all fossil occurrences in the Triassic and Jurassic. The sampled fossil collections are situated approximately within the Semitau block as described by Metcalfe (1996) (Fig. 6). Further paleobiogeographic work, including the use of molecular clocks, may help fine-tune tectonic affinities as demonstrated by Holloway and Hall (1998) - including the location of the southwest Borneo core in pre-Cretaceous times. The rotation of Borneo, relative to Sundaland, has been estimated using careful analysis of paleomagnetic data collected from the region (Haile et al., 1977; Fuller et al., 1995). Although a rotation magnitude can be estimated from paleomagnetic data, it is more difficult to determine the pole of rotation relative to Sundaland. We hypothesize that the curved structural lineaments in the Java Sea, used by Hutchison (2010) to infer oroclinal bending, may be used as a guide to derive the motion of Borneo relative to Sundaland (primarily Sumatra and northern Java), and therefore Eurasia, in the Cenozoic (see Sect. 2.5 and Fig. 7).

\subsection{Regional plate reconstructions in a global and open-source framework}

Our plate motion model, using the Seton et al. (2012) global model as a starting point, is constructed using open-source and cross-platform plate reconstruction software, GPlates (www.gplates.org). We interactively derived and modified the finite Euler rotations of blocks using GPlates (Boyden et al., 2011) and placed them in their approximate pre-rift positions on the northern Gondwana continental margin. A full fit reconstruction was not possible in order to precisely place East Java, East Borneo and West Sulawesi due to the lack of preserved conjugate passive margins. As a result, our interpreted pre-breakup positions of these blocks are approximate, following the constraints discussed in text and summarized in Table 2, and will need further refinement as more data become available. Present-day terrane outlines, includ-

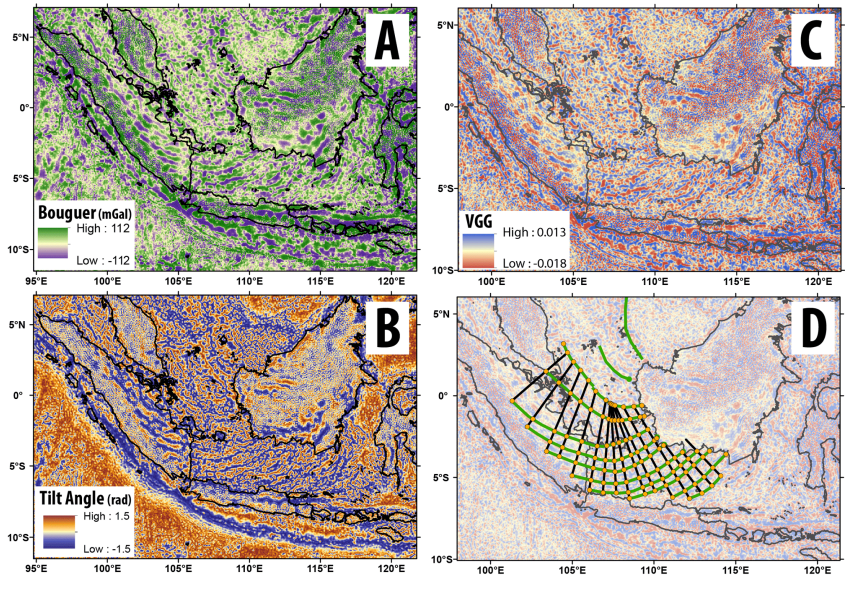

Fig. 4. Band-pass-filtered (150 to $10 \mathrm{~km}$ ) Bouguer gravity anomalies (A) from the $1 \mathrm{~min}$ World Gravity Map (Balmino et al., 2012) highlight the large-scale structures and the curved lineaments on Sundaland, resulting from oroclinal bending as proposed by Hutchison (2010). Bouguer gravity tilt angle derivatives (B) and vertical gravity gradients $(\mathbf{C})$ were derived from the Bouguer anomalies and were also band-pass-filtered $(150$ to $10 \mathrm{~km})$ to remove noise from small-scale structures. The vertical gravity gradient was used as a guide to digitize the curved lineaments on Sundaland (green, D). The Cretaceous Woyla, Luk-Ulo and Meratus sutures, along with the Paleozoic Bentong-Raub suture, retain a strong signature of a lithospheric-scale discontinuity. Conversely, the Billiton Depression is not observable as a generally north-south cross-cutting lithospheric-scale heterogeneity, and instead is likely to be a bathymetric anomaly related to rifting in the West and East Natuna basins.

ing continental blocks, island arcs, and igneous products in the oceans are adopted from Seton et al. (2012) in the reconstructions. For blocks in Southeast Asia, more detail was introduced (Figs. 1 and Fig. 12a) by delineating terrane boundaries using major regional (lithospheric-scale) faults from Hearn et al. (2003) and Metcalfe (2011), guided also by gravity anomalies (Sandwell and Smith, 2009; Balmino et al., 2012), ophiolites and sutures (Hutchison, 1975; Wakita, 2000). Plate boundaries were digitized, and evolving plate polygon topologies were constructed from their intersections following Gurnis et al. (2012). This approach allows plate boundaries to move relative to one another - for example, 
Table 2. Data and interpretations used for constructing plate motion model.

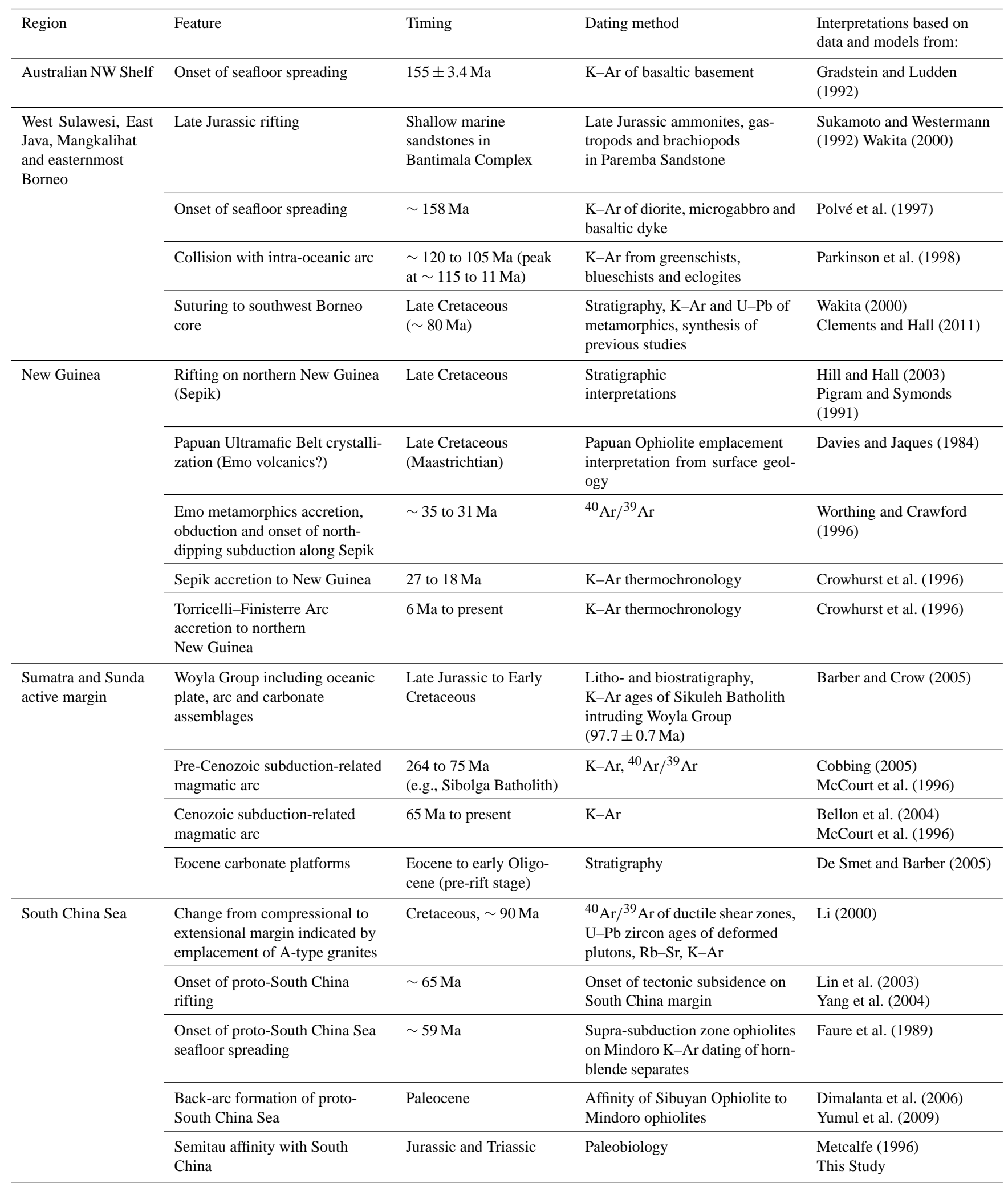


Table 2. Continued.

\begin{tabular}{|c|c|c|c|c|}
\hline Region & Feature & Timing & Dating method & $\begin{array}{l}\text { Interpretations based on } \\
\text { data and models from: }\end{array}$ \\
\hline \multirow[t]{6}{*}{ South China Sea } & \multirow[t]{2}{*}{$\begin{array}{l}\text { Semitau (and Luconia-Balingian } \\
\text { continent?) collision with } \\
\text { northern Borneo }\end{array}$} & Eocene & Inversion of regional basins & Fyhn et al. (2010a) \\
\hline & & Eocene $(\sim 37 \mathrm{Ma})$ & $\begin{array}{l}\text { Sarawak Orogeny related to Sibu } \\
\text { Zone uplift }\end{array}$ & Hutchison (2004) \\
\hline & $\begin{array}{l}\text { Onset of rifting in the South } \\
\text { China Sea }\end{array}$ & Eocene $(\sim 37 \mathrm{Ma})$ & $\begin{array}{l}\text { Interpretations of seismic } \\
\text { sections, stratigraphy and } \\
\text { tectonic subsidence }\end{array}$ & $\begin{array}{l}\text { Hutchison (2004) } \\
\text { Briais et al. (1993) } \\
\text { Lin et al. (2003) } \\
\text { Yang et al. (2004) }\end{array}$ \\
\hline & Onset of seafloor spreading & $\sim 32 \mathrm{Ma}$ & $\begin{array}{l}\text { Magnetic anomaly identifications } \\
\text { in the South China Sea }\end{array}$ & Briais et al. (1993) \\
\hline & $\begin{array}{l}\text { Collision and attempted sub- } \\
\text { duction of Dangerous } \\
\text { Grounds-Reed Bank along } \\
\text { northern Borneo (originating on } \\
\text { South China margin) }\end{array}$ & $\sim 17 \mathrm{Ma}$ & Sabah Orogeny & $\begin{array}{l}\text { Hutchison (1996) } \\
\text { Hutchison et al. (2000) }\end{array}$ \\
\hline & $\begin{array}{l}\text { Collision of northern Palawan } \\
\text { and obduction of ophiolites }\end{array}$ & Early Miocene & $\begin{array}{l}\text { Interpretations from stratigraphy } \\
\text { and surface geology }\end{array}$ & Yumul Jr. et al. (2003) \\
\hline
\end{tabular}

subduction zones are tied to their overriding plate, whilst mid-oceanic ridges move at half stage rotations between the two flanking plates. Following initial user input, GPlates calculates the plate boundary intersections on the fly to result in resolved plate topologies that can be used to extract velocities and plate boundary configurations. Velocities were sampled from a $100 \mathrm{~km}$-resolution mesh with equally spaced nodes to generate absolute plate velocity grids (Fig. 12b). The absolute reference frame underlying our global plate motions is a combination of a true-polar wander-corrected reference frame between 200 and $100 \mathrm{Ma}$ (Steinberger and Torsvik, 2008) and a global moving hotspot reference frame since $100 \mathrm{Ma}$ (Torsvik et al., 2008a). Tethyan spreading history has been revised following a re-interpretation of magnetic anomalies off the northwest Australian shelf (Gibbons et al., 2012) and the incorporation of rotations that account for fullfit reconstructions and continental deformation during rifting of Australia from Antarctica from $\sim 160$ to $83 \mathrm{Ma}$ (Williams et al., 2011). Resolved topological plate boundaries, block outlines and model rotation files, along with animations of a hemispherical and regional view and digitized regional geological features are included in the Supplement.

\subsection{Plate kinematic considerations}

We supplement geological evidence and previously published models with additional criteria of convergence rate thresholds across evolving plate boundaries and apply geometric rules of triple junction closure. Firstly, no part of a purely synthetic plate (i.e., proto-South China Sea) is allowed to have velocities exceeding $25 \mathrm{~cm} \mathrm{yr}^{-1}$, following the velocity threshold used by Stampfli and Borel (2002).
Secondly, mid-ocean ridge triple junctions in a ridge-ridgeridge configuration (as in our eastern Tethys model from $\sim 155 \mathrm{Ma})$ must accommodate seafloor spreading on all three arms following McKenzie and Morgan (1969). Thirdly, changes in relative plate motions can alter the type of plate boundary - for example, the predecessor to the (proto-)IzuBonin-Mariana Arc is a transform that eventually becomes a west-dipping subduction zone consuming Pacific crust, following the model of Casey and Dewey (1984) and Stern and Bloomer (1992). In the eastern Tethys we invoke the conversion of transform boundary to a spreading center following a change in relative plate motions from strike-slip to extensional, using the analogue of the San Andreas strike-slip boundary in the Gulf of California. Extension in the Gulf of California initiated sometime after $\sim 12.5 \mathrm{Ma}$, following subduction cessation and the transfer of the Baja Peninsula from North America to the Pacific Plate, which resulted in seafloor spreading (Oskin and Stock, 2003; Mammerickx and Klitgord, 1982; Spencer and Normark, 1979; Karig and Jensky, 1972). Lastly, plate boundary configurations must be consistent with relative plate motions - for example, convergence between two plates must be accommodated by subduction or continental crustal shortening (orogenesis), extension along rifts or mid-oceanic ridges, and conservation of crust along transforms. Although the rigid block rotations in our model imply shortening or extension of continental crust, future work will involve creating a deforming plate model for the region. 

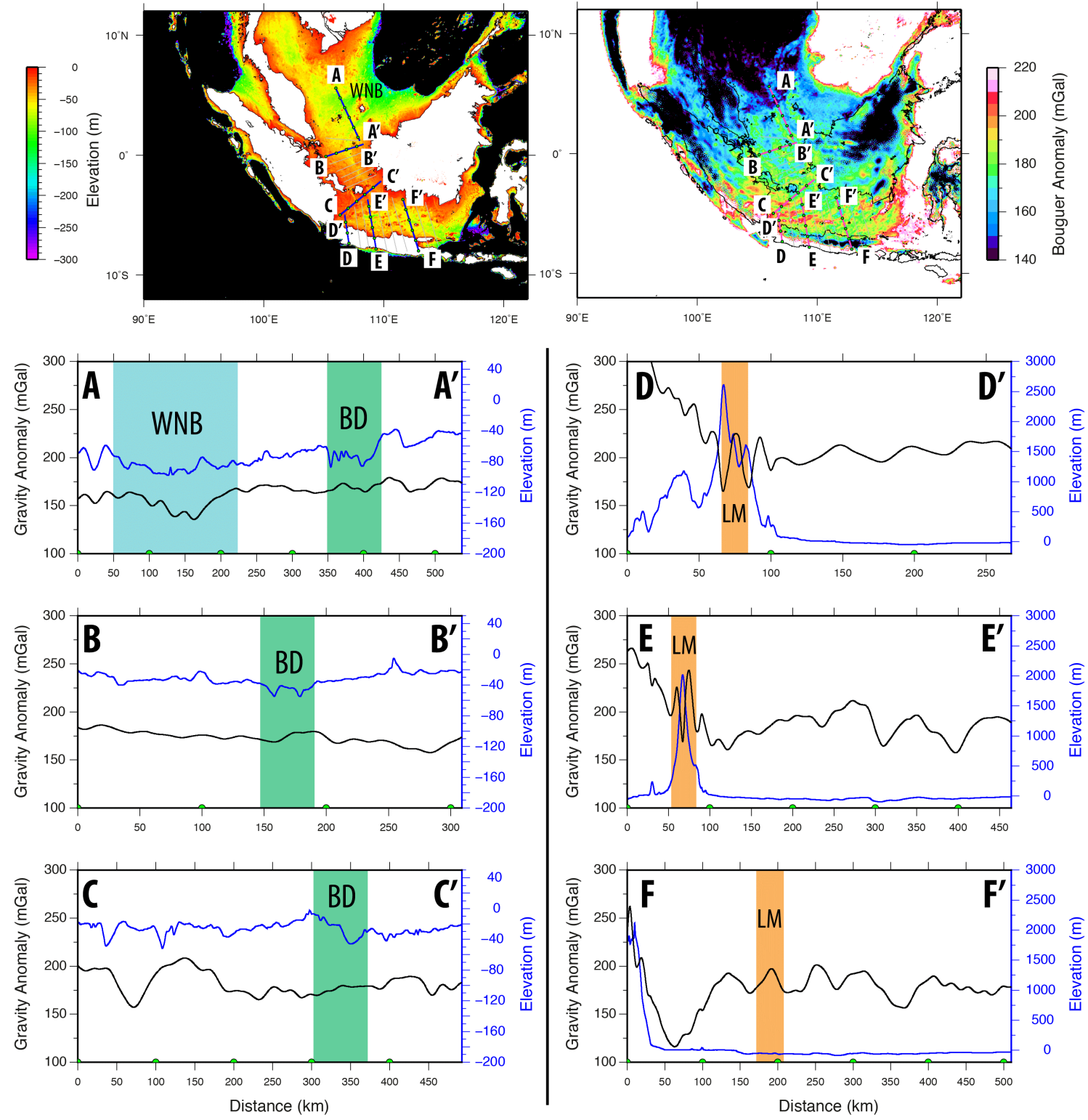

Fig. 5. Global Multi-Resolution Topography from Ryan et al. (2009) (top left) and gravity anomalies from Balmino et al. (2012) (top right) with profiles through the West Natuna Basin and Billiton Depression (A, B and $\mathbf{C})$, compared to the signature of the Luk-Ulo and Meratus sutures in the Java Sea (D, E and F). The Billiton Depression ("BD") is not a large bathymetric anomaly of $\sim 20$ to $40 \mathrm{~m}$ relative to the surrounding Sunda Shelf. The Billiton Depression, often referred to as a Cretaceous-age suture zone (Hall, 2012; Metcalfe, 2012), does not intercept any emergent land, and therefore no suture rocks or related features (ophiolites, large-scale faults, etc.) have been reported, and does not exhibit a gravity signature that can be easily traced through Sundaland. Conversely, the Luk-Ulo and Meratus sutures ("LM") on Java and eastern Borneo have well-documented exposures of suture zone material, exhibit up to a $\sim 2500 \mathrm{~m}$ topographic anomaly (D) and can be followed in the gravity signature of the Java Sea (Bouguer anomaly of $\sim 50 \mathrm{mGal}$ ). We therefore interpret that the Billiton Depression is related to the Oligocene onset of rifting in the West and East Natuna basins, and is not a pre-existing Cretaceous-age suture as proposed by Hall (2012). The location of the profiles is plotted on the bathymetry and gravity anomaly grids (top), and the grey lines represent additional profiles that are included as an animation in the Supplement.

\subsection{Seismic tomographic constraints in the Cenozoic for the circum-Philippine trenches}

Subduction polarities are inferred from subduction-related volcanism on the overriding plate. Additionally, seismic to- mographic models of the mantle are used to infer subduction histories for the Philippine Sea plate and the New Guinea margin for the Cenozoic, due to the ambiguities in the geological data and the dominant influence of subduction on these margins during this time. Depth slices of slab mate- 


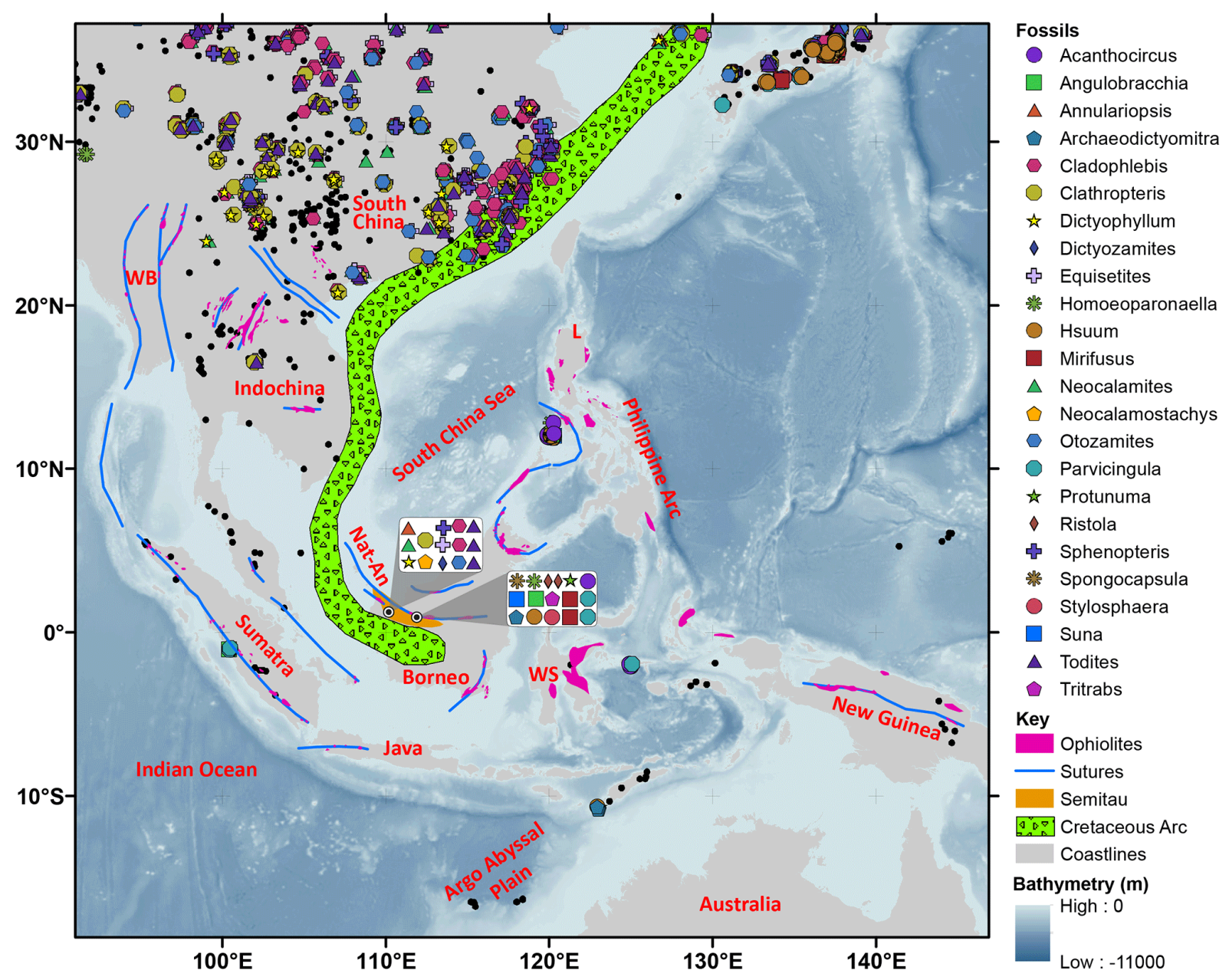

Fig. 6. Triassic and Jurassic fossil occurrences from the global Paleobiology Database (now Fossilworks), representing 24 fossil genera ( 30 samples from two locations), are found on Borneo within the Semitau continental block (orange). The paleobiological affinity between South China and this part of Borneo is significant during this time, suggesting that the Semitau continental fragment likely originated on the South China margin. The Natuna-Anambas Arc across central present-day Borneo represents the westward-dipping subduction zone that consumed the proto-Pacific, likely linked the east Asian volcanic arc (including the Fukien-Reinan Massif, modified from Honza and Fujioka, 2004) with the Schwaner Mountain granitoids in southwest Borneo. The age of the volcanics are at least Middle Jurassic, and likely indicate that the southwest Borneo core was part of Sundaland since at least the Middle Jurassic, and was unlikely a latest Jurassic Gondwanan allochthon. Although sampling of Indochina may be lower than of South China, the fossil occurrences do not indicate tectonic affinity between Indochina and Semitau (Borneo) during the Triassic and Jurassic. Paleobiological data from the global Paleobiology Database suggest that the Semitau block was along the South China mainland during the Triassic and Jurassic, and we interpret that it was rifted from this margin in the latest Cretaceous-early Eocene to open the proto-South China Sea in a back-arc setting. Nat-An-Natuna-Anambas Arc, WB - West Burma, WS - West Sulawesi.

rial are age-coded using constant sinking velocities following Hafkenscheid et al. (2006) and Zahirovic et al. (2012), and assuming near-vertical sinking of slabs following Van Der Meer et al. (2010). Two end-member slab sinking scenarios are applied, with a stratified mantle with 3.0 and $1.2 \mathrm{~cm} \mathrm{yr}^{-1}$ sinking rates in the upper and lower mantle, respectively, compared to a whole mantle sinking rate of $1.4 \mathrm{~cm} \mathrm{yr}^{-1}$ (Fig. 8). Although the assumptions of constant sinking velocity and vertical sinking of slabs are an oversimplification, the age-coding technique offers a first-order insight to the subduction history, which we limit to the Cenozoic due to the complexity of slab sinking and advection in the mantle (Zahirovic et al., 2012). The P-wave model of Li et al. (2008) incorporates stations from the Chinese Seismograph Network with global data collated by Engdahl et al. (1998), resulting in well-resolved slabs related to circum-Asian subduction zones. The GyPSuM S-wave model from Simmons et al. (2009) was used (Supplement Fig. A7), in addition to the $\mathrm{P}$-wave model, to help interpret the subduction histories due to the better sampling of the mantle beneath oceanic regions and the Southern Hemisphere in order to avoid the landcoverage bias of P-wave models (Figs. 9 and 10). Positive 

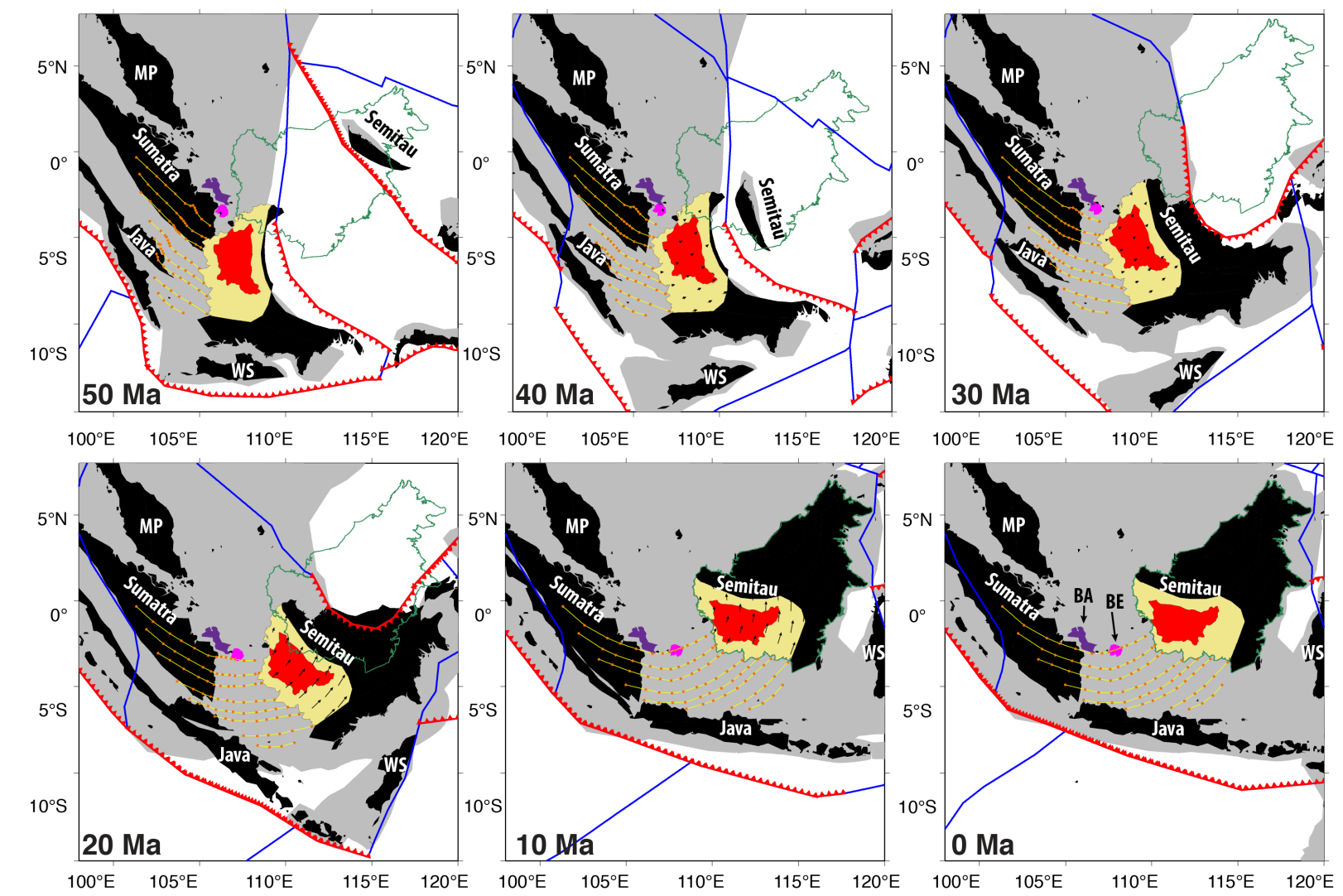

Fig. 7. The curved lineaments on the Sunda Shelf have been proposed by Hutchison (2010) to represent evidence of oroclinal bending of the continental promontory. We digitize these curvatures from the vertical gravity gradient (Fig. 4) and use the lineaments to derive an oroclinal bending model for Sundaland. We partition the counterclockwise rotation of Borneo from 50 to 10 Ma following evidence of rifting in the Java Sea, and partition $50^{\circ} \mathrm{CCW}$ rotation of Borneo from 25 to $10 \mathrm{Ma}$ following the paleomagnetic constraints provided by Fuller et al. (1999). Not only does the oroclinal bending model restore the generally north-south strike of the east Asian active margin in the Cretaceous, it can also be used to restore the position of Belitung (Billiton) Island to be adjacent to Bangka Island, and hence restoring the Mid- to Late Triassic volcanic arc related to the Southeast Asian tin belt. Plate boundaries (MORs/transforms - blue, subduction zones - red) are plotted in a Sumatra-fixed reference frame. The Borneo core (yellow) is largely comprised of the Schwaner Mountains and related granitoids (red), which is used to sample the velocity field of Borneo's motion relative to Sundaland. The positions of Borneo from Lee and Lawver (1995) are shown for comparison (green outline). See Supplement B for detailed steps for deriving the oroclinal bending model for Sundaland. BA - Bangka Island (violet), BE - Belitung (Billiton) Island (magenta), MP - Malay Peninsula, WS - West Sulawesi.

seismic velocity anomalies exceeding $0.2 \%$ in P-wave models are assumed to represent thermally perturbed mantle from subducted slabs, following the assumptions made by Van der Voo et al. (1999).

\subsection{Oroclinal bending of Sundaland and the rotation of Borneo}

Paleomagnetic data collected from Sundaland indicate that Borneo, Sumatra and the Malay Peninsula were likely positioned in near-equatorial latitudes since the Cretaceous (Haile et al., 1977). Paleomagnetic studies have also identified differential rotation between Borneo and the rest of Sundaland (Schmidtke et al., 1990; Fuller et al., 1999) and a rotation of Borneo up to $108^{\circ} \mathrm{CCW}$ relative to stable Eurasia since the Cretaceous (Schmidtke et al., 1990). The de- tailed paleomagnetic study of Fuller et al. (1999) indicates a $90^{\circ} \mathrm{CCW}$ rotation of Borneo in the Mesozoic, of which up to $\sim 50^{\circ} \mathrm{CCW}$ rotation occurred since $25 \mathrm{Ma}$ (Fuller et al., 1999). This counterclockwise rotation of Borneo relative to stable Eurasia has been flagged as a contradiction to the extrusion tectonic model (Schmidtke et al., 1990) proposed for Southeast Asia (i.e., Indochina) by Tapponnier et al. (1982), which requires up to $40^{\circ} \mathrm{CW}$ rotation of Indochina and related blocks (including Sundaland). As compelling evidence exists for dominant sinistral offsets along the Red River fault of $\sim 300$ to $500 \mathrm{~km}$ associated with the extrusion of Indochina (Tapponnier et al., 1990; Leloup et al., 2001, 2007; Hall, 2002), successive paleomagnetic studies have also robustly indicated a strong CCW rotation of Borneo. However, if Borneo rotated so significantly relative to Sundaland, then the motion requires transform faults accommodating relative 

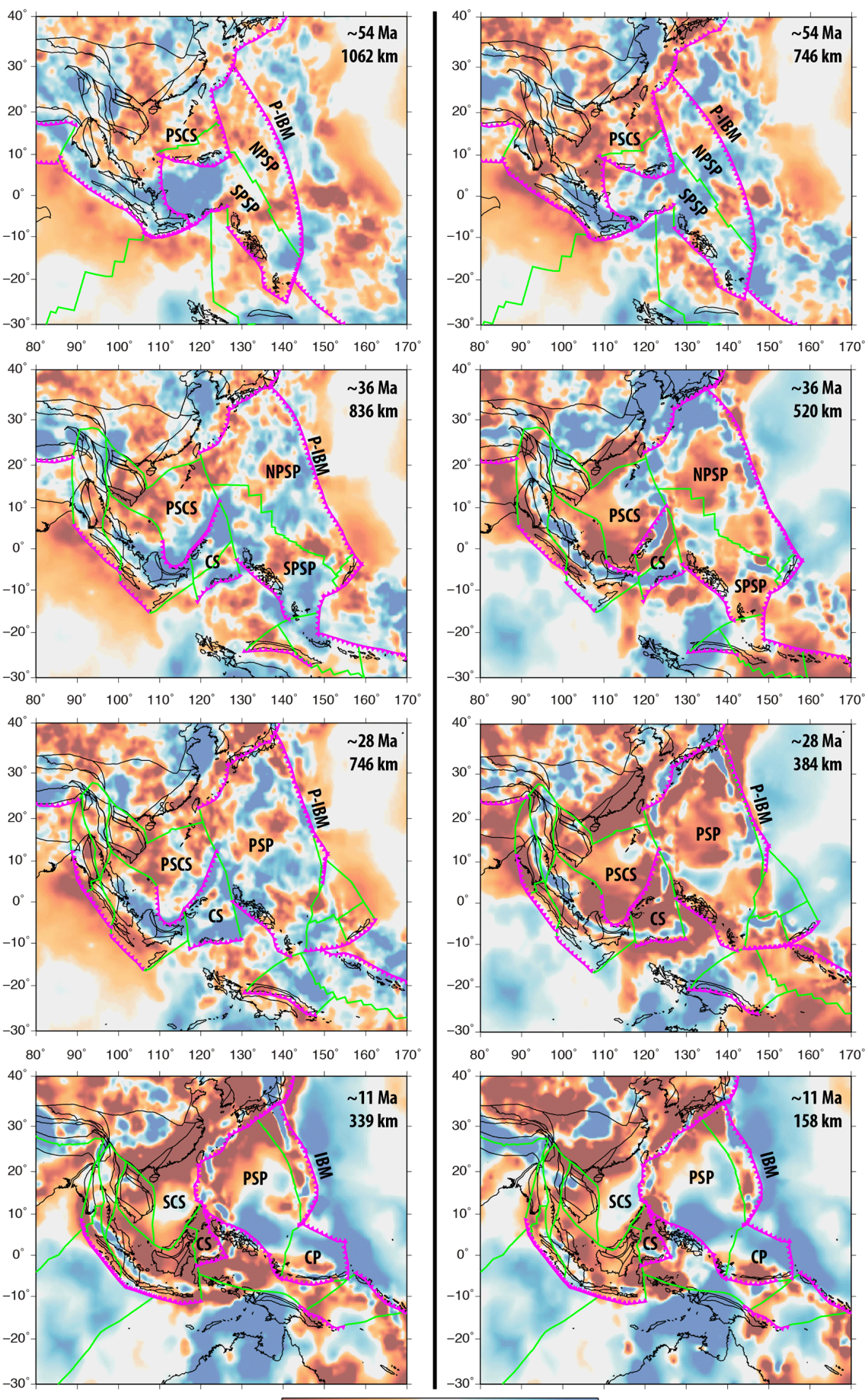

Sinking Rate Scenario 1

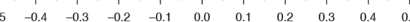

Velocity Perturbation (\%)

Sinking Rate Scenario 2

Fig. 8. Plate reconstructions superimposed on age-coded depth slices of MIT-P (Li et al., 2008) seismic tomography with two end-member sinking rate scenarios. Scenario 1 (left) applies a 3 and $1.2 \mathrm{~cm} \mathrm{yr}^{-1}$ sinking rate of slabs in the upper and lower mantle, respectively, following Zahirovic et al. (2012). Scenario 2 (right) applies a whole-mantle slab sinking rate of $1.4 \mathrm{~cm} \mathrm{yr}^{-1}$ as a low sinking rate endmember. The longitudinal position of the Philippine Sea Plate (PSP) is calibrated to the location of the slab material to coincide with the modeled subduction zone geometries. In addition, convergence along the Australian and Pacific segments was preserved to minimize trench advance, and account for the rollback of the Pacific slab and coupling to the Izu-Bonin-Mariana (IBM) Arc resulting in the opening of the Shikoku and Parece Vela basins. Reconstructed present-day coastlines (black) and plate boundaries (MORs/transforms - green, subduction zones - magenta) are plotted for reference. CP-Caroline Plate, CS - Celebes Sea, SCS - South China Sea, PSCS - proto-South China Sea, NPSP - northern Philippine Sea plate, SPSP - southern Philippine Sea plate, (P-) IBM - (proto-)Izu-Bonin-Mariana Arc. 
motion between Borneo and Sundaland, or alternatively the rotation is a manifestation of internal continental deformation of the Sundaland continental promontory. The model of Rangin et al. (1990) invokes rifting between Java and Borneo accommodated by a number of curved transform faults on the Sunda Shelf since the Eocene. The orientations of these transforms were based on the projection of small circles resulting from the opening of the South China Sea into the Sunda Shelf. These lineaments, much like in the Rangin et al. (1990) model, invoke some transform motion and accompanying internal deformation of continental crust that accommodated oroclinal bending of Sundaland (Hutchison, 2010). These arcuate structures are similar to the curvatures of the Natuna and Anambas Cretaceous volcanic arcs (Fig. 6), and the Mid- to Late Triassic granitic arc from the tip of the Malay Peninsula running eastward and north of Sumatra into Bangka and Billiton islands. Importantly, Hutchison (2010) used observations from satellite data to infer the continuity of the curved lineaments on the Sunda Shelf and the Java Sea.

We extend this approach and show that parallel arcuate lineaments are clearly observed in gravity anomalies of Sundaland, for instance in the 1-minute free-air gravity anomaly grid from the World Gravity Map (Balmino et al., 2012). Due to the high topographic relief of Borneo and other parts of Sundaland, and the necessity to track crustal fabric between emergent and submerged continental regions, we prefer to use the Bouguer anomaly model (Fig. 4) from the World Gravity Map to expose the tectonic fabric of Sundaland. We band-pass-filtered the Bouguer anomalies (Fig. 4a) to highlight large-scale features, and derived tilt angle derivatives (Fig. 4b) and vertical gravity gradients (Fig. 4c). The curved lineaments were used as guides (Figs. 4d, 7 and Supplement Fig. B1) to model the oroclinal bending of Sundaland. We assume that at some time in the past the curved lineaments were largely straight, much like those observed in north-western Sumatra. We assume that most of the oroclinal bending occurred in south-eastern Sumatra, the Java Sea and Borneo, where the concavity is the greatest, allowing us to keep northwest Sumatra fixed. Lines normal to the curved structures are digitized in a grid pattern from central Sumatra to the northern Java Sea (Fig. 4d). A rotation hierarchy is created for GPlates where the "normal guides" each move successively relative to their western neighbor, while north-western Sumatra is held fixed as the anchor terrane (Supplement B, Supplement Fig. B1). This curved grid can therefore be used to restore the Sundaland Orocline much like straightening the bellows of a musical accordion (see Supplement B).

Since the Sunda Shelf between western Borneo and the Malay Peninsula records very little compression or mountain building (Daly et al., 1991), we assume that only extension or minimal compression can be accommodated on the Sunda Shelf since the Eocene. The "normal guides" (Fig. 4d, black) are rotated about a pole near the northern vertex of each normal guide to ensure no compression is implied going forward in time, and each normal guide is rotated inter- actively to derive finite Euler rotations in GPlates as to create a visual best fit with the straight portion of the Sunda lineaments. Applying the accordion analogy, at this point the bellows are parallel to one another, resulting in lineaments that are largely straight. However, minor kinks in the restoration are inevitable largely because our oroclinal bending model is a simplification of a continuum of processes resulting in continental deformation across the entire Sunda Shelf. The rotations derived from undoing the curvature of the structural fabric are then partitioned between the onset and until the end of oroclinal bending. These timings are not well constrained, but end-member timings have been applied. Our preferred model invokes the onset of oroclinal bending from $\sim 50 \mathrm{Ma}$, constrained by the onset of rifting in the Java Sea basins (Doust and Sumner, 2007) that we interpret as the onset of internal continental deformation resulting from oroclinal bending. The age-coded positive seismic velocity anomalies (interpreted as slabs) also support that the Java-Sunda arc was largely linear at $\sim 50 \mathrm{Ma}$ (Fig. 8). Oroclinal bending likely ceased by $\sim 10 \mathrm{Ma}$, which corresponds to the end of Borneo rotation interpreted from paleomagnetic studies (Fuller et al., 1999), and is supported by the onset of basin inversion episodes in the Java Sea by $\sim 13 \mathrm{Ma}$ (Doust and Sumner, 2007) that indicate the end of an extensional regime on the Sunda Shelf. The paleomagnetic investigation by Fuller et al. (1999) also indicates that up to $51.8 \pm 3.7^{\circ} \mathrm{CCW}$ Borneo rotation occurred after $\sim 25 \mathrm{Ma}$ based on the age of volcanic intrusions. Our model complies with these requirements, and therefore we partition $50^{\circ}$ of $\mathrm{CCW}$ rotation of Borneo between 25 and $10 \mathrm{Ma}$ (Table 4, Fig. 7).

\section{Plate tectonic model}

An attempt has been made to present the plate motion model regionally and chronologically. We first document the rifting and collision history related to the growth of Southeast Asia, marked by major terrane boundaries in southern Eurasia and SE Asia (Fig. 1) where consecutive Tethyan Ocean basins were consumed (see reviews by Şengör et al., 1988; Acharyya, 1998; Hutchison, 1989; and Metcalfe, 1994). The cyclicity of Gondwanan terrane detachment is complemented by the establishment of intra-oceanic subduction preceding many of the accretion events, including the Permian backarc basin forming the Sukhothai Zone (Metcalfe, 2011; Sone et al., 2012) associated with the closure of the Paleo-Tethys, and the Kohistan-Ladakh (Burg, 2011) intra-oceanic subduction systems of the Meso- and Neo-Tethys (Aitchison et al., 2000). That is why the present-day intra-oceanic subduction systems in the west Pacific (including the Izu-BoninMariana and Tonga-Kermadec arcs) are often invoked as analogues for the intra-oceanic history of the Tethyan realm. On the Sundaland continental promontory, the southwest Borneo core has previously been invoked as a continuation of the Malay Peninsula and Sumatran terranes with Pale- 


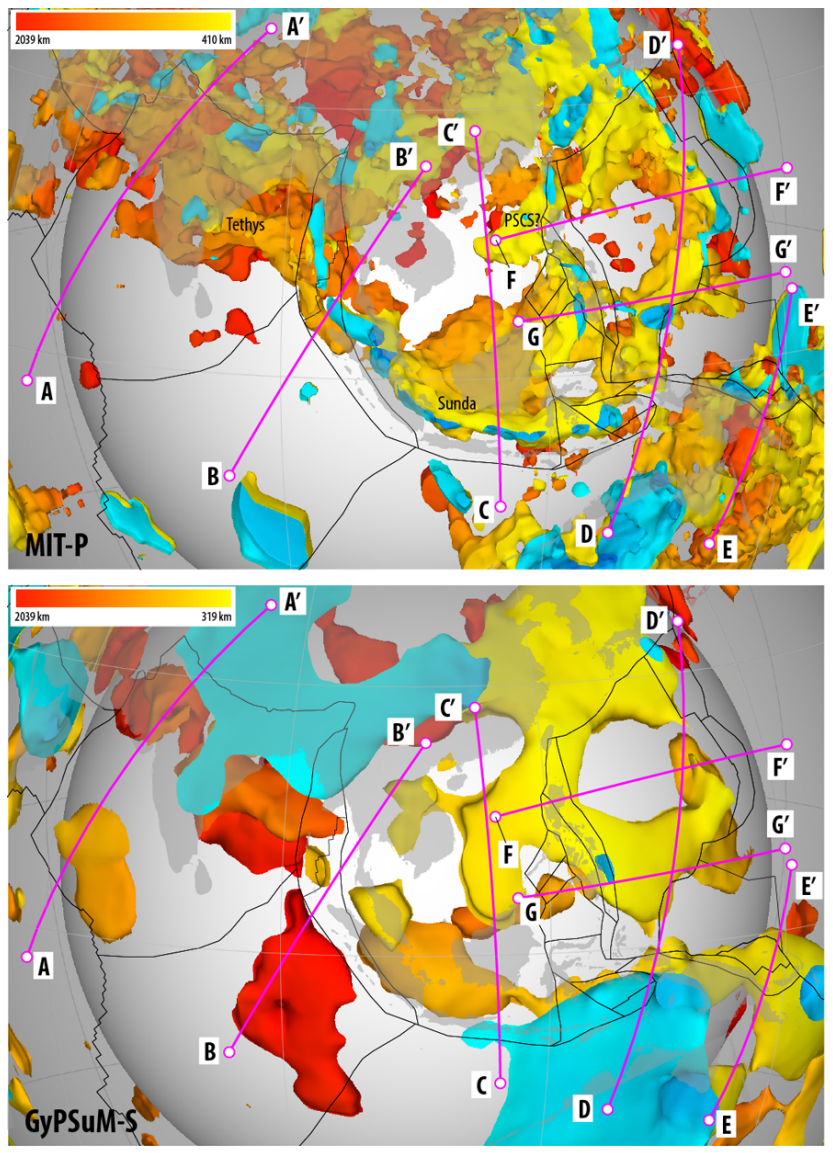

Fig. 9. 3-D visualization of $+0.2 \%$ seismic velocity anomaly isosurfaces in MIT-P (top) and $+0.9 \%$ seismic velocity perturbation in GyPSuM-S (bottom) models. Profiles A to G represent the vertical profiles (see Fig. 10) that capture the convergence and subduction histories of the region since the Cretaceous. Present-day coastlines are translucent grey shades, and present-day plate boundaries are translucent black lines. Slab volumes are colored by their depth, while the light blue color represents the interior surface of these slabs. PSCS - proto-South China Sea slab.

ozoic and Mesozoic metamorphosed basement intruded by melts derived from subduction of proto-Pacific oceanic crust in the Cretaceous (Katili, 1981; Charvet et al., 1994). However, the recent models of Metcalfe (2011) and Hall (2011, 2012) argue for a Late Jurassic-Early Cretaceous origin of the Borneo core from northwest Australia. We present an alternative scenario for the evolution of the Sundaland core in the context of plate reconstructions linking the transfer of terranes and the evolution of intra-oceanic subduction zones in the Tethyan and proto-Pacific domains.

\subsection{Latest Jurassic rifting of terranes from northern Gondwana}

Both Metcalfe (2011) and Hall (2012) propose that the latest Jurassic-Early Cretaceous rifting from northern Australia and New Guinea consisted of the southwest Borneo core, East Java and West Sulawesi (i.e., Argoland), with the NeoTethys opening through back-arc spreading along northern Gondwana. The models also invoke a simultaneous northdipping intra-oceanic subduction zone in the India-Eurasia segment of the Tethys as the "Incertus Arc" (Hall, 2012). In these models, and the model of Morley (2012), the southwest Borneo core docks to Sundaland along a transform margin, presently the Billiton Depression (Figs. 2 and 5), to the east of Sumatra by $\sim 110 \mathrm{Ma}$. The driving mechanism for anchoring southwest Borneo to Sunda along a transform rather than accreting to eastern South China is not explained. In these models, East Java-West Sulawesi accrete to the southwest Borneo core by $\sim 90 \mathrm{Ma}$ through short-lived south-dipping subduction along northern West Sulawesi. In the models of Metcalfe (2011) and Hall (2012), the LuconiaDangerous Grounds continental block (presently underlying the Sarawak Basin) accretes to northern Borneo soon afterwards in the Cretaceous, which is disputed by Morley (2012).

Our preferred scenario invokes the onset of rifting along northern Gondwana in the latest Jurassic to Early Cretaceous (Fig. 11a), propagating westward (Audley-Charles et al., 1988; Cullen and Pigott, 1989) along New Guinea and into the NW Australian shelf (Fig. 12b). South Sulawesi, easternmost Borneo, Mangkalihat and portions of East Java are considered to be fragments that likely originated on the New Guinea or Argo Abyssal Plain margin. We model seafloor spreading along northern Gondwana (New Guinea and northwest Australian shelf) from $\sim 155 \mathrm{Ma}$ (Fig. 12), as supported by a basaltic dyke and microgabbro associated with nearby pillow basalts on West Sulawesi (Figs. 1 and 2) that have an age range of 158-137 Ma (Polvé et al., 1997). Shallow marine sandstones of Late Jurassic age in the Bantimala Complex on West Sulawesi (Wakita, 2000), along with Jurassic-age ammonites, gastropods and brachiopods (Fig. 3) in the Paremba Sandstone (Sukamoto and Westermann, 1992; Wakita, 2000) support the onset of latest Jurassic seafloor spreading that we model. We acknowledge that the rifting may have initiated as early as $187 \mathrm{Ma}$ along northern New Guinea (Cullen and Pigott, 1989), determined from the oldest passive-margin sediments. However, we rely on the West Sulawesi mafics that are likely direct indicators of the onset of seafloor spreading. East Java and Borneo are treated as a continuation of West Sulawesi, as indicated by the present-day geometry of the Meratus and Luk-Ulo sutures on Sundaland. We infer that the rifting was initiated by the northward slab pull of the Meso-Tethyan seafloor subducting northward along the Sundaland core leading to microcontinent detachment from northern Gondwana (or at least the NW Australian shelf), following the mechanisms 

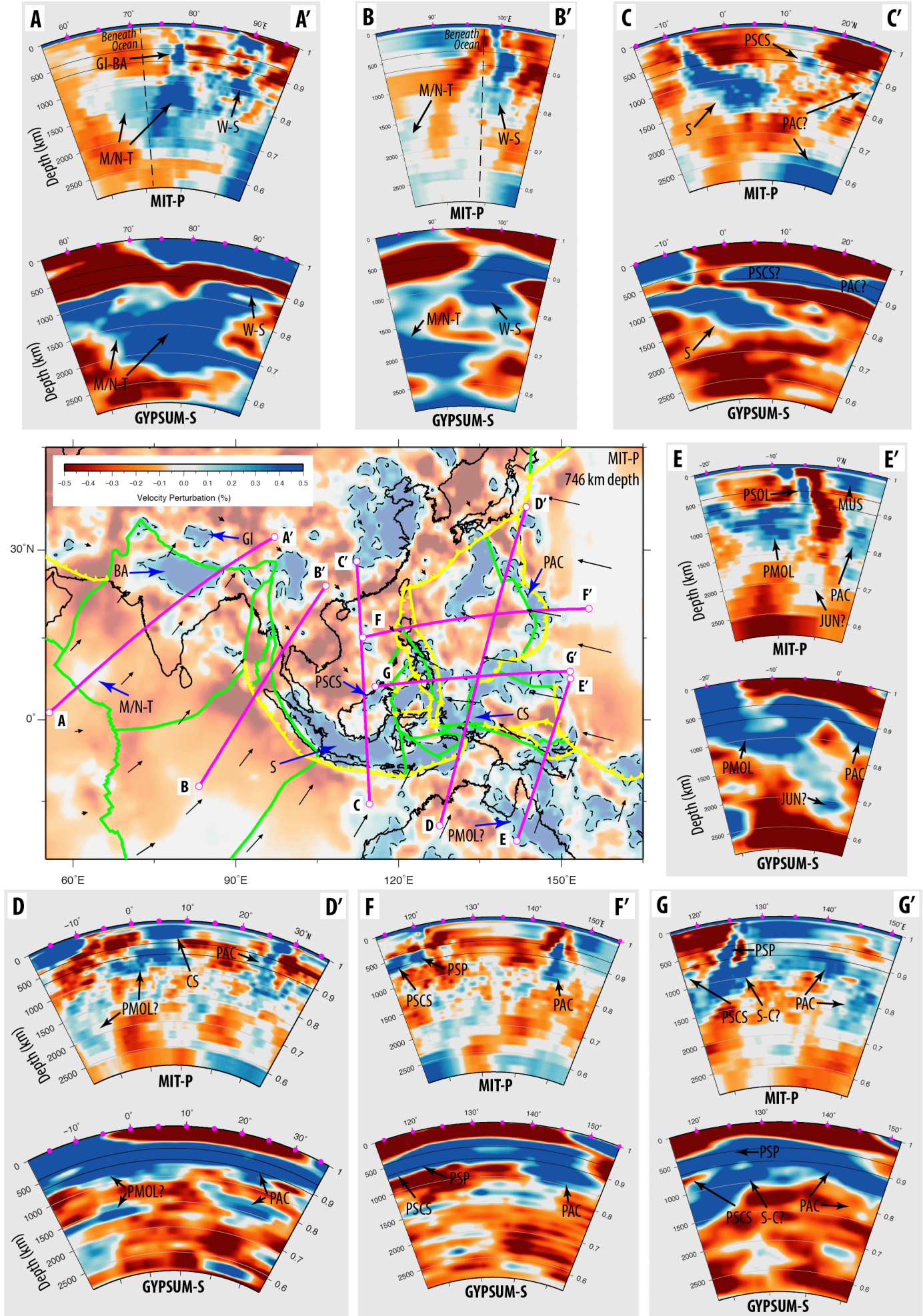

Fig. 10. Vertical sections from MIT-P (Li et al., 2008) and GyPSuM-S (Simmons et al., 2009) seismic tomography models along profiles A to $\mathrm{E}$ (magenta lines). The first-order differences between the $\mathrm{P}$ - and $\mathrm{S}$-wave models is that the amplitude of the positive seismic velocity anomalies significantly diminishes away from continental coverage (e.g., dashed lines in profiles A and B). A depth slice at $746 \mathrm{~km}$ from MIT-P is provided for reference with super-imposed present-day coastlines and plate boundaries. Interpreted slab sources are labeled: GI-BA = Greater India-Neo-Tethyan back-arc slab, M/N-T - Meso- and Neo-Tethyan slabs, W-S - Woyla-Sunda slabs, S - Sunda slab, PSCS - proto-South China Sea slab, PAC - Pacific slab, PMOL - proto-Molucca slab, PSOL - proto-Solomon slab, CS - Caroline slab, PSP - Philippine Sea Plate slab, S-C = Sulu-Celebes slabs. 

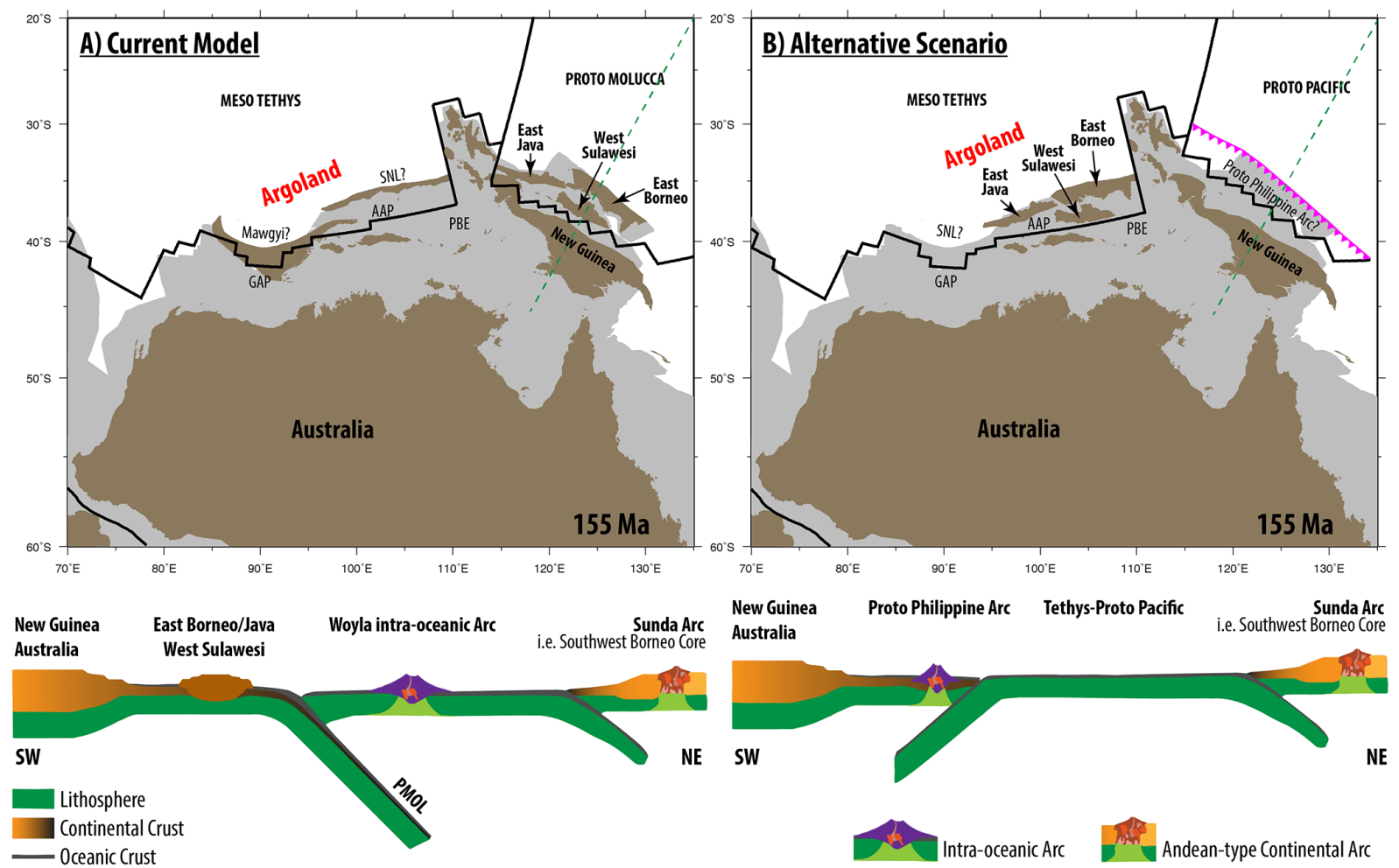

Fig. 11. End-member pre-rift scenarios along northern Gondwana during the latest Jurassic $(\sim 155 \mathrm{Ma})$ rift timing with a triple junction detaching the East Java, West Sulawesi, East Borneo and Mangkalihat from New Guinea driven by north-dipping subduction along the Woyla intra-oceanic arc representing the model implemented in this study (left). Alternatively, these blocks may have originated in the Argo Abyssal Plain (AAP), and a back-arc scenario may have existed along New Guinea (right), similar to the Incertus Arc proposed by Hall (2012). However, if this back-arc spreading did not detach continental blocks, then it may be the source for the proto-Philippine Arc. It is beyond the scope of this study to resolve whether the Mawgyi Nappes on West Burma or the Woyla Terranes on Sumatra contain microcontinental blocks, as it remains a continued source of controversy. We prefer the accretion of buoyant microcontinents in this region in order to account for the closure mechanism of the Woyla back arc in the Late Cretaceous. GAP-Gascoyne Abyssal Plain, PBE-proto-Banda Embayment, SNL - Sikuleh, Natal, Lolotoi and Bengkulu microcontinents. Schematic cross sections approximately follow dashed green line and are modified from Bouilhol et al. (2013). Not to scale.

described by Müller et al. (2001). The seafloor spreading on the NW Australian shelf created the proto-Banda Embayment, which also resulted in the abandonment of "paraautochthonous" continental fragments to form the Sula Spur (Audley-Charles et al., 1979; Hall, 2012; Norvick, 1979).

Although the seafloor spreading likely propagated from east to west along the margin, it is likely that a ridge-ridgeridge triple junction was required in the Meso- and NeoTethys to link and accommodate northwestward separation of continental fragments from the NW Australian shelf and the simultaneous rifting on the New Guinea margin. The strike of the NW Australian margin, representing the latest Jurassic rifting and subsequent seafloor spreading, is highlighted by the magnetic anomalies (Gibbons et al., 2013; Heine and Müller, 2005) and the reactivated structures on the continental shelf (Keep and Harrowfield, 2005) with a northeastsouthwest trending fabric. The New Guinea segment of the passive margin has not been preserved, but the outline of the stable part of the continent and the azimuth of reacti- vated structures of the Papuan Fold and Mobile belts (Gow and Walshe, 2005; Hill and Hall, 2003; Hill, 1991) have a bearing approximately $120^{\circ}$ from those on the NW Shelf (see Supplement A, Figs. A5-6). It is therefore kinematically incompatible to imply northwestward rifting from the NW Australian shelf and simultaneous northeastward rifting from the New Guinea margin without requiring a triple junction or a dense series of transform faults to accommodate a significant change in rifting directions. It is difficult to determine the longevity and exact nature of this triple junction as the seafloor has been completely subducted. However, we invoke the simplest tectonic scenario to propagate rifting from the New Guinea to the NW Australian margin. We model the eastern boundary of the Meso-Tethys as a transform that accommodates extension and progresses to seafloor spreading to become the third arm of the NeoTethyan triple junction (Fig. 12). We invoke the separation of microcontinental fragments (potentially now in the Mawgyi and Woyla Nappes) from the Argo Abyssal Plain us- 


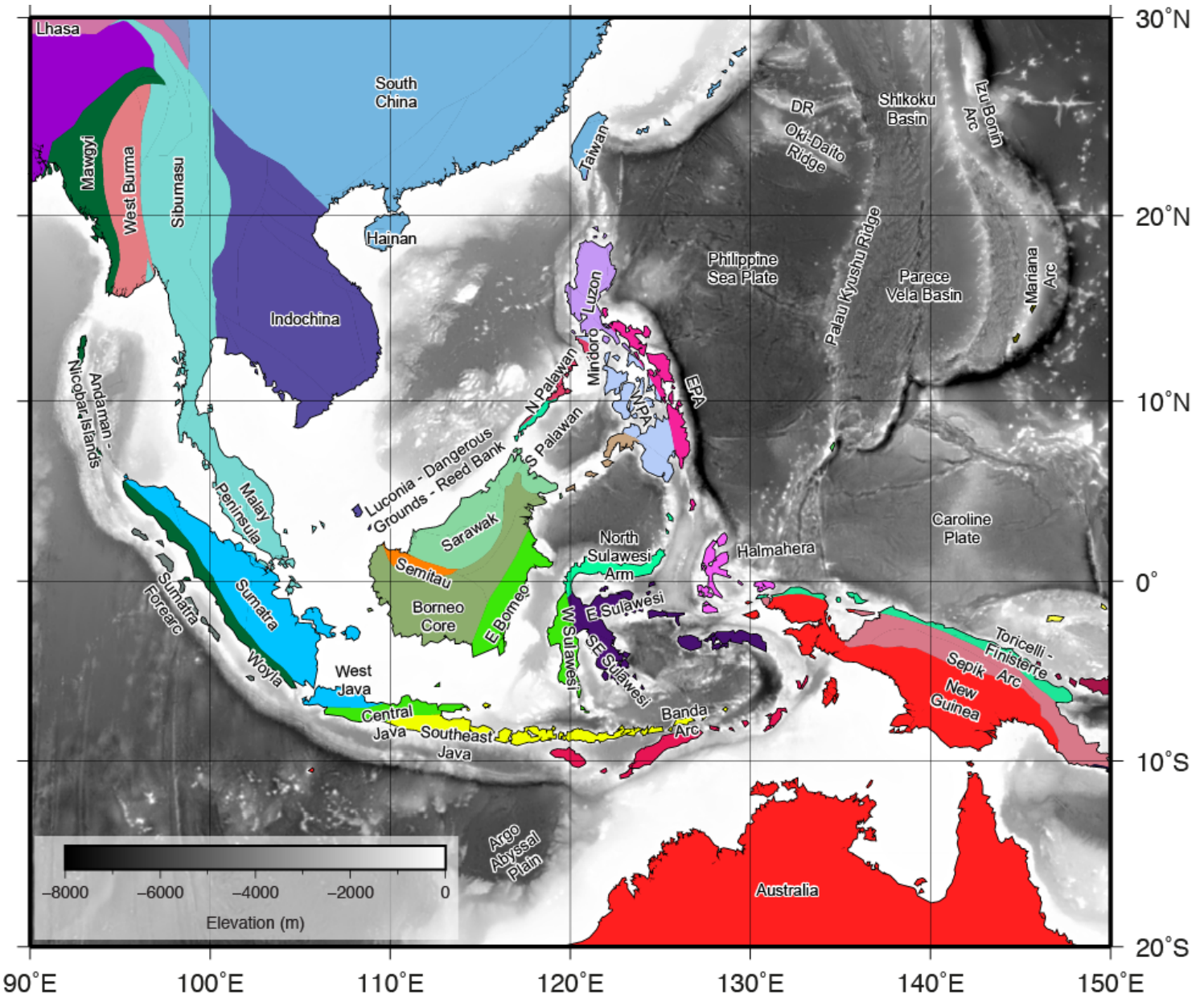

Fig. 12a. Present-day distribution of blocks and tectonic features (including oceanic basins, arcs and ridges) related to the long-term convergence of the Eurasian, Indo-Australian and Pacific plates. Tectonic elements are color-coded by their tectonic affinities. The colors can help track the motion of tectonic elements through time in Fig. 12b and the animation in the Supplement. Grey shading is ETOPO-1 bathymetry (Amante et al., 2009). DR - Daito Ridge, WPA - West Philippine Arc, EPA - East Philippine Arc.

ing the seafloor spreading model of Gibbons et al. (2012). Although the Mawgyi Nappe obscures the basement rock, we assume that a Gondwana-derived terrane that supplied Timor with sediment from the northwest as interpreted by Metcalfe (1996) underlies this sedimentary cover, and is a westward extension of the contemporaneous, although controversial, microcontinental fragments found in the Sikuleh, Natal and Bengkulu areas on the Sumatra margin (Barber and Crow, 2003; Morley, 2012). We follow the model of Gibbons et al. (2012) that invokes continental block detachment in the Argo Abyssal Plain at $\sim 155 \mathrm{Ma}$ (Figs. 11 and 12), and we assume that these blocks collide with the Woyla intraoceanic arc to drive the closure of the associated back-arc basin by the Late Cretaceous (Metcalfe, 2006). However, we acknowledge that East Java, West Sulawesi and Mangkalihat may have originated from the NW Australian margin rather than northern New Guinea (Fig. 11), as discussed in more detail below. Our kinematic model implies largely continu- ous subduction along the Sumatra and Java-Sunda trenches, with a $\sim 10 \mathrm{Myr}$ magmatic gap between $\sim 75$ and $65 \mathrm{Ma}$ that can be accounted for assuming impeded subduction during the accretion of the Woyla Arc and obduction of ophiolites onto Sumatra (Fig. 3).

Perhaps through their shared pedigree, the models of Metcalfe (2011), Hall (2012) and Morley (2012) argue for a leaky transform plate boundary (i.e., "I-A transform") approximately coincident with the continuation of the Ninetyeast Ridge (Fig. 1) in the Neo-Tethys to accommodate IndiaEurasia convergence between 90 and $45 \mathrm{Ma}$ without requiring subduction of the Australian plate along the Java-Sunda margin, which they argue does not record any significant volcanism during this time interval. Importantly, Hall (2012) rejects the possibility of any ridge intersections (namely the Wharton Ridge, Fig. 12b) with the Java-Sunda subduction zone and rejects the possibility of subduction along the eastern segment in the Neo-Tethys between 90 and $45 \mathrm{Ma}$. 

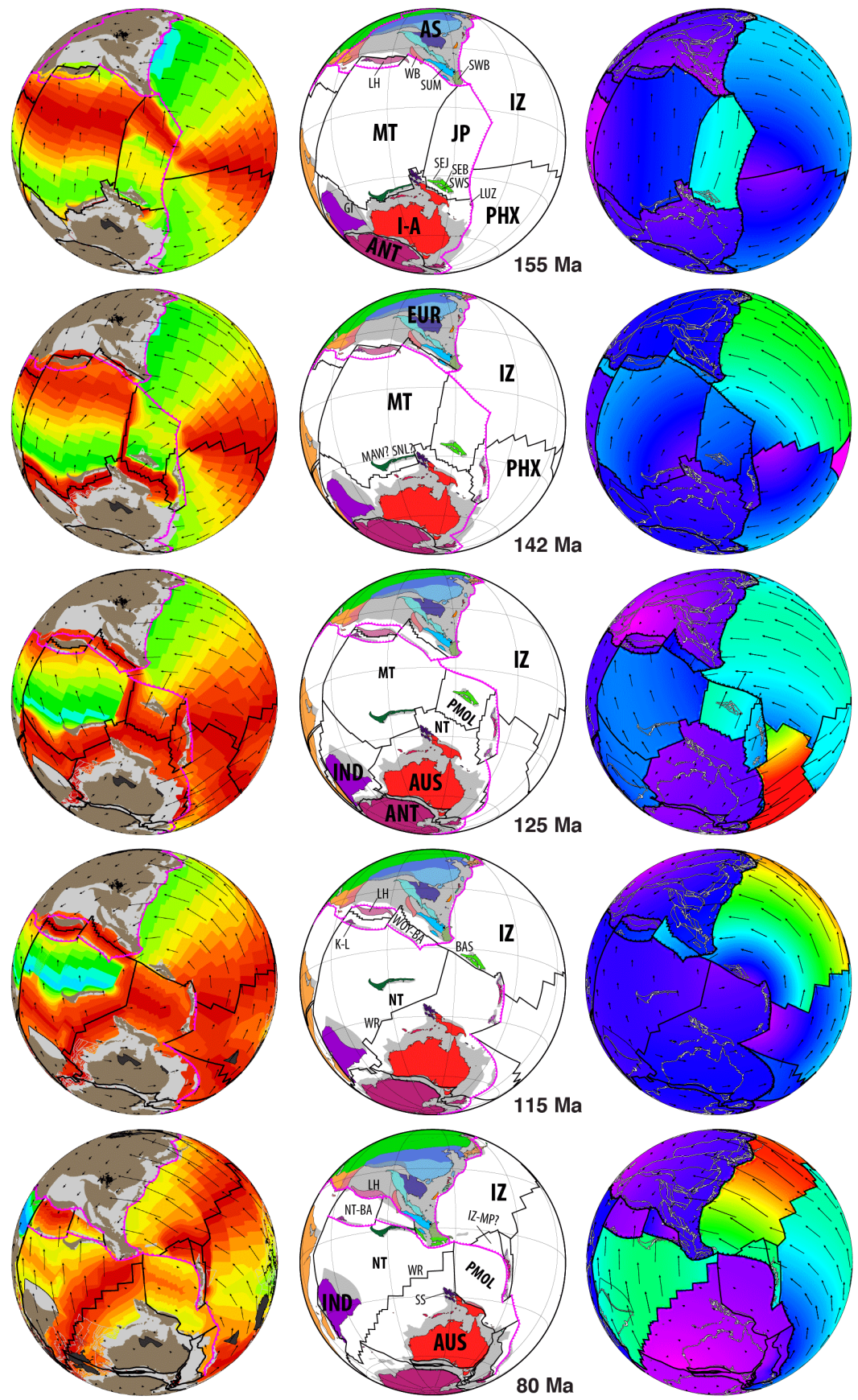

$\begin{array}{lllllllllllllll}0 & 20 & 40 & 60 & 80 & 100 & 120 & 140 & 160 & 180 & 200 & 220 & 240 & 260 & 280\end{array}$ Age of Oceanic Lithosphere (Myr)

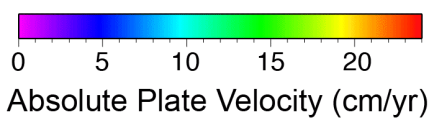

Fig. 12b. Plate reconstructions with colored blocks (middle), seafloor ages (left) and plate velocities (right). Northern Gondwana experiences a rifting event in the latest Jurassic ( $\sim 155 \mathrm{Ma}$ ), and we implement the detachment of Argoland continental fragments, easternmost Borneo, East Java, Mangkalihat and West Sulawesi at this time. The embryonic portions of the Philippine Arc are likely related to the easternmost portion of Tethyan seafloor spreading with supra-subduction affinities of latest Jurassic-Early Cretaceous volcanics. The intra-oceanic subduction system in the central Neo-Tethys (K-L, NT-BA), accommodating India-Eurasia convergence, also becomes established in the Early Cretaceous. Gondwana-derived continental fragments begin to collide with the intra-oceanic subduction system in the mid-Cretaceous, and suture to Sundaland by $\sim 80 \mathrm{Ma}$ and to West Burma/Sumatra by $\sim 70 \mathrm{Ma}$. A pre-existing transform on the eastern margin of the Philippine Sea plate converts to a west-dipping subduction zone consuming Pacific crust by $\sim 55 \mathrm{Ma}$. Continued convergence of Indo-Australia with Eurasia results in the contact of the Sula Spur with the Java-Sunda trench by $\sim 25 \mathrm{Ma}$. The Sepik composite terrane docks to New Guinea by $27 \mathrm{Ma}$, followed by accretion of the Prince Alexander-Finisterre-Torricelli arc from $6 \mathrm{Ma}$. Subduction zones - magenta teethed lines, transforms/MORs - black lines, continental extent-grey, large igneous provinces (LIPs) - dark grey. AS - Asian Plate, EUR - Eurasian Plate, MT-Meso-Tethys, NT - Neo-Tethys, JP-Junction Plate, PMOLproto-Molucca Plate, IZ - Izanagi Plate, PHX - Phoenix Plate, I-A - Indo-Australian Plate, ANT - Antarctic Plate, AUS - Australian Plate, IND - Indian Plate, GI - Greater India, LH - Lhasa, WB - West Burma, SUM - Sumatra, SWB - southwest Borneo, SEJ-southeast Java, SEB - southeast Borneo, SWS - southwest Sulawesi, LUZ-Luzon, N-S/PSPnorthern/southern Philippine Sea plate, SS - Sula Spur, WR - Wharton Ridge, NT-BA - Neo-Tethyan back arc, K-L - Kohistan-Ladakh, WOY-BA - Woyla back arc, BAS - Barito Sea, MAW - Mawgyi microcontinent, CAP-Capricorn Plate, SNL-Sikuleh, Natal, Lolotoi and Bengkulu microcontinents, IZ-MP? - Izanagi microplate?, CP-Caroline Plate, SOL-Solomon Sea plate. Digital animations are included in the Supplement (orthographic projection with center co-ordinate $15^{\circ} \mathrm{S}, 110^{\circ} \mathrm{E}$ ). 

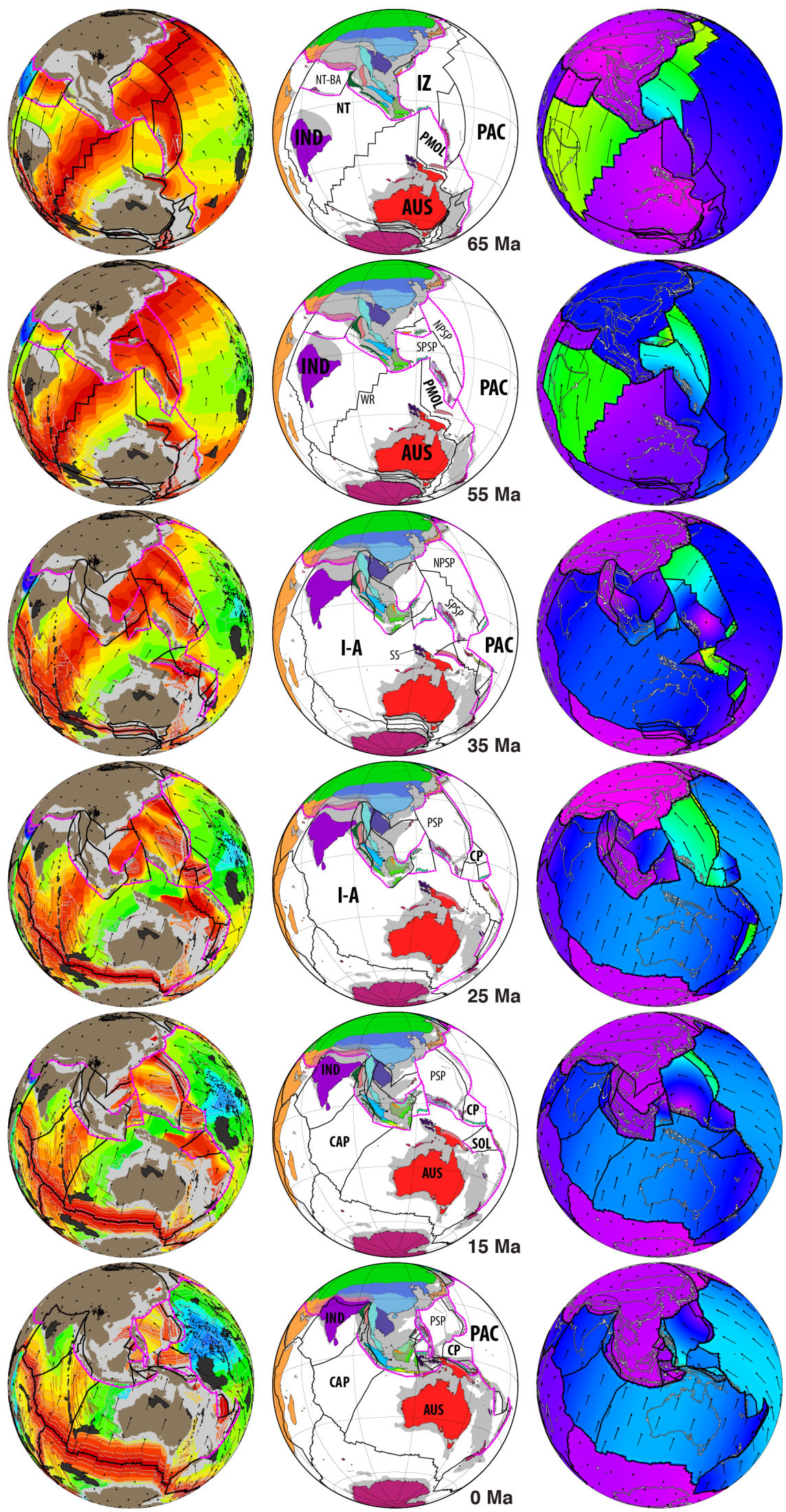

Fig. 12b. Continued. 
Instead, the model of Hall (2012) requires that up to $500 \mathrm{~km}$ of the Australian plate subducts beneath the Indian Plate, or vice versa, between 75 and $55 \mathrm{Ma}$. This is likely a result of the choice of Euler rotations representing Australia-IndiaAntarctica breakup, as well as the effects of plate circuits and absolute reference frames. The Hall (2012) model uses motions of India and Australia based on the model of Royer and Sandwell (1989) that did not have the benefit of marine magnetic anomaly data collected over the last 2 decades, while our model is based on compilations of more modern data and re-interpretations of marine magnetic anomalies (Gibbons et al., 2013; Müller et al., 2008) and the consideration of continental stretching and deformation during initial Australia-Antarctica rifting (Williams et al., 2011). As a result, our model does not require any convergence between the Indian and Australian plates between 75 and $55 \mathrm{Ma}$, and instead seafloor spreading is accommodated on the now-extinct Wharton Ridge rather than the convergence required by the Hall (2012) model along the leaky I-A transform that cuts across the pre-existing tectonic grain of oceanic lithosphere. The model of Seton et al. (2012) and earlier incarnations, such as those presented by Gurnis et al. (2012) and Whittaker et al. (2007), portray continuous subduction of Neo-Tethyan oceanic crust along Java-Sunda, with the Wharton Ridge intersecting this margin in the early Eocene (Fig. 12b). Volcanic arc rocks on Sumatra have been documented by Cobbing (2005) with an age range of 264 to $75 \mathrm{Ma}$ (namely the Sibolga Batholith in North Sumatra), with a subsequent population whose ages range from $\sim 65 \mathrm{Ma}$ to recent times (Bellon et al., 2004), consistent with the synthesis of Sumatran volcanics by McCourt et al. (1996). Such data suggest that a magmatic gap along the Sumatra and Java-Sunda margin may have existed between $\sim 75$ and 65 Ma (Fig. 3), but not for the entire duration between 90 and $45 \mathrm{Ma}$ as argued by Hall (2012). Subduction along the Java-Sunda trench in the Cenozoic established a volcanic arc, leading to the continued accretionary growth of eastern Java since Eocene times (Smyth et al., 2007).

\subsection{Cretaceous plate boundary configurations linking the Tethys and proto-Pacific}

Reconstructing the proto-Pacific is notoriously difficult due to the lack of preserved seafloor with reconstructions relying on assumptions of symmetrical seafloor spreading where single flanks of the spreading system are preserved (Seton et al., 2012) or evidence of compression or extension that may be recorded in the geology of the overriding plate (Hilde et al., 1977; Johnston and Borel, 2007; Li et al., 2012; Ruban et al., 2010). Linking the motions of the Pacific Plate to the remaining plate circuit has also been a considerable challenge due to the added complexity of moving hotspots (O'Neill et al., 2005), ridge capture of plumes and the deflection of plume conduits resulting from mantle advection (Christensen, 1998; Tarduno et al., 2009), and the lack of preserved seafloor spreading linking the Pacific to the Indo-Atlantic plate circuit (Seton et al., 2012).

Two end-member scenarios exist that describe the link between the easternmost Tethys and western Panthalassa. The model of Seton and Müller (2008) and Seton et al. (2012) requires a westward-dipping subduction zone that defines the boundary between Panthalassa and the Junction Plate, an isolated seafloor spreading system forming the easternmost Tethyan domain. Alternative scenarios propose a continuation of the proto-Pacific mid-ocean ridge system into the Tethyan oceanic basins (Audley-Charles, 1988; Hilde et al., 1977; Ben-Avraham, 1978). However, the westwarddipping subduction in the Cretaceous along eastern Asia (Seton et al., 2012; Hall, 2002; Hilde et al., 1977), implying westward motion of the proto-Pacific seafloor, is kinematically incompatible with northward-directed subduction of Tethyan seafloor along southern Eurasia without requiring a stable mid-oceanic ridge triple junction or a convergent boundary between the two tectonic domains. A midoceanic ridge triple junction would require numerous southward ridge jumps to maintain seafloor spreading across the proto-Pacific-Tethys oceanic gateway. We follow the model of Seton et al. (2012) where convergence between the protoPacific and the Meso-Tethys is accommodated largely by westward-dipping subduction along the Late Jurassic Junction Plate in the eastern Tethys that formed as a back arc along northern New Guinea (Monnier et al., 2000) but was being subducted northward due to a reversal in subduction polarity by $155 \mathrm{Ma}$ as represented in our model (Fig. 12b).

Our Meso-Tethyan triple junction in the easternmost Tethys remains active between 155 and $115 \mathrm{Ma}$, with the north-south striking spreading arm abandoned when the West Sulawesi-East Java terrane collided with the fore arc of an eastward continuation of the intra-oceanic Woyla subduction zone. This collision timing between the West SulawesiEast Java terrane with the intra-oceanic subduction zone, consuming the proto-Molucca Plate beneath the Izanagi Plate, is determined from the peak of ultrahigh P/T metamorphism related to the closure of the Barito Sea (Wakita, 2000) (BAS, Fig. 13b). Rather than invoking the accretion of the southwest Borneo core to Sundaland at $\sim 110 \mathrm{Ma}$ as argued by Hall (2012), we prefer the scenario of easternmost Borneo, South Sulawesi, Mangkalihat and East Java colliding with an intra-oceanic island arc following the $\mathrm{K}-\mathrm{Ar}$ dated $\sim 120-110 \mathrm{Ma}$ metamorphic belts that are associated with dismembered ophiolites, stretching along the southern Cretaceous paleo-margin of Sundaland (Parkinson et al., 1998) and outcropping in the Luk-Ulo and Meratus sutures (Fig. 1 and Supplement Fig. A1). The Meratus Ophiolite was likely obducted between $\sim 100$ and $93 \mathrm{Ma}$, in the Cenomanian (Yuwono et al., 1988), and final closure and suturing of the Barito Sea along the southeastern margin of the southwest Borneo core occurs by $80 \mathrm{Ma}$ based on the U-Pb dated zircons in fore-arc sandstones (Clements and Hall, 2011; Wakita, 2000). The collision of the Gondwana-derived terranes with 
the Southeast Asia margin is asynchronous, with progressive accretions westward. Intra-oceanic collisions occur by $100 \mathrm{Ma}$ in the Woyla segment (Fig. 12b), associated with the obduction of the Chin Hills and Naga ophiolites (Morley, 2012), with renewed subduction and fore-arc emplacement likely forming the Andaman Ophiolite at $95 \pm 2 \mathrm{Ma}$ in a suprasubduction zone setting (Pedersen et al., 2010). We invoke continuous north-dipping subduction of Tethyan oceanic crust following Guntoro (1999), to produce the large mid-mantle slabs interpreted in tomography (M/N-T, Figs. 9 and $10 \mathrm{a}-\mathrm{b})$ and previously described by Van der Voo et al. (1999). However, Morley (2012) invokes south-dipping subduction of Woyla back arc beneath Tethyan oceanic crust prior to collision of the continental fragments. We prefer continued north-dipping subduction of Tethyan crust to produce slab pull necessary for the northward motion of the IndoAustralian plates, emplace Late Cretaceous granites on West Burma (Mitchell et al., 2012), while following the trend of subduction polarities in the central Meso- and Neo-Tethys proposed in previous studies (Aitchison et al., 2000; Ali and Aitchison, 2008; Van der Voo et al., 1999).

\subsection{Intra-oceanic subduction in the Meso- and Neo-Tethys}

The evolution of the Neo-Tethyan subduction zone along southern Eurasia has been a source of continued controversy as to whether this margin was a long-lived Andean-type margin or whether it included back-arc opening and intra-oceanic subduction episodes (Aitchison et al., 2007; Aitchison et al., 2000; Zahirovic et al., 2012). Recent fieldwork has revealed remnants of Cretaceous intra-oceanic subduction in the Indus-Tsangpo suture zone (Aitchison et al., 2000; Davis et al., 2002; Ziabrev et al., 2004). However, plate motion reconstructions tend to differ in key areas, including (1) the subduction polarities, (2) the number of active subduction zones bounding southern Eurasia, and (3) the tectonic driving forces related to the opening and closure of the proposed back-arc basins. Previous studies argued for Shyok Suture (Karakoram-Kohistan) closure in the Late Cretaceous, between 102 and $75 \mathrm{Ma}$, well before the approach of India to the Eurasian margin (Molnar and Tapponnier, 1975; Petterson and Windley, 1985; Beck et al., 1995; Rowley, 1996; Bignold and Treloar, 2003) based on the review of Rehman et al. (2011). Subduction beneath Kohistan was interrupted between $\sim 95$ and $85 \mathrm{Ma}$, and was replaced by arc rifting (Burg, 2011), suggestive of a new pulse of back-arc generation in the Neo-Tethys at this time, much like the multi-phase back-arc generations in the Mariana Arc system on the eastern margin of the Philippine Sea plate (Sdrolias and Müller, 2006; Sdrolias et al., 2004). The cessation of magmatism by $\sim 61 \mathrm{Ma}$ on Kohistan and paleo-latitude estimates from paleomagnetic data led Khan et al. (2009) to conclude that India first collided with the Kohistan Arc. Such a scenario would require the Shyok Suture to be closed sometime in the early Eocene (Burg, 2011; Heuberger et al., 2007), much later than the established argument for Late Cretaceous suturing. A recent isotopic study by Bouilhol et al. (2013) of granitoids on Kohistan and Ladakh indicated that the leading edge of Greater India likely collided with this island arc at $50.2 \pm 1.5 \mathrm{Ma}$, while the Shyok Suture closed much later than previous estimates at $40.4 \pm 1.3 \mathrm{Ma}$, rather than in Cretaceous times.

The $\sim 85 \mathrm{Ma}$ event in the central Neo-Tethys is contemporaneous with other collisional events in the eastern Tethys, namely the collisions of Argoland (Mawgyi, Sikuleh and related blocks?) with the Woyla intra-oceanic arc, and the accretion of East Java and West Sulawesi terranes to Sundaland (Hall, 2011; Hall, 2012; Metcalfe, 2011; Morley, 2012). The Woyla terranes (Fig. 12b), which sutured to Sumatra in the Late Cretaceous displays both intra-oceanic subduction (Wajzer et al., 1991; Barber and Crow, 2003) and Gondwanaderived affinities (Metcalfe, 1996) and therefore suggests that intra-oceanic subduction extended further east of the IndiaEurasia convergence zone in the Meso- and Neo-Tethys. It has previously been suggested that the intra-oceanic subduction and related back arc were closed as a result of the collision of a number of microcontinents, including the Sikuleh, Natal, Lolotoi and Bengkulu blocks, with subsequent suturing to Sumatra (Acharyya, 1998; Metcalfe, 1996). However, the continental nature of these blocks has been reinterpreted to instead suggest an intra-oceanic island arc origin for these blocks (Barber and Crow, 2003; Wajzer et al., 1991). Existing models of northern Gondwana rifting episodes depict the detachment of Argoland in the Late Jurassic to close the Woyla (or Incertus) back arcs in the Late Cretaceous (Hall, 2012; Heine et al., 2004; Metcalfe, 2011). However, these models disagree both on the block's origin and destination (Table 3), with contrasting present-day candidates including West Burma (Heine and Müller, 2005) or southwest Borneo and East Java (Hall, 2012; Metcalfe, 2011). Although it is possible that West Burma originated from the NW Australian shelf, no evidence is available to link West Burma to northern Gondwana in the Late Jurassic (Morley, 2012; Metcalfe, 1996). We tentatively follow the interpretation of Metcalfe (2011) that places West Burma in the proximity of Indochina in the Paleozoic, based on reported Cathaysian fusulinids west of the Sagaing Fault (Morley, 2012), and stress that further study is required to better understand the role of West Burma in Southeast Asian tectonic growth. In particular, if West Burma was on the Eurasian margin in the Jurassic and earlier, evidence for arc volcanism related to Tethyan subduction will need to be accounted for on this margin. Following the model of Gibbons et al. (2012), we implement the accretion of Argoland microcontinental fragments to the Burma and Sumatra portion of the Woyla intra-oceanic arc. However, as discussed below, Argoland may have collided with Sunda rather than West Burma, meaning that East Java and easternmost Borneo may be alternative candidates for the enigmatic Argoland block. 
Table 3. The origin and present-day candidates for microcontinents that collided with the Neo-Tethyan intra-oceanic arc are controversial and vary substantially across published models. We acknowledge that the easternmost Borneo, Mangkalihat, East Java and West Sulawesi may have originated from either the Argo Abyssal Plain or the New Guinea margin. However, we do not believe that the southwest Borneo core rifted from northern Gondwana in the latest Jurassic with these blocks.

\begin{tabular}{|c|c|c|c|c|}
\hline Terrane & Tectonic origin & Accretion age & Accreted to & Reference \\
\hline \multirow[t]{2}{*}{ West Burma } & Argo Abyssal Plain & Triassic & Indochina & $\begin{array}{l}\text { Metcalfe (2011), } \\
\text { Hall (2012) } \\
\text { This study }\end{array}$ \\
\hline & Argo Abyssal Plain & Late Cretaceous & Sibumasu & $\begin{array}{l}\text { Metcalfe (1994), } \\
\text { Heine et al. (2004) }\end{array}$ \\
\hline \multirow[t]{2}{*}{ Mawgyi } & Intra-oceanic island arc & \multirow[t]{2}{*}{ Late Cretaceous } & \multirow[t]{2}{*}{ West Burma } & Mitchell (1993) \\
\hline & $\begin{array}{l}\text { Possibly underlain by Gondwana continental } \\
\text { fragments colliding with an intra-oceanic arc }\end{array}$ & & & This Study \\
\hline \multirow[t]{2}{*}{ Sikuleh, Natal, Lolotoi } & Intra-oceanic island arc & \multirow[t]{2}{*}{ Late Cretaceous } & \multirow[t]{2}{*}{ Sumatra } & Barber (2000) \\
\hline & Continental fragments & & & $\begin{array}{l}\text { Acharyya (1998), } \\
\text { Metcalfe (1996) }\end{array}$ \\
\hline \multirow[t]{2}{*}{ Southwest Borneo } & Argo Abyssal Plain & Late Cretaceous & \multirow[t]{2}{*}{ Sundaland } & $\begin{array}{l}\text { Metcalfe (2011), } \\
\text { Hall (2012) }\end{array}$ \\
\hline & Northern Gondwana & Early Permian & & This Study \\
\hline \multirow[t]{2}{*}{$\begin{array}{l}\text { Easternmost Borneo, } \\
\text { Mangkalihat, East Java } \\
\text { and West Sulawesi }\end{array}$} & Argo Abyssal Plain & \multirow[t]{2}{*}{ Late Cretaceous } & \multirow[t]{2}{*}{ Sundaland } & $\begin{array}{l}\text { Metcalfe (2011), } \\
\text { Hall (2012), } \\
\text { This Study }\end{array}$ \\
\hline & New Guinea & & & This Study \\
\hline
\end{tabular}

\subsection{The evolution of the Philippine Archipelago and Philippine Sea plate}

The east and west Philippine Archipelago (EPA and WPA, Fig. 12a), forming the western boundary of the Philippine Sea plate, is a mosaic of ophiolite exposures (Encarnación, 2004; Pubellier et al., 2004), active and extinct volcanic arcs and is dissected by the sinistral wrench Philippine Fault (Fig. 1) that has been active since at least $\sim 4 \mathrm{Ma}$ (Barrier et al., 1991). However, evidence for wrench faulting in the Late Cretaceous also exists, suggesting an older pre-existing feature (Encarnación, 2004). To the east of the Philippine Fault, the archipelago and its northward continuation into eastern Luzon forms the active volcanic arc at which the West Philippine Basin is subducted along a west-dipping subduction zone (Lee and Lawver, 1995). To the west of the Philippine Fault, dismembered ophiolites show suprasubduction zone affinities in the south, while in the area of Mindoro and Palawan, the ophiolites indicate more-precisely Eurasian suprasubduction zone affinities (Encarnación, 2004). Therefore, the archipelago holds vital clues on the geodynamic evolution of the east Asian margin and western proto-Pacific, and their link to the Tethyan tectonic domain.

The synthesis of Philippine and Luzon ophiolites by Encarnación (2004) suggests that a large portion of the archipelago is underlain by suprasubduction ophiolites emplaced in the latest Jurassic and Early Cretaceous (Fig. 1b), with the Lagonoy Ophiolite yielding the oldest ages derived from a meta-leucodiabase of $156.3 \pm 2.0 \mathrm{Ma}$ amphibole and a meta-gabbro yielding $150.9 \pm 3.3 \mathrm{Ma}{ }^{40} \mathrm{Ar} /{ }^{39} \mathrm{Ar}$ plateau ages (Geary et al., 1988; Geary and Kay, 1989), representing the oldest rocks sampled from the Philippines Archipelago. The Calaguas Ophiolite is slightly younger, but the ${ }^{40} \mathrm{Ar} /{ }^{39} \mathrm{Ar}$ amphibolite intercept age of $99.9 \pm 7.0 \mathrm{Ma}$ represents a minimum age (Geary et al., 1988; Geary and Kay, 1989), with pillow basalts of mid-oceanic ridge and back-arc basin affinities that may have formed within a back arc to the Lagonoy Ophiolite (Encarnación, 2004). Further south, dolerite dykes found on Halmahera record a K-Ar age of $142 \pm 4 \mathrm{Ma}$ on Gag Island, while arc rocks on Obi Island yield $\mathrm{K}-\mathrm{Ar}$ ages of $100 \pm 4 \mathrm{Ma}$, suggesting continuous arc activity in the Early Cretaceous (Hall et al., 1995b), leading Encarnación (2004) to suggest that the archipelago formed through successive ophiolite forming episodes through backarc spreading along pre-existing Late Jurassic crust. Other Late Cretaceous ophiolites, including the Dibut Bay (minimum age of $92.0 \pm 0.5 \mathrm{Ma}{ }^{40} \mathrm{Ar} /{ }^{39} \mathrm{Ar}$ plateau age of an amphibole in an amphibolite; Billedo et al., 1996), Casiguran $(87 \pm 6 \mathrm{Ma}$; K-Ar) and Montalban (Late Cretaceous; biostratigraphy) ophiolites, are correlatable both spatially and 
in age (Billedo et al., 1996; Encarnación, 2004) and may have formed as a result of subduction initiation and back-arc creation along the Calaguas ophiolitic crust (Encarnación, 2004). The Late Cretaceous ages of some Philippine ophiolites mark the onset of volcanism associated with the formation of the Daito Ridge, Minami-Daito Basin and the OkiDaito Ridge with an age range of $\sim 85$ to $49 \mathrm{Ma}$, while rocks in the vicinity of the Amami Plateau yield ages of $\sim 85$ to $60 \mathrm{Ma}$ (Honza and Fujioka, 2004). Geochemical analyses of the rocks indicate that the Daito Ridge is a subductionrelated arc feature, while the Oki-Daito Ridge has closer mid-ocean ridge basalt and seamount affinities (Honza and Fujioka, 2004; Matsuda, 1985; Tokuyama, 1995).

We follow the interpretation of Encarnación (2004) that eastern Luzon, the eastern Philippine Archipelago and at least Obi and Gag islands near Halmahera formed in a suprasubduction setting (i.e., back arc) initiating in the latest Jurassic, consistent with earlier interpretations of pre-Late Cretaceous Philippine Archipelago evolution (Geary et al., 1988; Geary and Kay, 1989; Karig, 1983) in the context of western Pacific tectonic evolution and Philippine Sea plate formation between two opposing subduction zones (Jolivet et al., 1989; Deschamps and Lallemand, 2002; Honza and Fujioka, 2004; Queano et al., 2007). The growth of the Philippine Archipelago through cyclical back-arc opening through slab roll back, often followed by renewed compression and subduction of the back-arc oceanic crust, has resulted in the episodic obduction of ophiolite belts and the accretion of volcanic arcs, representing one of the fundamental mechanisms responsible for the accretionary growth of Southeast Asia (Pubellier and Meresse, 2013). We implement the origin of proto-Philippine Archipelago fragments in the vicinity of the northeastern Gondwana margin, related to the northward transfer of eastern Borneo, Mangkalihat, West Sulawesi and East Java (Figs. 11-12). This "proto"-Philippine Plate forms a back arc resulting from proto-Pacific slab rollback, opening between $\sim 155$ and $115 \mathrm{Ma}$ (Fig. 12b). The collision of the West Sulawesi continental fragments with an intra-oceanic subduction zone at $\sim 115 \mathrm{Ma}$ ceases spreading in the protoPhilippine Plate. By $85 \mathrm{Ma}$, the west-dipping subduction polarity reverses, resulting in the subduction of the protoMolucca and Philippine plates and the transfer of the newly formed fragments of Luzon, eastern Philippine Archipelago and Halmahera onto the Pacific Plate. North-east-dipping subduction along this margin produces the Daito Ridge and Amami Plateau crust, and progresses to back-arc opening to produce the crust older than Anomaly 24 ( $\sim 53$ Ma, Fig. 1b) in the West Philippine Basin (SPSP, Figs. 12-13), largely following the model proposed by Honza and Fujioka (2004) and Queano et al. (2007).

Intricately linked to the Cretaceous plate boundary between the Tethys and the Pacific is the subsequent formation of the West Philippine Basin in the earliest Cenozoic. Seafloor spreading in the central Philippine Basin initiated at Anomaly 24 (Fig. 1b, $\sim 53 \mathrm{Ma}$ ), with a significant change in seafloor spreading direction at Anomaly $20(\sim 44 \mathrm{Ma})$ in the West Philippine Basin with active spreading continuing until $\sim 35 \mathrm{Ma}$ (Hilde and Chao-Shing, 1984). Seafloor spreading ceased in the West Philippine Basin at this time, and westdipping subduction along its eastern margin initiated backarc opening of the Parece Vela and Shikoku basins along the Izu-Bonin-Mariana Arc from $\sim 30 \mathrm{Ma}$ (Sdrolias and Müller, 2006). Whether the Luzon terrane developed within or the periphery of the Philippine Sea plate has been controversial, with Hall (2002) implying an autochthonous origin on the east Asian margin while Deschamps and Lallemand (2002), Queano et al. (2007), Lee and Lawver (1995) and Milsom et al. (2006) prefer an allochthonous origin along a continuous East Philippine Arc, growing on the southern margin of the West Philippine Basin and resulting from northwarddipping Neo-Tethyan subduction. Onset of magmatism on Luzon is synchronous to magmatic episodes on Halmahera in the early Cenozoic (Queano et al., 2007), suggesting that much of Luzon was allochthonous to the east Asian margin. Although not entirely conclusive, paleo-latitudinal estimates suggest north-eastern Luzon was slightly south of the Equator between $\sim 50$ and $30 \mathrm{Ma}$ (Queano et al., 2007), while Mindoro and western portions of Luzon and the western Philippine Arc indicate east Asian affinities and a formation autochthonous to the east Asian margin (Rangin et al., 1985; Yumul Jr. et al., 2003). We largely follow the model of Queano et al. (2007), Deschamps and Lallemand (2002) and Seton et al. (2012) for the evolution of the Philippine Sea plate, with both north-dipping subduction consuming the Australian Plate and southwest-dipping subduction consuming the Pacific Plate, to open the West Philippine Basin between $\sim 55$ and $33 \mathrm{Ma}$. We invoke that a pre-existing transform fault on the eastern margin of the Philippine Sea plate converts to a subduction zone resulting from a change in relative plate motions, triggering the onset of southwest-dipping subduction of Pacific crust at $\sim 55 \mathrm{Ma}$. Northeastern Luzon forms on the Philippines southern intra-oceanic arc, while westernmost portions of Luzon develop on the east Asian margin in the vicinity of Mindoro.

The relative position of the Philippine Sea plate to the Eurasian, Pacific and Australian plates is notoriously difficult to constrain as a result of long-lived Cenozoic subduction along the margins of the Philippine Sea plate (Hall et al., 1995b). Fuller et al. (1983), Haston and Fuller (1991), Ali and Hall (1995) and Hall et al. (1995b) used paleomagnetic data to constrain the latitudinal and rotational motion of the Philippine Sea plate. However, the rotational history derived from scarce paleomagnetic data may indicate the rotation of individual blocks rather than whole-plate rotation, as is exemplified by the conflicting rotation histories from Luzon (Fuller et al., 1991). The study of Haston and Fuller (1991) suggested up to $80^{\circ}$ of clockwise $(\mathrm{CW})$ rotation of the Philippine Sea plate since the Eocene, while the Hall et al. (1995b) model requires a whole-plate $50^{\circ} \mathrm{CW}$ rotation between $\sim 50$ and $40 \mathrm{Ma}$, no rotation between $\sim 40$ and 


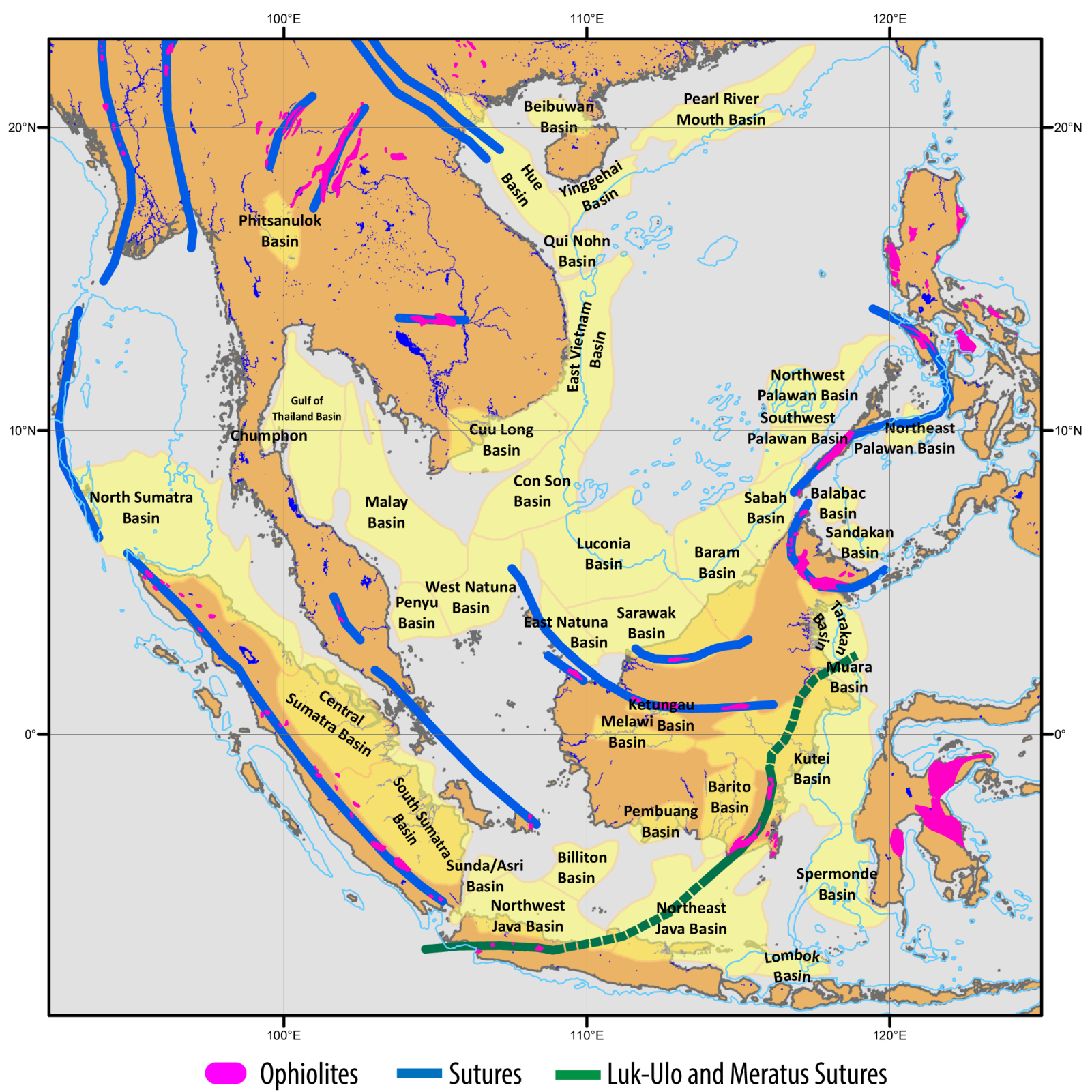

Fig. 13a. Basins (shaded yellow) in Southeast Asia record significant tectonic events, which can be used to help refine timing of extensional and collisional events in plate motion models. The dominant tectonic regime was age-coded to each basin through time following Doust and Sumner (2007). Rivers and lakes (thin dark blue) highlight the present-day drainage patterns. The $500 \mathrm{~m}$ bathymetry contour (thin light blue) is plotted for reference.

$25 \mathrm{Ma}$, followed by $35^{\circ} \mathrm{CW}$ rotation between $\sim 25$ and $5 \mathrm{Ma}$. Additionally, the paleomagnetic data indicate largely Southern Hemisphere low latitudes in the Cenozoic (Hall et al., 1995a; Hall et al., 1995b); however, the data are confined to the southwestern extremity of the Philippine Sea plate in the vicinity of Halmahera. It is questionable whether Halmahera and nearby islands are part of the Philippine Sea plate, and therefore it is uncertain if the data collected in this region represents the rotational history of the entire plate. The synthesis of present-day plate boundaries using seismological evidence interpreted by Bird (2003) indicates an active subduction zone west and east of Halmahera, isolating Halmahera from the Philippine Sea plate. The eastern subduction zone along Halmahera (as the continuation of the Philippine Trench) likely initiated in the late Miocene (Lee and Lawver, 1995) and propagated southward to consume Philippine Sea crust, resulting in a west-dipping slab (PSP, Fig. 10f-g). In addition to the conflicting rotation histories, paleomagnetic data cannot be used to infer the longitudinal position of the 

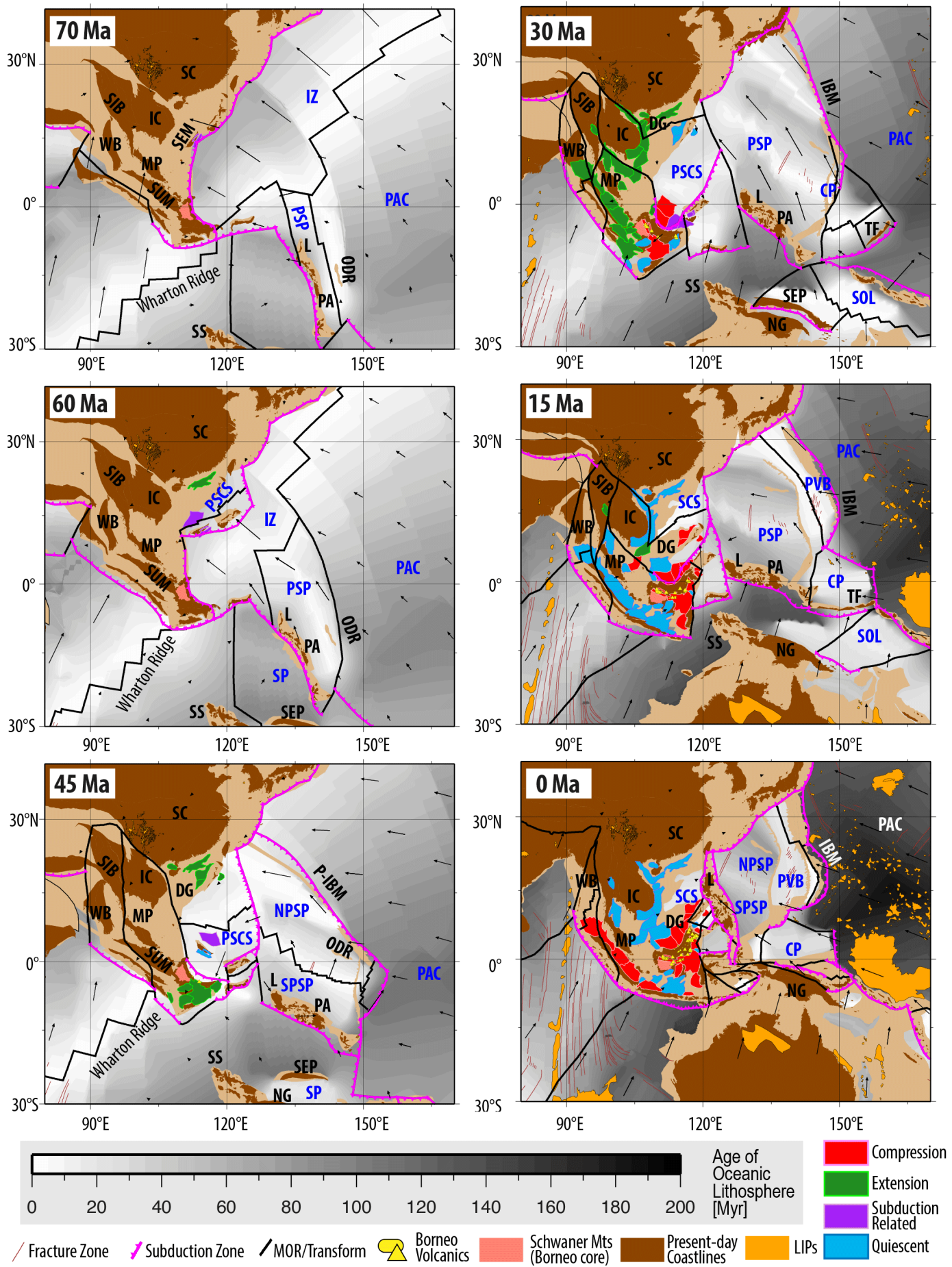

Fig. 13b. Regional reconstructions are plotted with seafloor age, continental extents, reconstructed present-day coastlines, LIPs, plate boundaries, velocities, age-coded basins and Borneo volcanics from Soeria-Atmadja et al. (1999). The proto-Izu-Bonin-Mariana (P-IBM) west-dipping subduction initiates by 55 Ma following a conversion of a transform to a convergent plate boundary to consume Pacific (PAC) crust. The proto-South China Sea (PSCS) opens as a back-arc basin from 65 Ma, with seafloor spreading initiating by $59 \mathrm{Ma}$ that detaches the Semitau (SEM) and South Palawan blocks from mainland South China (SC). These blocks collide in the mid-Eocene with northern Borneo, resulting in the Sarawak Orogeny and cessation of north-west-dipping subduction of Izanagi (IZ) crust in this region. Subduction re-initiates at a south-dipping convergent margin along northern Borneo by $\sim 40 \mathrm{Ma}$ to result in slab pull driving the rifting and opening of the South China Sea (SCS) from 37 Ma, with seafloor spreading initiating by $32 \mathrm{Ma}$ and detaching the Luconia-Dangerous Grounds-North Palawan blocks (DG) from South China. Continued subduction transfers these blocks to northern Borneo and South Palawan, resulting in suturing, ophiolite obduction and the Sabah Orogeny by $\sim 15 \mathrm{Ma}$. Borneo rotates counterclockwise by $\sim 80^{\circ}$ since $50 \mathrm{Ma}$, of which $50^{\circ} \mathrm{CCW}$ motion relative to Sumatra between $\sim 25$ and 10 Ma. Basins were age-coded from Doust and Sumner (2007) and color-coded by their dominant tectonic regime, and indicate extension occurred in the Makassar Straits between $\sim 55$ and $35 \mathrm{Ma}$, while the Java Sea basins largely experience extension between 35 and $25 \mathrm{Ma}$, followed by a period of quiescence and tectonic inversion (compression) from $\sim 15 \mathrm{Ma}$. The convergence of the Australian-Pacific-Sunda plates at present day has resulted in largely compressional regimes parallel to the Java-Sunda and Palawan trenches, along with the basin inversion experienced in the Makassar Straits resulting from the collision of the Sula Spur (SS) with Sundaland. SIB -Sibumasu, IC - Indochina, MP - Malay Peninsula, SS - Sula Spur, SP-Sepik Plate, SEP-Sepik composite terrane, NG-New Guinea, ODR-Oki-Daito Ridge, PVB - Parece Vela Basin. All other label descriptions are found in Fig. 12b. High-resolution animations are included in the Supplement (Mercator projection with $125^{\circ} \mathrm{E}$ standard parallel). 
Philippine Sea plate due to the radially symmetrical magnetic field (see Torsvik et al., 2008b).

We use the paleomagnetic estimates from Hall et al. (1995b) and the seafloor spreading histories within the Philippine Sea plate from Müller et al. (2008) and Sdrolias et al. (2004), and then calibrate the subduction zone locations on the periphery of the Philippine Sea plate with agecoded slab material for the Cenozoic (Fig. 8). We age-code slab material from a P-wave seismic tomographic model (Li et al., 2008), based on an assumption of constant sinking velocities, as a first-order estimate, in the upper and lower mantle, of 3.0 and $1.2 \mathrm{~cm} \mathrm{yr}^{-1}$ vertical sinking, respectively, following Hafkenscheid et al. (2006) and Zahirovic et al. (2012). This method is appropriate because the Philippine Sea plate cannot be linked to the Eurasian, Indo-Australian or Pacific plate circuits since the Eocene as it is almost entirely bound by subduction zones. However, we acknowledge that age-coding of slabs is likely an oversimplification assuming vertical and constant sinking rates, where slab sinking rates are likely variable along-strike due to the oblique convergence vectors in this region (Sdrolias and Müller, 2006). We prefer the stratified mantle sinking scenario, with 3.0 and $1.2 \mathrm{~cm} \mathrm{yr}^{-1}$ sinking in the upper and lower mantle, respectively, compared to a whole-mantle sinking rate of $1.4 \mathrm{~cm} \mathrm{yr}^{-1}$ (Fig. 8). The Java-Sunda trench has been less mobile than the trenches of the Philippine Sea plate, and therefore allows us to calibrate slab material in the seismic tomographic model with the trench locations in our plate motion model. In contrast, the Philippine Sea plate is thought to have rotated by $\sim 50^{\circ}$ between 50 and $40 \mathrm{Ma}$ alone from paleomagnetic estimates (Hall et al., 1995a, b). Although the Java-Sunda trench has moved in response to the IndiaEurasia collision, its motion in the Cenozoic is better constrained through Eurasian plate circuits (Lee and Lawver, 1994, 1995). As a result, it justifies our choice to calibrate our sinking rate estimates to the Java-Sunda trench, and apply it to fine-tuning the rotation of the Philippine Sea plate in the Cenozoic using positive seismic velocity anomalies in the mantle, as an additional constraint to paleomagnetic interpretations. The process of fine-tuning the rotations of the Philippine Sea plate, as a whole, involved superimposing the reconstructions and plate boundaries of Seton et al. (2012) on age-coded depth slices of the high-resolution P-wave model of $\mathrm{Li}$ et al. (2008). The finite Euler rotations were modified interactively in GPlates so that the reconstructed trenches coincide with bands of fast seismic velocity anomalies, interpreted to be slab remnants in the mantle. In doing so, we maintain the relative plate motions within the West Philippine Basin and the back-arc opening related to Izu-BoninMariana rollback, constrained by preserved seafloor spreading histories (Gaina and Müller, 2007; Seton et al., 2012). By fine-tuning the absolute motion of the Philippine Sea plate, we attempted to preserve the convergence with the IndoAustralian Plate, while simultaneously accommodating the opening of the Parece Vela and Shikoku basins from the roll- back of the Pacific slab, resulting in a west-dipping slab interpreted in seismic tomography (PAC, Fig. 10d-g). Our resulting model invokes CW rotation of the Philippine Sea plate between $\sim 45$ and $35 \mathrm{Ma}$, followed by little to no rotation between $\sim 35$ and $25 \mathrm{Ma}, \mathrm{CCW}$ rotation between $\sim 25$ and $15 \mathrm{Ma}$, followed by $\mathrm{CW}$ rotation to present day, which differs from the estimates by Hall et al. (1995b). The CW rotation of the Philippine Sea plate between $\sim 45$ and $35 \mathrm{Ma}$ in our model may be due to more rapid slab rollback of the (proto-)Izu-Bonin-Mariana subduction zone consuming Pacific crust relative to the trench rollback on the southern margin of the Philippine Sea plate (Figs. 12b, 13b and animations in the Supplement). Conversely, the $\mathrm{CCW}$ rotation between $\sim 25$ and $15 \mathrm{Ma}$ may be driven by faster rollback of the southern Philippine Sea plate subduction zone relative to the rollback of the Izu-Bonin-Mariana trench, likely accompanied by more subduction of Philippine crust along the east Asia convergent margin. Testing alternative rotation histories for the Philippine Sea plate and the assumption of constant and vertical sinking rates applied to seismic tomography can be achieved with global numerical models of subduction, where the present-day prediction of slab material can be validated using observations from a suite of seismic tomographic models.

\subsection{The origin of the Caroline Plate}

An independent Caroline Plate was first suggested by Weissel and Anderson (1978), with Bird (2003) identifying the nature of the plate boundaries using more recent data to infer relative plate velocities from seafloor spreading histories and present-day moment tensor solutions. To the west, the Caroline Plate is bound by the Ayu Trough (Fig. 1), which represents a seafloor spreading system between the Philippine Sea and Caroline plates (Bird, 2003; Weissel and Anderson, 1978). The Sorol Trough, largely a transform boundary at present day (Bird, 2003), accommodates the east-west relative motion with the Pacific and incipient east-dipping subduction of the Caroline Plate along the Mussau Trench (Fig. 1). Interpretations of magnetic lineations in the eastern Caroline Basin suggest active seafloor spreading occurred on the Kiilsgaard Trough between Anomalies 13 and $9(\sim 33.5$ and $\sim 27 \mathrm{Ma}$, respectively) based on the model of Weissel and Anderson (1978). Reinterpretation of the magnetic anomalies by Gaina and Müller (2007) identified Anomalies $8 \mathrm{n}$ to $15 \mathrm{r}$ ( 35 to $26 \mathrm{Ma}$, respectively) in the East Caroline Basin, and Anomalies 8r to $16 \mathrm{n}$ (36 to $26 \mathrm{Ma}$, respectively) in the West Caroline Basin, separated by the hotspot-modified Eauripik Ridge (Altis, 1999) that acted as a transform boundary between the eastern and western spreading systems. Although the relative plate motions are well-constrained within the Caroline Plate, its origin and mechanism of opening is less clear. One end-member model invokes the origin of the Caroline Plate from rollback along the eastern portion of the Philippine Sea plate, along the proto-Palau, Yap and 
Mariana trenches (Fig. 1) with a back-arc origin of the Caroline Plate from $\sim 40 \mathrm{Ma}$ (Hall, 2002). An alternative Pacificorigin model assumes that the Sorol Trough was originally a fracture zone (Altis, 1999), with slab-pull-related tensile forces acting on the plate resulting in a tear of the Pacific Plate and initiating seafloor spreading to accommodate Caroline Plate formation. The initial necking that led to rifting has also been suggested to be hotspot-related, to produce the gravitational and topographic anomalies of the Sorol Trough and the Caroline Ridge. The initiation of Caroline Plate subduction in the north-west along the Palau Trench and Yap Trough (Fig. 1), bounding the Philippine Sea plate, and the approach of the Caroline Plate with the leading edge of the Australian plate likely initiated the counterclockwise rotation of the Caroline Plate and the onset of seafloor spreading in the Ayu Trough from $\sim 15 \mathrm{Ma}$ (Gaina and Müller, 2007).

We largely follow the Hall (2002) and Gaina and Müller (2007) models for the Caroline Plate formation on the eastern boundary of the Philippine Sea plate, but acknowledge that the Caroline Plate may have had a Pacific origin as proposed by Altis (1999). In our model, the Mussau Trench acts originally as a transform, and accommodates the rollback and seafloor spreading within the overriding Caroline Plate from $\sim 45 \mathrm{Ma}$, with west-dipping subduction consuming Pacific crust from $\sim 25$ to $4 \mathrm{Ma}$ to accommodate convergence between Pacific and Caroline seafloor (PAC, Fig. 10e). In the last $1 \mathrm{Myr}$, the Mussau Trench reversed subduction polarity to consume Caroline Plate crust at an east-dipping subduction zone (Fig. 1, MUS in Fig. 10e). We model the origin of the intra-oceanic Torricelli-Finisterre Arc on the southern margin of the Caroline Plate, following Hall (2002), that collides progressively with northern New Guinea from $\sim 6 \mathrm{Ma}$. An alternative interpretation, also consistent with the surface geology of the Cyclops Ophiolite ( $\sim 43$ Ma boninites), is provided by Monnier et al. (1999), who advocate southdipping subduction in the Eocene along northern Australia to account for the eventual accretion of arc material onto northern New Guinea. We prefer north-dipping subduction to generate the northward slab pull required to open the Australian Southern Ocean, with the Cyclops Ophiolite generated in a fore arc along the young Caroline Plate.

\subsection{Post-Late Cretaceous accretion and rift histories of the north New Guinea margin}

The New Guinea margin, as the leading edge of the Australian continent, has undergone collisional and extensional episodes related to the complex convergence of Australian, Eurasian and (proto-)Pacific plates. The arc-continent collisions and accreted terranes on northern New Guinea have uplifted margin-parallel mountain chains and obducted ophiolite belts (Baldwin et al., 2012; Abbott et al., 1994) (Fig. 1). Although no seafloor spreading history has been preserved between the core of New Guinea and the accreted terranes, a number of Cretaceous and Eocene sedimentary units record oscillations between a convergent setting to an extensional passive margin, terminated by ophiolite obduction events (Cullen et al., 2012; Baldwin et al., 2012; Pigram et al., 1989). The youngest accretionary event is related to the arc-continent collision of the Finisterre-Torricelli terranes (Figs. 1, 12 and 13) with the New Guinean continental crust, beginning at $\sim 3.7 \mathrm{Ma}$ in the northwest Finisterre Ranges and propagating towards the southeast (Abbott et al., 1994). The Ramu-Markham Fault (Fig. 1) that is the remnant of the north-dipping subduction zone between the accreted arcs and mainland is largely a strike-slip system on land, while its ocean-ward continuation to the east forms the active New Britain Trench along which the (proto-)Solomon Plate is being subducted (Baldwin et al., 2012; Cullen and Pigott, 1989). The Finisterre-Torricelli Arc likely formed at an intraoceanic subduction setting on the southern margin of the Caroline Plate, with the Finisterre volcanics yielding Oligocene to Early Miocene ages (Baldwin et al., 2012). In addition, Cretaceous-age plutons found in the Torricelli Mountains suggest that the arc system may be much older and overprinted by younger subduction-related volcanics (Cullen and Pigott, 1989). The Torricelli intrusive complex yields ages of 75 to 70 Ma based on K-Ar methods, followed by an Eocene episode of formation from between 42 and $18 \mathrm{Ma}$ (Klootwijk et al., 2003). The volcanic data suggest that the Finisterre volcanics are likely related to Caroline Plate origin of the arc, whilst the older Cretaceous-age plutons indicate that parts of the Torricelli Arc are related to an older convergent margin.

South of the Torricelli-Finisterre terranes, the Sepik terrane is the single largest accreted block representing an older collisional system with both continental and intra-oceanic island arc affinities (Klootwijk et al., 2003). Cooling histories derived from $\mathrm{K}-\mathrm{Ar}$ thermochronology indicates that the Sepik terrane accreted to northern New Guinea between 27 and $18 \mathrm{Ma}$, while a later peak at $6 \mathrm{Ma}$ likely represents the arrival of the Torricelli-Finisterre Arc at the margin (Crowhurst et al., 1996). The paleomagnetic model from Klootwijk et al. (2003) suggest that the composite Sepik terrane was at $\sim 20^{\circ} \mathrm{S}$ during the mid-late Eocene, along which Australian oceanic floor was subducting at a north-dipping subduction zone. We model the rifting of Sepik from New Guinea in the Late Cretaceous (from $\sim 80 \mathrm{Ma}$ ), consistent with the Campanian-Maastrichtian (83.6 to $72.1 \mathrm{Ma}$ ) timing proposed by Hill and Hall (2003). The mechanism for this rifting is uncertain, with either slab pull from north-dipping subduction of the proto-Molucca Plate at an Asia-Pacific subduction zone or south-dipping subduction along Sepik resulting in back-arc opening and detachment of continental material. We prefer north-dipping subduction of the protoMolucca Plate (Fig. 12b and PMOL in Fig. 10d-e), consistent with the contemporaneous northward subduction of the Neo-Tethyan oceanic crust.

Our scenario implies that the Mastrichtian (72.1 to $66 \mathrm{Ma}$ ) Emo volcanics (Worthing and Crawford, 1996), and potentially the Late Cretaceous Torricelli intrusive complex, 

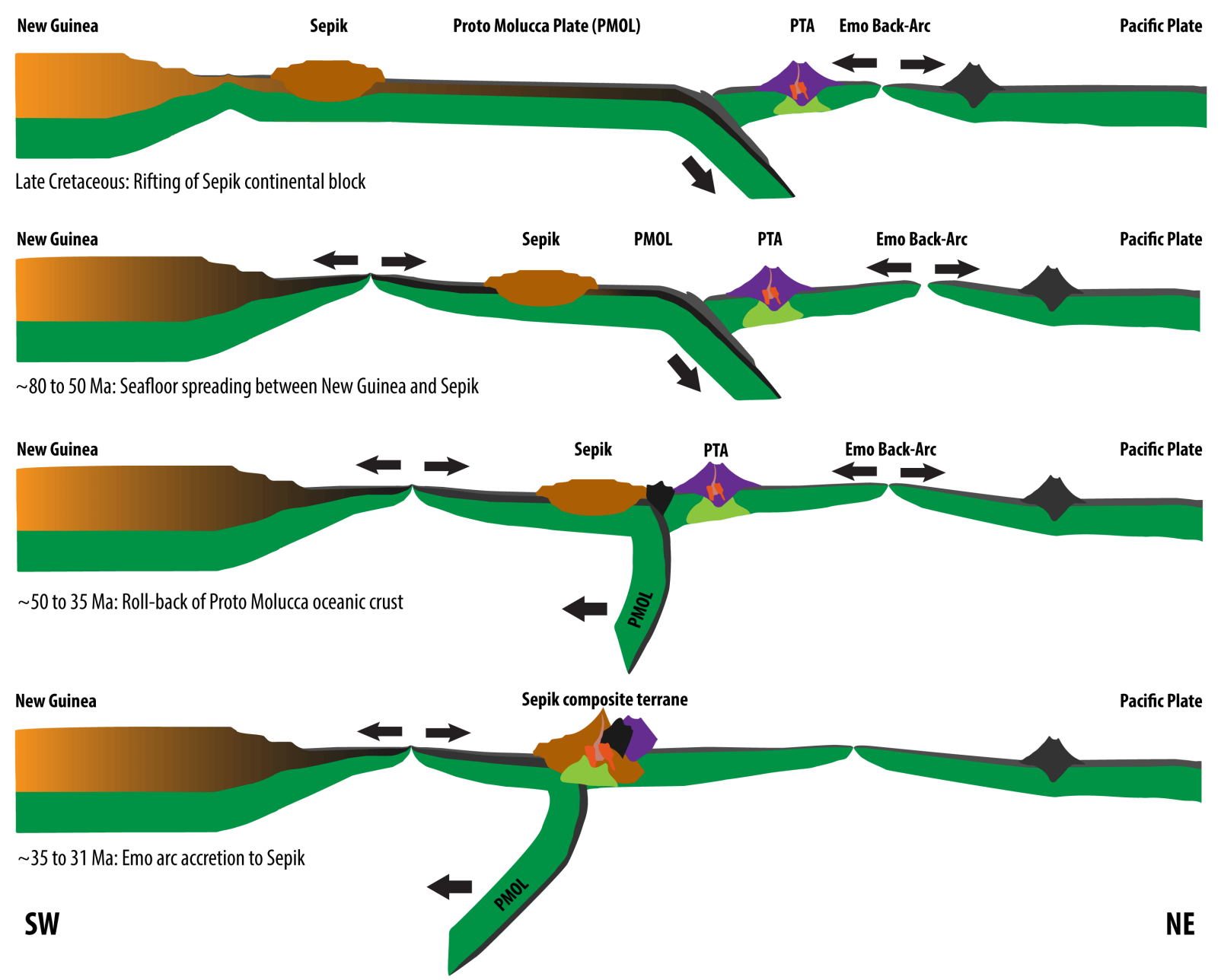

Fig. 14. Schematic cross section of Sepik tectonic evolution depicting a Late Cretaceous rifting scenario of the Sepik continental fragment and eventual collision and accretion of the Emo volcanics that formed in a back-arc setting, likely on the periphery of the Pacific Plate resulting from rollback of the proto-Molucca slab (PMOL). The PMOL slab may have been overridden by the leading edge of New Guinea due to the northward motion of the Australian continent, and the buoyancy of the young Sepik oceanic lithosphere. However, numerical models of subduction will be useful to test the vertical sinking and lateral advection of slab material from this subduction zone. The Emo volcanic arc accretes to Sepik, leading to continued north-dipping subduction of Cretaceous-age seafloor, terminating at $27 \mathrm{Ma}$ when the Sepik composite terrane is accreted onto northern New Guinea. PTA - proto-Torricelli Arc. Cross section largely follows the profile (dashed green) in Fig. 11. Not to scale.

to be emplaced in a Pacific-derived back arc (Fig. 14), southeast of the Philippine Arc, rather than a back arc along Sepik. The northward advance of New Guinea and the southward rollback of proto-Molucca crust results in eventual accretion of the Emo volcanics and associated ophiolites onto the leading edge of New Guinea, which is supported by the northdipping Owen Stanley Fault on the southern margin of the Emo metamorphics and volcanics. Published ${ }^{39} \mathrm{Ar} /{ }^{40} \mathrm{Ar}$ amphibolite ages for the Emo metamorphics of 35 to $31 \mathrm{Ma}$ have been linked to a collision and obduction of the Papuan Ophiolite (Worthing and Crawford, 1996) onto New Guinea. The seafloor separating Sepik from New Guinea is consumed along a north-dipping subduction zone from $\sim 50 \mathrm{Ma}$ (Baldwin et al., 2012; Ryburn, 1980), with collision and suturing to
New Guinea occurring diachronously from $27 \mathrm{Ma}$ in the west and $16 \mathrm{Ma}$ in the east based on cooling histories of exhumed blocks (Crowhurst et al., 1996). The obducted seafloor forms part of the April Ultramafic Belt in New Guinea (Baldwin et al., 2012). However, this north-dipping subduction polarity is also disputed, and may have been south-dipping. We implement north-dipping subduction in order to provide both the northward ridge push and slab pull on the Australian plate during this time to account for an acceleration in AntarcticaAustralia seafloor spreading from $\sim 43 \mathrm{Ma}$ (Williams et al., 2011), and is consistent with arc volcanism on both JavaSunda and Sepik (Fig. 3). By $23 \mathrm{Ma}$ the leading edge of the Australian plate was interacting with the Sundaland margin, with the collision of the Sula Spur with the Sunda trench 
and West Sulawesi (Hall, 2002; Hall, 2012). The intervening seafloor between the Sepik and Finisterre-Torricelli terranes, the westward portion of Solomon Plate (SOL, Fig. 12b), is consumed at a north-dipping subduction zone, with arccontinent collision propagating eastward from 6 to $3 \mathrm{Ma}$ based on another peak in collision-related exhumation (Baldwin et al., 2012; Crowhurst et al., 1996). The Banda Sea develops through slab rollback into the existing Banda Embayment to consume the Jurassic crust from 9 Ma (Hall, 2012; Hinschberger et al., 2005), leading to the present-day configuration of plate boundaries accommodating continued convergence between Australia and Southeast Asia.

\subsection{The evolution of northern Sundaland and the opening of the South China Sea}

The origin of the southwest Borneo core is disputed, with some studies proposing a South China autochthonous origin (Ben-Avraham and Uyeda, 1973), while more recent studies argue for an Early Cretaceous origin of the Borneo core from northern Gondwana (Hall, 2012; Metcalfe, 2011) to dock with Sundaland in the Late Cretaceous along the Billiton Depression (Figs. 2 and 5). However, neither Metcalfe (2011) nor Hall (2012) present any paleomagnetic evidence to support a Southern Hemisphere position of the Borneo core in the Early Cretaceous. Instead, the continuity of the Fukien-Reinan volcanic belt and the Danau Formation along the South China margin (Fig. 6) and inside the Borneo core has been invoked to represent a continuous Andean-style subduction zone along east Asia in the Mesozoic (Charvet et al., 1994; Haile and Bignell, 1971; Honza and Fujioka, 2004; Katili, 1975, 1981; Williams et al., 1988), and the tectonic affinity of Borneo with South China (Ben-Avraham and Uyeda, 1973). Paleomagnetic analysis of Schwaner zone plutonic rocks by Haile et al. (1977) indicates that Borneo was largely fixed to the Malay Peninsula at near-equatorial latitudes as part of Sundaland with a total counterclockwise rotation of $50^{\circ}$ since the mid-Cretaceous. The mostly granitic rocks analyzed had age ranges from the Late Jurassic to the Late Cretaceous, with the Schwaner granitoids largely yielding ages ranging between 154 and $76 \mathrm{Ma}$ (Haile et al., 1977), based on whole-rock K-Ar methods. Similar ages ranging between 112 and $77 \mathrm{Ma}$ have been reported from islands in the vicinity of the Natuna paleosubduction zone (Bignell, 1972; Haile and Bignell, 1971; Haile et al., 1977; Kirk, 1968), indicating continuity of the magmatic arc along Borneo and into the Indochinese continental margin. A Jurassic pole, corrected for structural tilt, from Tiong Cihan sediments on Borneo, within the synthesis of Fuller et al. (1991), has an inclination of $2.4^{\circ}$ and indicates a paleo-latitude of $\sim 1.2 \pm 5.4^{\circ}(\mathrm{N} / \mathrm{S})$ following van Hilten (1962) to suggest a near-equatorial position of the southwest Borneo core rather than high southern latitude position on the Gondwana margin.
The Late Cretaceous is a time of considerable change along the east Asian margin, with the cessation of magmatism and the onset of extension along southeast China by $\sim 90 \mathrm{Ma}(\mathrm{Li}, 2000)$ and likely back-arc rifting of the east Asian margin (Morley, 2012). This event has previously been linked to the intersection of Izanagi-Pacific midoceanic ridge with the east Asian subduction zone (BenAvraham, 1978), leading to a hiatus in subduction due to the buoyancy of young crust on the eastern flank of the midoceanic ridge. However, the model of Seton et al. (2012) prefers the intersection of this ridge with the east Asian trench in the Eocene, between 55 and $50 \mathrm{Ma}$, to account for the plate reorganization in the Pacific and the emplacement of the Okitsu Melange from the arrival of hot buoyant material at the east Asia subduction zone at $\sim 55 \mathrm{Ma}$ (Agar et al., 1989). Therefore, the Late Cretaceous onset of extension along the east Asian margin is likely a result of Izanagi Plate slab rollback (Li et al., 2012) rather than ridge intersection with the margin.

The South China Sea plays an important role in recording changes in the region's tectonics, and is well-studied due to its hydrocarbon potential. A number of NNE-NE trending basins adjacent to the South China margin (Fig. 13a) record at least two major phases of rifting (Fig. 15) - with an early rift phase during the Late Cretaceous-early Eocene followed by another phase from the mid-Eocene to early Oligocene (Ren et al., 2002; Hayes and Nissen, 2005). The earliest phase has been linked to the opening of the protoSouth China Sea in either a back-arc setting on the east Asian margin (Honza and Fujioka, 2004; Li, 2000; Zhou et al., 2008) or slab-pull-induced microcontinent detachment from subduction along northern Borneo (Deschamps and Lallemand, 2002; Doust and Sumner, 2007). The Late Cretaceous east Asian margin records a significant shift from convergent to extensional setting with cessation of volcanism at the continental Andean-style margin by $\sim 60 \mathrm{Ma}$ (Jahn et al., 1976), marking the switch from Andean-style subduction to resemble the modern western Pacific setting dominated by back arcs and intra-oceanic subduction zones ( $\mathrm{Li}$, 2000; Li et al., 2012). Northern and central Mindoro in the Philippine Archipelago record metamorphism that is older than Late Cretaceous based on the ages of units overlying the metamorphic basement (Sarewitz and Karig, 1986; Yumul et al., 2009), and as old as Late Paleozoic based on $\mathrm{Sr}$ compositions found in marble samples (Knittel and Daniels, 1987), to indicate that Mindoro may have older continental basement. The Zambales Ophiolite on westernmost Luzon, comprised of arc and back-arc assemblages, indicates Eocene ages (based on the sediments overlying the ophiolitic basement) and quartz-rich schists that are not found elsewhere on Luzon and include a metamorphosed continental protolith originating from the South China margin that shares affinities with continental rocks from Mindanao, Panay and Palawan (Hawkins and Evans, 1983). The Amnay Ophiolite on Mindoro has a formation age of $59 \mathrm{Ma}$ from $\mathrm{K}-\mathrm{Ar}$ dating 
of hornblende separates (Faure et al., 1989) while the nearby correlatable Sibuyan Ophiolite shows back-arc affinities (Dimalanta et al., 2006; Yumul et al., 2009), suggesting that they likely formed in a Paleocene back arc adjacent to Paleozoic basement, likely on the South China continental margin. The Semitau continental fragment in Borneo, located between the Boyan and Lupar sutures, may be a candidate for a continental fragment originating on the South China continental margin (Metcalfe, 1996) that detached through back-arc rifting with continued rollback transferring it to northern Borneo to open the proto-South China Sea in the latest Cretaceous, analogous to the mechanism proposed for the ApenninesTyrrhenian system in the Mediterranean (Doglioni, 1991; Rehault et al., 1987). For the successor of the proto-South China Sea, the models of Briais et al. (1993), Tongkul (1994) and Doust and Sumner (2007) imply extrusion tectonics in Southeast Asia and south-dipping subduction along northern Borneo by the Eocene triggers rifting and renewed microcontinent detachment from the South China margin to open the South China Sea. Alternatively, the model of Schlüter et al. (1996) invokes back-arc rifting and extension of the Dangerous Grounds, Reed Bank, Palawan and west Mindoro continental blocks that rifted from mainland China in the Late Cretaceous-Eocene. Although we find the seismic line data and timings of major regional events from Schlüter et al. (1996) helpful, we fundamentally disagree with the mechanism that is proposed for South China Sea opening as a back arc, and we prefer that the South China Sea opens initially as a pull-apart basin resulting from the combination of extrusion tectonics acting on the South China and Indochina blocks, and the south-dipping subduction of the proto-South China Sea along northern Borneo (Briais et al., 1993). A back-arc opening of the South China Sea would require a volcanic arc on Dangerous Grounds-Reed Bank, for which no evidence exists.

We implement the opening of the proto-South China Sea from $\sim 65 \mathrm{Ma}$ (Figs. 12b and 13b), with back-arc rifting along South China to separate the Semitau block from the mainland and account for the incipient opening of the Beibu Gulf (Beibuwan Basin, Fig. 13b) in the Maastrichtian ( 72.1 to $66 \mathrm{Ma}$ ) (Clift and Lin, 2001). The back-arc scenario is consistent with the onset of an extensional east Asian margin in the Late Cretaceous ( $\mathrm{Li}, 2000)$, the back-arc affinity of ophiolites emplaced at $\sim 59 \mathrm{Ma}$ found on Mindoro (Yumul et al., 2009) and the cessation of Andean-style magmatism on the east Asian margin (Jahn et al., 1076). The onset of tectonic subsidence of the east Asian basins from $\sim 65 \mathrm{Ma}$ (Lin et al., 2003; Yang et al., 2004) is used as a proxy for the onset of back-arc rifting (Fig. 15). We propose that Mindoro and Palawan were rifted from mainland South China in the latest Cretaceous, with seafloor spreading being established in the back arc by $59 \mathrm{Ma}$ to emplace the Sibuyan and Amnay ophiolites, which were later obducted and accreted to Luzon (Fig. 1b). We model the detachment of the Semitau block from the South China mar-

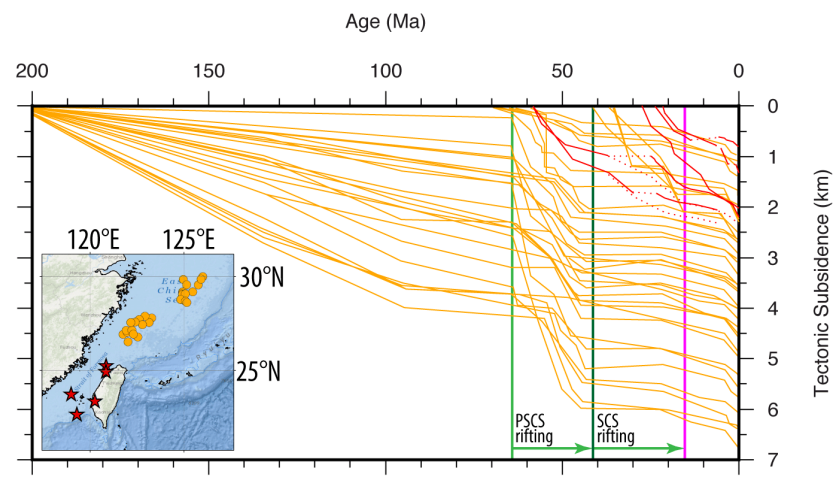

Fig. 15. Tectonic subsidence records from basins adjacent to Taiwan and east China indicate an acceleration of tectonic subsidence from $\sim 65$ Ma that we interpret to be the opening of the proto-South China Sea (PSCS) as a back-arc basin, followed by another episode of subsidence in the mid-Eocene $(\sim 42 \mathrm{Ma})$ resulting from South China Sea (SCS) rifting. Figure modified from Lin et al. (2003) (red) and Yang et al. (2004) (orange).

gin at this time through back-arc rifting, based on the biological affinities between Triassic and Jurassic fossil assemblages on Semitau with South China (Fig. 6). This scenario is consistent with the interpretation of Metcalfe (1999) that the Semitau block shows Cathaysian biological affinities and detached from South China or Indochina in the Cretaceous or Cenozoic. Thus the Boyan Suture on Borneo is likely Eocene in age, related to the Sarawak Orogeny and the accretion of Semitau, while the Lupar Line results from southdipping subduction and closure of the proto-South China Sea accompanied by the northward-younging Rajang accretionary complex on Sarawak (Hutchison, 1996). The collision and incipient subduction of Dangerous Grounds-Reed Bank microcontinents and suturing to Borneo occurred at $\sim 16 \mathrm{Ma}$ to close the proto-South China Sea and terminate seafloor spreading in the South China Sea (Briais et al., 1993), based on unconformities resulting from collisional orogenesis and regional deformation (Hutchison, 2004). We interpret that a slab at depths shallower than $\sim 1000 \mathrm{~km}$ beneath the South China Sea results from south-dipping subduction of the proto-South China Sea (PSCS, Fig. 10e-g). Our scenario requires that the Dangerous Grounds, and associated Reed Bank and northern Palawan, continental blocks collide with Borneo in the Miocene rather than the Cretaceous age ("Luconia") proposed by Hall (2012). A younger age for this event is supported by seismic studies of these continental fragments (Schlüter et al., 1996), derived from South China during the opening of the South China Sea, and previously proposed kinematic models of the region (Clift et al., 2008; Sarewitz and Karig, 1986; Soeria-Atmadja et al., 1999; Tongkul, 1994).

Sundaland played an important role in the extrusion tectonics of SE Asia resulting from the northward impingement of Eurasia by India (Tapponnier et al., 1982). The stability 
of Sundaland during post-collisional times has been investigated using paleomagnetic evidence suggesting distributed block rotations (Hall et al., 2008; Fuller et al., 1999) along a complex network of strike-slip and oblique faults in the region. Much of the extrusion was accommodated along large shear zones and strike-slip zones including the Red River fault (Hall, 2002; Lee and Lawver, 1995; Leloup et al., 1995), bounding Indochina to the north, and to the southwest along the Sagaing, Three Pagodas, Ranong and associated fault zones that partition the lateral extrusion of Indochina (Morley, 2007; Fyhn et al., 2010b). The dominant NW-SE trending Red River-Ailao Shan shear zone, as the boundary between Indochina and South China, has accommodated anywhere between $200 \mathrm{~km}$ (Hall, 2002) and in excess of $500 \mathrm{~km}$ (Lee and Lawver, 1995; Tapponnier et al., 1990; Tapponnier et al., 1982) of left-lateral strike slip motion with an onset of extrusion tectonics as early as $35 \mathrm{Ma}$ (Leloup et al., 2001; Leloup et al., 2007). The motion along the shear zone reversed during the latest Early Miocene (Morley, 2007), with a smaller dextral offset of $\sim 25 \mathrm{~km}$ since $19 \mathrm{Ma}$ (Replumaz et al., 2001). Much of the extrusion of Indochina was partitioned and absorbed along smaller NE-SW trending strike slip faults in western Indochina, in particular in Myanmar, Thailand and Laos (Hall, 2002). The magnitude of motion along these faults have been estimated from river offsets, deformed geological units (striations) and other morphological markers of slip, ranging from $10 \mathrm{~km}$ of motion along the Mae Chan Fault to $50 \mathrm{~km}$ along the Nanting Fault in the Cenozoic (Lacassin et al., 1998; Morley, 2007). Internal deformation of Indochina played an important role along with the wholesale lithospheric-scale expulsion of the Indochina block in absorbing the forces propagated from the India-Eurasia collision zone (Hall, 2002; Hall et al., 2008; Leloup et al., 2001; Tapponnier et al., 1982). Another far-field effect of the collision and the rollback of the Indian subducting slab is the rifting in the Gulf of Thailand (Fig. 13), accommodated largely along the Ranong, Three Pagodas and Khlong Marui fault zones that tectonically isolated the Malay Peninsula from mainland Indochina (Watkinson et al., 2008). The eastward extrusion of Indochina (Leloup et al., 2001; Leloup et al., 2007; Tapponnier et al., 1990) has been linked to the opening of the South China Sea from $32 \mathrm{Ma}$ at the expense of the proto-South China Sea (Briais et al., 1993). The opening of South China Sea was complex, and included a number of abandoned incipient rifts from $\sim 37 \mathrm{Ma}$, initiation of seafloor spreading by $32 \mathrm{Ma}$ and a sequence of southward ridge jumps (Fig. 13b). Coinciding with the end of sinistral motion along the Red River fault at $~ 17$ Ma (Leloup et al., 1995), spreading in the South China Sea ceased (Briais et al., 1993), likely due to the docking of the Dangerous Grounds-Reed Bank continental fragment onto northern Sundaland (Hutchison, 2004; Hutchison et al., 2000). Recent work by Cullen et al. (2012) indicates a strong counterclockwise rotation of Borneo between 30 and $10 \mathrm{Ma}$, and they acknowledge that an earlier counterclockwise rotation was likely overprinted by a $\sim 35$ Ma remagnetization event. The relative motion between Borneo and stable Eurasia is accommodated by the subduction of the proto-South China Sea, meaning that the $\mathrm{CW}$ rotation of Indochina resulting from extrusion tectonics is compatible with the large $\mathrm{CCW}$ rotation of Borneo resulting from oroclinal bending. The oroclinal bending accounts for up to $\sim 78^{\circ}$ of CCW rotation of Borneo relative to Sumatra (Table 4$)$, with a stable pole of rotation $\left(\sim 0^{\circ} \mathrm{N}, \sim 106^{\circ} \mathrm{E}\right)$ near western Borneo (see Table B1 in Supplement B). In addition, the restored shape of the Java-Sunda continental arc is consistent with the geometry of the NW-SE trending age-coded positive seismic velocity anomalies in the mantle (see Sect. 2.4). Reversing oroclinal bending also restores the largely N-S strike of the Natuna and Anambas Cretaceous volcanics arcs that are continuous from the east Asian margin and into the southwest Borneo core. An interesting by-product of the process allows Belitung (Billiton) Island to be restored to a position adjacent to Bangka Island (Fig. 7) and implies the continuity of the Tin Belt eastward (Katili, 1975), and the Mid- to Late Triassic granitic arc (Hutchison, 2010). This restored position of the Bangka-Belitung islands assumes that Belitung moves with a half-stage rotation between Borneo and Sumatra, simulating the stretching of the continental crust of Sunda Shelf during oroclinal bending.

We implement the $\sim 500 \mathrm{~km}$ total displacement along the Red River shear zone following Lee and Lawver (1995), partitioned along splayed faults and internal block deformation south of the Red River fault (Hall, 2002). The Makassar Strait opens from $\sim 50$ to $17 \mathrm{Ma}$ (Lee and Lawver, 1994) (Fig. 13b), and Borneo begins to rotate counterclockwise relative to Sundaland from $\sim 50$ to $10 \mathrm{Ma}$ due to oroclinal bending (Hutchison, 2010). Our preferred model invokes collision of the Semitau continental fragment to northern Borneo in the mid-Eocene to induce the $\sim 37 \mathrm{Ma}$ Sarawak Orogeny (Hutchison, 2010) and a potential metamorphic-induced remagnetization event on Borneo at $\sim 35 \mathrm{Ma}$ (Cullen et al., 2012). Northern Palawan accretes to South Palawan, leading to an ophiolite obduction episode and final closure of the proto-South China Sea with the arrival of the Dangerous Grounds and Reed Bank continental blocks by $17 \mathrm{Ma}$ (Hutchison, 1996; Hutchison et al., 2000). These continental fragments choke the subduction zone, resulting in cessation of seafloor spreading in the South China Sea, the obduction of ophiolites on Palawan and Mindoro and the onset of the Sabah Orogeny in Borneo by $15 \mathrm{Ma}$ (Fig. 3).

The basins on Sundaland record the changes in the dominant tectonic regime acting on the region through time, manifesting as faulting and changes in sedimentation character, as synthesized by Doust and Sumner (2007). We use the Doust and Sumner (2007) synthesis to assign the tectonic regime each basin experienced in Southeast Asia during the Cenozoic, and create time-dependent maps that highlight the changing extensional, quiescent and compressional regimes. Along with the changing tectonic regimes in regional basins, volcanics on Borneo from Soeria-Atmadja et al. (1999) were 
Table 4. Finite Euler rotations interpolated in $5 \mathrm{Myr}$ intervals for Borneo relative to Sumatra derived from our oroclinal bending model for Sundaland.

\begin{tabular}{llll}
\hline Age (Ma) & Lat & Long & Angle \\
\hline 0.0 & 0.00 & 0.00 & 0.00 \\
10.0 & 0.00 & 0.00 & 0.00 \\
15.0 & -0.48 & 106.86 & -16.67 \\
20.0 & -0.61 & 106.72 & -33.35 \\
25.0 & -0.73 & 106.57 & -50.02 \\
30.0 & -0.78 & 106.52 & -55.58 \\
35.0 & -0.82 & 106.47 & -61.13 \\
40.0 & -0.86 & 106.42 & -66.69 \\
45.0 & -0.91 & 106.37 & -72.24 \\
50.0 & -0.95 & 106.32 & -77.79 \\
\hline
\end{tabular}

used to infer the subduction polarity and arc evolution on Borneo. Our model suggests that the Sarawak, Ketungau and Melawi basins were in the vicinity of the Semitau block on the South China margin (Fig. 13 and animation in the Supplement), with depositional styles indicative of an arc or backarc setting (Doust and Sumner, 2007) resulting from the subduction of Izanagi oceanic crust from $\sim 65 \mathrm{Ma}$. The Pearl River mouth basin experienced extension from $\sim 63 \mathrm{Ma}$, while extension in the Beibuwan Basin (Beibu Gulf) and the proto-southwest Palawan basins initiated by 59 Ma related to the opening of the proto-South China Sea. Compression dominated the Ketungau and Melawi basins between $\sim 58$ and $50 \mathrm{Ma}$, followed by a quiescent period in a fore-arc setting until $39 \mathrm{Ma}$. Compression from $\sim 39 \mathrm{Ma}$ in the Melawi Basin is interpreted as the onset of collision of the Semitau block, and the initiation of south-dipping subduction of proto-South China Sea crust. This is consistent with contemporaneous widespread volcanism along northern Borneo. More basins experienced extension on the South China margin from $\sim 45 \mathrm{Ma}$ associated with the incipient rifting of the South China Sea leading to progressive detachment of the Dangerous Grounds-Reed Bank continental block. Extension also propagates to basins associated with the Red River fault from $\sim 32 \mathrm{Ma}$, including the Hue, Qui Nohn and East Vietnam basins, coinciding with the onset of seafloor spreading in the South China Sea at the expense of its predecessor, resulting in compressional regimes in the Luconia, Sarawak, Baram, Sabah, Ketungau and Melawi basins. Widespread extension along the Java-Sunda and Sumatra back arc and the Gulf of Thailand basins is well established by $\sim 34 \mathrm{Ma}$, suggesting a period of slab rollback of Indian Ocean crust. Most of these basins experience quiescence by $\sim 22 \mathrm{Ma}$, followed by a period of basin inversion from $\sim 13 \mathrm{Ma}$. Basins north and west of the Makassar Straits undergo compression from $\sim 18 \mathrm{Ma}$, indicating the arrival of the Sula Spur and initial contact with the northern Australian continental blocks. These compressional regimes continue to present day due to the continued convergence and collision of the Australian continental margin with Asian active margins.

\section{Discussion}

\subsection{Comparison to other published models}

There has been a renewed effort to produce more detailed post-Cretaceous tectonic reconstructions of Southeast Asia, including those of Metcalfe (2011), Hall (2012) and Morley (2012). Our model draws upon such work and many others, cited within. Although there is general agreement that continental fragments detached from northern Gondwana in the latest Jurassic-Early Cretaceous, the pre-rift configuration and destination onto the southern Asian margin varies across the models. We have chosen an approach to invoke the simplest geodynamic scenario required to transfer these blocks onto the Asian active margin. Hall (2012) and Metcalfe (2011) argue southwest Borneo (SWB) core was a Cretaceous Gondwana-derived allochthon. We treat southwest Borneo as the core of the block that developed on Paleozoic metasediments as an eastward continuation of east Sumatra and Malaya, with the Schwaner Mountains I-type plutons developing from generally westward-dipping subduction of Izanagi oceanic crust in the Cretaceous (Hutchison, 1996; Parkinson et al., 1998). We propose that southeast Borneo (east of the Meratus Mountains), East Java and West Sulawesi blocks formed a continental sliver that detached in the latest Jurassic-Early Cretaceous from northern Gondwana (Veevers, 1991; Veevers et al., 1991; Audley-Charles et al., 1988). The interpreted continuity of the east Asian magmatic arc into the southwest Borneo core from Late Jurassic times would indicate a Cathaysian position, proximal to Indochina and the Malay Peninsula (see Sect. 3.7), rather than an origin from Gondwana in the Late Jurassic or Early Cretaceous. In order to account for the mechanism to also close the Woyla back arc along West Burma and Sumatra in the Late Cretaceous, we suggest the possible collision of Gondwanaderived microcontinents sourced from the Argo segment on the NW Australian shelf.

Hall (2012) and Metcalfe (2011) invoke the Billiton Depression on the Sunda Shelf as a paleo-transform boundary and suture along which southwest Borneo docked with Sundaland in the Cretaceous. The paleo-transform nature of the Billiton Depression was first proposed by Ben-Avraham (1978). No literature exists to demonstrate that the Billiton Depression is a suture zone, and all existing work supports that the feature likely results from rifting during the Oligocene and Miocene, related to the coeval rifting in the nearby East Natuna Basin ( 35 to $17 \mathrm{Ma}$, Doust and Sumner, 2007). No evidence of flower structures representing the Billiton Depression as a transform boundary in seismic studies have been published, and we suggest that the mid-Cretaceous suture on Sundaland instead passes through 
Luk-Ulo on Java and the Meratus Mountains on Borneo, following Smyth et al. (2007) and Parkinson et al. (1998) (Fig. 2). However, it is important to note that we agree that the Borneo core is likely Gondwana-derived, but we believe it rifted from Gondwana much earlier (i.e., Triassic times) rather than the latest Jurassic-earliest Cretaceous rifting event (see Sect. 3.7). In the region of the Billiton Depression, we prefer the interpretations that the curved lineaments in the Sunda Shelf and Java Sea support the oroclinal bending model proposed by Hutchison (2010), and suggests that the western core of Borneo was an eastward extension of the Cretaceous Natuna subduction zone. The Cretaceous age subduction-related volcanic chain is presently found in an east-west orientation within the Borneo core. However, when taking into account a counterclockwise rotation (CCW) that exceeds $50^{\circ}$ since the Cretaceous (Hartono, 1985), then the volcanic chain would better correspond to a generally north-south striking subduction zone, with westwarddipping proto-Pacific slabs along eastern mainland Asia. The paleomagnetic-derived rotations of Borneo from the study of Fuller et al. (1999) are consistent with such an orientation of Borneo, suggesting up to $90^{\circ} \mathrm{CCW}$ rotation since $\sim 80 \mathrm{Ma}$, of which up to $50^{\circ} \mathrm{CCW}$ rotation occurred since $\sim 25 \mathrm{Ma}$. The lithospheric structure observed in potential field data (Fig. 4) also supports the notion of a pole of rotation very close to western Borneo (Table 4), resulting in curved structures and oroclinal bending in the Java Sea and the Sunda platform (Hutchison, 2010). As little data exists to constrain the timing of Java Sea rifting, we assume that it was contemporaneous to Makassar Strait opening between 50 and $17 \mathrm{Ma}$ (Lee and Lawver, 1994), consistent with the age of syn-rift sediments (Doust and Sumner, 2007). The lack of continuous transform faults bounding Borneo to accommodate relative rotation to Sundaland require some other mechanism to account for independent rotation of Borneo. We postulate that the oroclinal bending of Sundaland may be related to the changing stress regimes along the Java-Sunda trench to the south and the proto-South China Sea subduction to the north, and the coupling between the subducting and overriding plates in periods of slab rollback.

The paleobiological data from northwest Borneo, north of the Schwaner Mountains and the Borneo core, suggest tectonic affinity with the South China block in the Triassic and Jurassic (Fig. 6). The generalized volcano-stratigraphic column for West Borneo by Williams et al. (1988) indicates that the granitoid and dacite intrusions in northwest Borneo are distinct from the semi-contemporaneous andesitic volcanics and fluvial and marginal marine sediments in the Schwaner Mountains in the latest Cretaceous. The lack of similar stratigraphic units between northwest Borneo (Kalimantan) and the nearby Schwaner Mountains led the authors to conclude that the regions were tectonically distinct. We suggest that the granitoid and dacite intrusives in northwest Borneo may be related to the Semitau volcanic arc, which welded to northern Borneo in the Eocene. The model proposed by Hall
(2012) suggests that northwest Borneo and southwest Borneo core are derived from the collision of a Pacific-derived Dangerous Grounds block, the "Banda block" and "Argoland" by the mid-Cretaceous. This leads to an eastward jump in the location of subduction and a subduction polarity reversal, to initiate intra-oceanic subduction in the proto-Pacific. However, Dangerous Grounds is typically not assumed to be a continuation of the Luconia-Balingian continental fragment that likely docked to northern Borneo sometime in the Eocene (Fyhn et al., 2010a; Hutchison, 1996). We interpret that the Luconia-Balingian continental fragment is part of the Semitau block docking to Borneo in the Eocene, and that the Dangerous Grounds-Reed Bank continental fragment was a separate block that collided to northern Borneo much later, likely in the Miocene (Hutchison, 1996; Hutchison et al., 2000; Lee and Lawver, 1994). In addition, a scenario with an eastward jump in subduction is incompatible with continuous westward directed subduction of the Izanagi Plate in the Cretaceous along eastern mainland Asia (Seton et al., 2012). The detrital zircon provenance and geochemical study by Li et al. (2012) suggests that during this time the east Asian margin was likely dominated by Andeanstyle subduction from $\sim 190$ to $90 \mathrm{Ma}$, followed by slab rollback and associated continental extension from $\sim 65 \mathrm{Ma}$ to produce a margin analogous to the present-day western $\mathrm{Pa}$ cific. We prefer an Izanagi slab rollback induced rifting of east Asian continental crust from $\sim 65 \mathrm{Ma}$, contemporaneous with the onset of basin formation and tectonic subsidence of the South China margin (Lin et al., 2003; Yang et al., 2004) (Fig. 15), and the progression to seafloor spreading in a backarc, documented by the inception of suprasubduction zone ophiolitic oceanic crust on the Mindoro block.

\subsection{Controversies in tectonic affinities and onset of rifting from northern Gondwana in the latest Jurassic}

Most, if not all, of the seafloor documenting the transfer of the Java, east Borneo and West Sulawesi blocks to Sundaland has now been subducted as a result of the long-term northward subduction of oceanic crust north of Australian. We speculate that remnants of the crust representing this seafloor spreading system is presently the Molucca Sea plate (Figs. 1 and 2), as suggested by Wu et al. (2012), who unfolded slabs from positive seismic velocity anomaly contours to determine their paleo-surface extent, similar to the study by Richards et al. (2007), who unfolded the Indo-Australian slab and linked it to the tectonic evolution of the region. In the absence of preserved seafloor, we rely on geological evidence for rifting events from the Gondwana margin and the subsequent collisional event on the Asian margin, assuming generally northward transfer of Tethyan terranes. A critical ambiguity exists in such scenarios, as the pre-rift position of terranes is inherently uncertain due to the lack of preserved conjugate margins (Seton et al., 2012), coupled with uncertain 
sedimentary correlations and biogeographic affinities (Fortey and Cocks, 1998). Paleo-latitude estimates from paleomagnetic data can have errors of $\pm 10^{\circ}$ (e.g., paleo-latitude of Lhasa prior to collision with Greater India, see Zahirovic et al., 2012) and provide no constraints of paleo-longitudes (Torsvik et al., 2008b). Recent work using hafnium (Hf) isotope affinities by Zhu et al. (2011) indicates that the Lhasa terrane (South Tibet) shows strong affinities to coeval detrital zircons from northwest Australia, rather than Greater India, highlighting a robust and meaningful technique to help determine tectonic affinities. However, there are no such studies that can be used to link the pre-rift positions of East Java, east Borneo, Mangkalihat and West Sulawesi to the northwest (NW) Australian shelf (i.e., Argo Abyssal Plain), the New Guinea margin or elsewhere in the Phanerozoic.

The Archean to pre-Cambrian zircon study by Smyth et al. (2007) indicates similarities in relative probability peaks between data from East Java and sediments from the Perth Basin. A more robust conclusion of tectonic affinity would require the additional comparison of inherited zircons from New Guinea and other potential source regions. Hall (2012) and Metcalfe (2011) argue that the alluvial diamonds found on Borneo, indicating an Archean age, can be used to link the southwest Borneo core to the Argo Abyssal Plain on the northwest Australian shelf in the Jurassic. Alluvial diamonds on Kalimantan (Borneo) have an Archean age ( $3.1 \mathrm{Ga}$ ) and are derived from sub-lithospheric continental mantle similar to that of African and Yakutian cratons (Smith et al., 2009). Using nitrogen-defect aggregation characteristics, Bergman et al. (1988) suggest a potential source for Borneo alluvial diamonds to be the Fitzroy Basin in Australia, Coc Pia in Vietnam, Chelima in India or another local unidentified source due to the lack of nearby lamproites. Taylor et al. (1990) and Smith et al. (2009) acknowledge that diamonds from Borneo may have formed in similar thermal conditions as diamonds from Ellendale (western WA) and Copeton (northeast NSW) in Australia. In addition, Smith et al. (2009) note that the morphology and "primary etch features of the Kalimantan diamonds are quite different from any lamproite, kimberlite or alluvial diamonds known from the Kimberley Region of Western Australia". Housh and McMahon (2000) identified a continental mantle reservoir source for rocks on New Guinea that has similarities with the reservoirs responsible for the kimberlite and lamproite emplacements in Western Australia, with a likely Proterozoic or Archean age, indicating that the diamonds on Borneo may have formed adjacent to central and Western New Guinea. As a result, purely relying on alluvial diamonds to place Borneo adjacent to the Argo Abyssal Plain at pre-rift times is inadequate. An Archean age for these diamonds does not help identify the age of rifting from Gondwana, and can only provide a maximum age, while the geographic affinities may link Borneo diamonds to anywhere from Sundaland (Vietnam), India, Western Australia (Ellendale), eastern Australia (Copeton), Africa, Siberia (Yakutian craton), New Guinea or another location. We argue that the southwest Borneo core was already on the Asian margin by the latest Jurassic and likely did not originate adjacent to the NW Australian shelf due to the contrasting diamond provenances with those in the Kimberley Region. However, it likely originated elsewhere on the Gondwana margin and formed the easternmost portion of the Cimmerian terrane that rifted in the early Permian (Metcalfe, 2011). West Sulawesi, East Java, Mangkalihat and easternmost Borneo likely originated from the northern Gondwana margin in the latest Jurassic. Although we place these blocks on the New Guinea margin (Figs. 11-12), we acknowledge that they potentially originated from the Argo Abyssal Plain and the NW Australian shelf as proposed by Hall (2012) to become candidates for the elusive Argoland terrane. We present two end-member kinematic scenarios of the pre-rift position of these blocks on northern Gondwana (Fig. 11) that are consistent with geological constraints (such evidence of seafloor spreading, shallow marine sedimentation and generation of ophiolites) and the Meso-Tethyan models of Gibbons et al. (2012) and Gibbons et al. (2013). However, insufficient constraints currently exist to tie West Sulawesi, East Java and easternmost Borneo to a specific location on the north Gondwana margin. Future work using statistical methods to analyze detrital zircon peaks, such as the study of Burrett et al. (2014), can be applied in order to determine whether Greater India, the NW Australian shelf, New Guinea or another location may better represent the pre-rift position of these continental fragments. The N-MORB geochemical signature, with indications of suprasubduction zone (SSZ) affinity, of the Late Jurassic ophiolites in the central ophiolite belt in New Guinea (Monnier et al., 2000) suggest that our proposed alternative scenario (Fig. 11b) would better explain the Late Jurassic rifting history on the New Guinea margin. However, as acknowledged by Monnier et al. (2000), the $157 \pm 16 \mathrm{Ma} \mathrm{K}-\mathrm{Ar}$ ages are likely to be minimum ages, and may represent back-arc activity (i.e., our Junction Plate) that precedes our model time. Future work would involve testing the geodynamic implications from our proposed endmember scenarios (Fig. 11) using numerical models of subduction and comparing present-day predictions to seismic tomography models of the mantle. When considering plate kinematics, an origin of East Java and associated blocks from the Argo Abyssal Plain (Fig. 11b) would require an Euler rotation close to the Bird's Head in New Guinea to account for the large clockwise rotation required to transfer these fragments onto Sundaland. This in itself is not a problem, but it may require very large plate velocities of the Meso-Tethys north of India and close to Africa, as this portion of the plate would be close to the Euler equator. To address this, an additional mid-oceanic ridge system, with generally eastwest seafloor spreading may be required north of India to accommodate such motion with plausible plate velocities. It was beyond the scope of this study to explore alternative reconstructions of central Meso-Tethyan oceanic crust, and we consider it opportunity for future work. In addition, the al- 
ternative model we have outlined above, including an additional, hypothetical mid-ocean ridge north of India, would be undesirable if we consider these solutions in the context of Ockham's Razor, i.e., we need to use simple models until simplicity can be traded for greater explanatory power, and the explanatory power of the model that we have now is quite good, and is in agreement with most observations considering uncertainties in ages as outlined above.

Mafic rocks as old as $158 \mathrm{Ma}$ on Sulawesi (Polvé et al., 1997) may be inconsistent with the initiation of seafloor spreading in the Argo Abyssal Plain of M24 anomaly identification of Robb et al. (2005) ( 153 Ma using Gradstein et al., 1994 or $\sim 155$ Ma using Gradstein et al., 2012) or M26 identified by Gibbons et al. (2012) ( 156 Ma using Gradstein et al. (1994) or $\sim 157$ using Gradstein et al., 2012). However, the oldest seafloor in the Argo Abyssal Plain from ODP (Ocean Drilling Program) Leg 123, Site 765, yields a $\mathrm{K}-\mathrm{Ar}$ age of $155 \pm 3.4 \mathrm{Ma}$ (Gradstein and Ludden, 1992), suggesting that the mafics on West Sulawesi may in fact represent the earliest seafloor in the Argo Abyssal Plain. The bulk-rock K-Ar age of a basaltic dyke $(\sim 158 \mathrm{Ma})$ derived from West Sulawesi by Polvé et al. (1997) has been used in this study to infer the onset of seafloor spreading and separation of West Sulawesi and associated blocks from Gondwana in the latest Jurassic. However, this assumes that the basaltic dyke and associated microgabbro are associated with the initial seafloor spreading, especially since the pillow basalts found on West Sulawesi indicate an Eocene age and younger (Polvé et al., 1997). Polvé et al. (1997) acknowledge that their samples seem to contain two populations of ages, where the latest Jurassic and Early Cretaceous ages consistent with the 137-121 Ma age range described by Bergman et al. (1996) using ${ }^{39} \mathrm{Ar}-{ }^{40} \mathrm{Ar}$ on rocks from the same formation. However, the interpretation of Metcalfe (2006) that the Luk Ulo-Meratus Suture contains Jurassic and Early Cretaceous ophiolites and pillow basalts is consistent with our model. The younger post-Eocene basalt population may be related to ophiolite obduction or deformation, as suggested by Polvé et al. (1997) and Yuwono and Maury (1988). The older age range can therefore be attributed to seafloor spreading, and may itself represent a minimum age due to the nature of $\mathrm{K}$-Ar geochronology. The bulk-rock analysis of the $\mathrm{K}$ rich basaltic dyke and diorite may have undergone significant $\mathrm{Ar}^{40}$ losses, where up to $60 \%$ of argon may be missing from $\mathrm{K}$-feldspars (orthoclase) in such rocks due to perthitization, deformation, significant exhumation (change in overburden pressure, leading to re-equilibration of orthoclase crystal resulting in perthitization) or seawater interaction (York and Farquhar, 1972). Since the samples are K-rich, it may indicate a higher proportion of orthoclase which is more likely to leak argon than plagioclase (York and Farquhar, 1972), yielding ages that are much younger. The loss of argon results in minimum ages determined from whole-rock $\mathrm{K}-\mathrm{Ar}$ geochronology, indicating that the $\sim 158$ Ma age may be a minimum rather than a maximum age. Such a scenario would require placing West Sulawesi on the New Guinea margin as seafloor spreading initiated earlier and propagated westward in the latest Jurassic (Metcalfe, 2011).

Therefore, when combining the uncertainties in ages of mafic rock fragments and the ambiguities in the alluvial diamond provenance, it can be concluded that the southwest Borneo core likely did not originate on the NW Australian shelf. However, it is entirely possible that East Java and West Sulawesi rifted from this margin in the latest Jurassic, and therefore can be classified as the elusive "Argoland" (Fig. 11). A revised model for the Meso-Tethys would allow for the transfer of these Argoland fragments to Sundaland, requiring faster spreading rates in the western Neo-Tethys in order to transfer the Argoland fragments northeastward onto the Southeast Asian margin.

\subsection{Mid-Cretaceous arc-continent collision}

Our model invokes latest Jurassic rifting of the East Borneo, East Java and West Sulawesi continental blocks from northern Gondwana, which eventually are sutured to the southwest Borneo core by $\sim 80 \mathrm{Ma}$ (Fig. 12b). During their northward motion, we model that these blocks first collide with an intra-oceanic arc at $\sim 115 \mathrm{Ma}$ following the interpretation of Wakita (2000) and based on ultra-high-pressure (UHP) metamorphic rocks exposed in the suture zone (Parkinson et al., 1998). Reports of greenschists, blueschists and eclogites from the suture zone, synthesized by Parkinson et al. (1998), indicate ongoing UHP metamorphism between 140 and $95 \mathrm{Ma}$, with a significant peak occurring between 115 and $110 \mathrm{Ma}$. We interpret the high temporal range of UHP metamorphism to be related to subduction, but infer the peak to be related to the arrival and collision of the Gondwana continental fragments. Such an interpretation is consistent with the numerical modeling of Beaumont et al. (2009), which indicate that rapid exhumation of UHP rocks occurs within $\sim 10 \mathrm{Myr}$ of a switch from subduction of oceanic crust to subduction of continental material. In addition, Ota and Kaneko (2010) classify the blueschists on Java and eastern Borneo as A-type collision-related regional metamorphic belts, rather than the B-type blueschists related to ("Pacific-type") subduction. Ota and Kaneko (2010) link the generation of A-type collision-related blueschists at 5.4 Ma $\left({ }^{40} \mathrm{Ar} /{ }^{39} \mathrm{Ar}\right.$ age; Berry and McDougall, 1986) on East Timor to the entry of Australian continental crust into the Banda subduction zone by 2.5 Ma (Bouilhol et al., 2013; Richardson and Blundell, 1996), and a similar scenario may have occurred at $\sim 115 \mathrm{Ma}$ with the arrival of the Gondwanaderived continental fragments at an intra-oceanic subduction zone. However, subduction erosion of the overriding plate, followed by exhumation, can be invoked as an alternative to our interpretation of Gondwana-derived continental blocks colliding with an intra-oceanic arc at $\sim 115 \mathrm{Ma}$. The synthesis by Agard et al. (2009) outlines three scenarios that can produce HP-LT (high pressure-low tempera- 
ture) metamorphic belts, where short-lived ( 10-15 Myr) exhumation may occur either in the early stages of subduction, short-lived ( $\sim 15-20 \mathrm{Myr})$ phase during convergence, or a period of exhumation preceding cessation of subduction. Therefore, the UHP rocks from the suture Meratus and LukUlo sutures can be interpreted to represent early subduction, convergence during subduction (and possibly a surge in convergence rates, e.g., southeast Zagros; Agard et al., 2009), or exhumation preceding collision of a continental block. Since we interpret that subduction was established well before the $\sim 115$ Ma peak in UHP metamorphism, supported by the background UHP exhumation signal between $\sim 140$ and $95 \mathrm{Ma}$ (Parkinson et al., 1998), it therefore leaves the possibility that the UHP peak was a response to changes in the forces acting on the plate boundaries at this time (Agard et al., 2009), that the Gondwana continental fragments collided directly with Sundaland and not an intra-oceanic arc (Hall, 2012), or our preferred scenario of the arrival of continental fragments to an intra-oceanic subduction zone (Wakita, 2000). The early collision of continental fragments with Sundaland at $\sim 115 \mathrm{Ma}$ is incompatible with the $\sim 80 \mathrm{Ma}$ suturing of these fragments to the Borneo core (Clements and Hall, 2011; Wakita, 2000), and therefore we prefer initial collision between East Java, East Borneo and West Sulawesi continental fragments with an intra-oceanic arc at $\sim 115 \mathrm{Ma}$. Subduction of the intervening oceanic crust, belonging to the Barito Sea, is complete by 80 Ma to obduct the Meratus ophiolites and complete continental suturing.

\subsection{Future work}

In order to better understand the convergence history between the Indo-Australian, Eurasian and Pacific plates, it will be necessary to test plate reconstruction scenarios using workflows that link plate kinematics on the surface with computational models of mantle convection (or at least, subduction) whose predictions can be compared to and validated using P- and S-wave tomography. In particular, regions with ambiguities in subduction polarities and relative plate motions, such as the Philippine Sea plate and the northern margin of New Guinea, would benefit from such testing of subduction scenarios. For continental regions, developing crustal deformation models resulting from rifting and accretion events would help account for crustal thickening and thinning histories. In particular, testing alternative models of Borneo and Sundaland oroclinal bending using deforming plate models would help test and constrain the evolution of Java Sea basins since the Eocene.

\section{Conclusions}

We present a new plate motion model that describes the tectonic evolution of northern Gondwana and Southeast Asia since the latest Jurassic, embedded in a global plate recon- struction framework. By providing the digital model, it may become a starting point for an improved understanding of the geodynamic evolution of this complex tectonic domain that links the Tethyan and proto-Pacific realms. We propose rifting of a continental fragment, consisting of West Sulawesi, East Java, and Mangkalihat, from northern Gondwana by $\sim 155 \mathrm{Ma}$. The pre-rift position is uncertain, and likely origins include the Argo Abyssal Plain and the New Guinea margin. The southwest Borneo core likely did not have a latest Jurassic origin from the NW Australian shelf, and the continuation of the Fukien-Reinan massif from east Asian and into Borneo suggests that the southwest Borneo core was already at the Asian margin in the Early Cretaceous. As a result, we prefer an accretion of West Sulawesi, East Java and Mangkalihat to the southwest Borneo core in the Late Cretaceous. We link this accretion event to the contemporaneous closure of the Woyla back arc along West Burma and Sumatra.

The Late Cretaceous also records a significant change in the character of the east Asian margin, from an Andeanstyle to an extensional back-arc setting. The onset of riftrelated tectonic subsidence from $\sim 65 \mathrm{Ma}$ can be linked to the formation of suprasubduction zone ophiolites on Mindoro and the opening of the proto-South China Sea. This back arc likely detached the Semitau continental fragment from South China and transferred it to northern Borneo in the Eocene due to Izanagi rollback, culminating in the Sarawak Orogeny in the mid- to late Eocene $(\sim 37 \mathrm{Ma}$ following Hutchison, 2010). Subduction polarity reversal began to consume the proto-South China Sea, resulting in the opening of the South China Sea from $\sim 32 \mathrm{Ma}$ which rifted the Dangerous Grounds-Reed Bank continental fragment. The south-dipping subduction at the north Borneo trench ceased at $\sim 17 \mathrm{Ma}$ when these continental fragments choked subduction and resulted in the obduction of the Palawan ophiolites and the Sabah Orogeny on Borneo. We present the first oroclinal bending model for Sundaland that is consistent with curved lineaments on the Sunda Shelf, paleomagnetic constraints and the curvature of Cretaceous-age volcanic arcs. Our preferred oroclinal bending model accounts for $\sim 80^{\circ}$ of $\mathrm{CCW}$ Borneo rotation since $\sim 50 \mathrm{Ma}$, of which $\sim 50^{\circ} \mathrm{CCW}$ motion was accommodated between $\sim 25$ and $10 \mathrm{Ma}$.

Our model attempts to reconcile the latest Jurassic-Early Cretaceous rocks on the Philippine Archipelago with a possible slab rollback and suprasubduction origin on the eastern periphery of Tethyan seafloor. We account for the formation of the Daito and Oki-Daito Ridges from 85 Ma by subduction-related rollback, and the onset of subduction along the eastern boundary of the Philippine Sea plate at $\sim 55 \mathrm{Ma}$. We implement a slab rollback model for the origin of the Caroline Plate on the eastern margin of the Philippine Sea plate, with the Torricelli-Finisterre Arc forming on the southern boundary of the Caroline Plate. The Sepik terrane first docks with northern New Guinea by $\sim 27 \mathrm{Ma}$, with the Torricelli-Finisterre Arc colliding with the leading margin 
from $6 \mathrm{Ma}$. Our model attempts to reconcile multiple lines of evidence - from surface geology to deep Earth seismic tomographic constraints, and rules of plate tectonics with evolving plate boundaries that are consistent with the relative plate motions. Our model is testable with numerical geodynamic models of mantle convection, comparisons of modeled subduction history with seismic tomographic models, whilst also forming a community framework to create open-source models and software that help improve our understanding of this complex region.

\section{Supplementary material related to this article is available online at http://www.solid-earth.net/5/227/ 2014/se-5-227-2014-supplement.zip.}

Acknowledgements. Sabin Zahirovic was supported by an Australian Postgraduate Award (APA) and a University of Sydney Vice Chancellor's Research Scholarship (VCRS), while Maria Seton and R. Dietmar Müller were supported by ARC grants FL0992245 and DP0987713. Figures were constructed using Generic Mapping Tools (Wessel and Smith, 1998; Wessel et al., 2013), GPlates, ArcGIS, GeoMapApp and TimeScale Creator. Fossil data were sourced from the Paleobiology Database (now Fossilworks, www.fossilworks.org). We thank Simon Williams for his guidance in adapting a gravity filtering workflow for the Sunda Shelf. We would like to acknowledge useful discussions with Sebastien Meffre, Nick Mortimer and Christian Heine. We thank Manuel Pubellier and Jonathan Pownall for their valuable and detailed comments, and the suggestions of the Editor (Carmen Gaina), which considerably improved the original manuscript. We dedicate the first oroclinal bending model for Sundaland to the memory and legacy of the late Charles S. Hutchison, who made immense contributions to our understanding of Southeast Asian geology.

Edited by: C. Gaina

\section{References}

Abbott, L., Silver, E., and Galawesky, J.: Structural evolution of a modern arc-continent collision in Papua New Guinea, Tectonics, 13, 1007-1034, doi:10.1029/94TC01623, 1994.

Acharyya, S.: Break-up of the greater Indo-Australian continent and accretion of blocks framing south and east Asia, J. Geodynam., 26, 149-170, doi:10.1016/S0264-3707(98)00012-X, 1998.

Agar, S., Cliff, R., Duddy, I., and Rex, D.: Short paper: Accretion and uplift in the Shimanto Belt, SW Japan, J. Geol. Soc., 146, 893-896, doi:10.1144/gsjgs.146.6.0893, 1989.

Agard, P., Yamato, P., Jolivet, L., and Burov, E.: Exhumation of oceanic blueschists and eclogites in subduction zones: timing and mechanisms, Earth-Sci. Rev., 92, 53-79, doi:10.1016/j.earscirev.2008.11.002, 2009.

Aitchison, J., Davis, A., Liu, J., Luo, H., Malpas, J., McDermid, I., Wu, H., Ziabrev, S., and Zhou, M.: Remnants of a Cretaceous intra-oceanic subduction system within the Yarlung-Zangbo suture (southern Tibet), Earth Planet. Sci. Lett., 183, 231-244, doi:10.1016/S0012-821X(00)00287-9, 2000.

Aitchison, J., Ali, J., and Davis, A.: When and where did India and Asia collide?, J. Geophys. Res., 112, B05423, doi:10.1029/2006JB004706, 2007.

Ali, J. and Aitchison, J.: Gondwana to Asia: Plate tectonics, paleogeography and the biological connectivity of the Indian sub-continent from the Middle Jurassic through latest Eocene (166-35 Ma), Earth-Sci. Rev., 88, 145-166, doi:10.1016/j.earscirev.2008.01.007, 2008.

Ali, J. R. and Hall, R.: Evolution of the boundary between the Philippine Sea Plate and Australia: palaeomagnetic evidence from eastern Indonesia, Tectonophysics, 251, 251-275, doi:10.1016/0040-1951(95)00029-1, 1995.

Altis, S.: Origin and tectonic evolution of the Caroline Ridge and the Sorol Trough, western tropical Pacific, from admittance and a tectonic modeling analysis, Tectonophysics, 313, 271-292, doi:10.1016/S0040-1951(99)00204-8, 1999.

Audley-Charles, M., Carter, D. J., Barber, A., Norvick, M., and Tjokrosapoetro, S.: Reinterpretation of the geology of Seram: implications for the Banda Arcs and northern Australia, J. Geol. Soc., 136, 547-566, doi:10.1144/gsjgs.136.5.0547, 1979.

Audley-Charles, M., Ballantyne, P., and Hall, R.: MesozoicCenozoic rift-drift sequence of Asian fragments from Gondwana, Tectonophysics, 155, 317-330, doi:10.1016/00401951(88)90272-7, 1988.

Audley-Charles, M. G.: Evolution of the southern margin of Tethys (North Australian region) from early Permian to late Cretaceous, Geol. Soc. Lond. SP, 37, 79-100, doi:10.1144/GSL.SP.1988.037.01.07, 1988.

Baldwin, S., Fitzgerald, P., and Webb, E.: Tectonics of the New Guinea Region, Annu. Rev. Earth Planet. Sci., 40, 495-520, doi:10.1146/annurev-earth-040809-152540, 2012.

Balmino, G., Vales, N., Bonvalot, S., and Briais, A.: Spherical harmonic modelling to ultra-high degree of Bouguer and isostatic anomalies, J. Geodesy, 86, 499-520, doi:10.1007/s00190-0110533-4, 2012.

Barber, A.: The origin of the Woyla Terranes in Sumatra and the late Mesozoic evolution of the Sundaland margin, J. Asian Earth Sci., 18, 713-738, doi:10.1016/S1367-9120(00)00024-9, 2000.

Barber, A. and Crow, M.: An evaluation of plate tectonic models for the development of Sumatra, Gondwana Res., 6, 1-28, doi:10.1016/S1342-937X(05)70642-0, 2003.

Barber, A. and Crow, M.: Pre-Tertiary stratigraphy, Geol. Soc. Lond. Mem., 31, 24-53, doi:10.1144/GSL.MEM.2005.031.01.04, 2005.

Barber, A. J. and Crow, M. J.: Structure of Sumatra and its implications for the tectonic assembly of Southeast Asia and the destruction of Paleotethys, Isl. Arc, 18, 3-20, doi:10.1111/j.14401738.2008.00631.x, 2009.

Barrier, E., Huchon, P., and Aurelio, M.: Philippine fault: a key for Philippine kinematics, Geology, 19, 32-35, doi:10.1130/00917613(1991)019<0032:PFAKFP>2.3.CO;2, 1991.

Beaumont, C., Jamieson, R., Butler, J., and Warren, C.: Crustal structure: A key constraint on the mechanism of ultra-highpressure rock exhumation, Earth Planet. Sci. Lett., 287, 116-129, doi:10.1016/j.epsl.2009.08.001, 2009. 
Beck, R. A., Burbank, D. W., Sercombe, W. J., Riley, G. W., Barndt, J. K., Berry, J. R., Afzal, J., Khan, A. M., Jurgen, H., and Metje, J.: Stratigraphic evidence for an early collision between northwest India and Asia, Nature, 373, 55-58, doi:10.1038/373055a0, 1995.

Bellon, H., Maury, R. C., Soeria-Atmadja, R., Cotten, J., and Polvé, M.: 65 my-long magmatic activity in Sumatra (Indonesia), from Paleocene to Present, B. Soc. Geol. Fr., 175, 61-72, doi:10.2113/175.1.61, 2004.

Ben-Avraham, Z.: The evolution of marginal basins and adjacent shelves in east and southeast Asia, Tectonophysics, 45, 269-288, doi:10.1016/0040-1951(78)90165-8, 1978.

Ben-Avraham, Z. and Uyeda, S.: The evolution of the China Basin and the Mesozoic paleogeography of Borneo, Earth Planet. Sci. Lett., 18, 365-376, doi:10.1016/0012-821X(73)90077-0, 1973.

Bergman, S. C., Dunn, D. P., and Krol, L. G.: Rock and mineral chemistry of the Linhaisai Minette, Central Kalimantan, Indonesia, and the origin of Borneo diamonds, Can. Mineral., 26, 23-43, 1988.

Bergman, S. C., Coffield, D. Q., Talbot, J. P., and Garrard, R. A.: Tertiary tectonic and magmatic evolution of western Sulawesi and the Makassar Strait, Indonesia: evidence for a Miocene continent-continent collision, Geol. Soc. Lond. SP, 106, 391429, doi:10.1144/GSL.SP.1996.106.01.25, 1996.

Berry, R. and McDougall, I.: Interpretation of 40Ar/39Ar and K/Ar dating evidence from the Aileu Formation, East Timor, Indonesia, Chemical Geology, Isotope Geosci. Sect., 59, 43-58, 1986.

Bignell, J.: The geochronology of the Malayan granites, Ph.D. Thesis, University of Oxford, 1972.

Bignold, S. and Treloar, P.: Northward subduction of the Indian Plate beneath the Kohistan island arc, Pakistan Himalaya: new evidence from isotopic data, J. Geol. Soc., 160, 377-384, doi:10.1144/0016-764902-068, 2003.

Billedo, E., Stephan, J., Delteil, J., Bellon, H., Sajona, F., and Feraud, G.: The pre-Tertiary ophiolitic complex of northeastern Luzon and the Polillo group of islands, Philippines, J. Geol. Soc. Philippin., 51, 95-114, 1996.

Bird, P.: An updated digital model of plate boundaries, Geochem. Geophy. Geosy., 4, 1027, doi:10.1029/2001GC000252, 2003.

Bouilhol, P., Jagoutz, O., Hanchar, J. M., and Dudas, F. O.: Dating the India-Eurasia collision through arc magmatic records, Earth Planet. Sci. Lett., 366, 163-175, doi:10.1016/j.eps1.2013.01.023, 2013.

Boyden, J. A., Müller, R. D., Gurnis, M., Torsvik, T. H., Clark, J. A., Turner, M., Ivey-Law, H., Watson, R. J., and Cannon, J. S.: Next-generation plate-tectonic reconstructions using GPlates, in: Geoinformatics: Cyberinfrastructure for the Solid Earth Sciences, edited by: Keller, G. and Baru, C., Cambridge University Press, Cambridge, UK, 95-114, 2011.

Briais, A., Patriat, P., and Tapponnier, P.: Updated interpretation of magnetic anomalies and seafloor spreading stages in the South China Sea: implications for the Tertiary tectonics of Southeast Asia, J. Geophys. Res., 98, 6299-6328, doi:10.1029/92JB02280, 1993.

Burg, J. P.: The Asia-Kohistan-India Collision: Review and Discussion, in: Arc-Continent Collision, edited by: Brown, D. and Ryan, P., Frontiers in Earth Sciences, Springer-Verlag Berlin, 279-309, doi:10.1007/978-3-540-88558-0_10, 2011.
Burrett, C., Zaw, K., Meffre, S., Lai, C. K., Khositanont, S., Chaodumrong, P., Udchachon, M., Ekins, S., and Halpin, J.: The configuration of Greater Gondwana - Evidence from LA ICPMS, $\mathrm{U}-\mathrm{Pb}$ geochronology of detrital zircons from the Palaeozoic and Mesozoic of Southeast Asia and China, Gondwana Res., in press, doi:10.1016/j.gr.2013.05.020, 2014.

Casey, J. and Dewey, J.: Initiation of subduction zones along transform and accreting plate boundaries, triple-junction evolution, and forearc spreading centres-implications for ophiolitic geology and obduction, Geol. Soc. Lond. SP, 13, 269-290, doi:10.1144/GSL.SP.1984.013.01.22, 1984.

Charvet, J., Lapierre, H., and Yu, Y.: Geodynamic significance of the Mesozoic volcanism of southeastern China, J. Southe. Asian Earth, 9, 387-396, doi:10.1016/0743-9547(94)90050-7, 1994.

Christensen, U.: Fixed hotspots gone with the wind, Nature, 391, 739-740, doi:10.1038/35736, 1998.

Clements, B. and Hall, R.: A record of continental collision and regional sediment flux for the Cretaceous and Palaeogene core of SE Asia: implications for early Cenozoic palaeogeography, J. Geol. Soc., 168, 1187-1200, doi:10.1144/0016-76492011-004, 2011.

Clift, P., Lee, G. H., Duc, N. A., Barckhausen, U., Van Long, H., and Zhen, S.: Seismic reflection evidence for a Dangerous Grounds miniplate: No extrusion origin for the South China Sea, Tectonics, 27, TC3008, doi:10.1029/2007TC002216, 2008.

Clift, P. D. and Lin, J.: Patterns of extension and magmatism along the continent-ocean boundary, South China margin, Geol. Soc. Lond. SP, 187 489-510, doi:10.1144/GSL.SP.2001.187.01.24, 2001.

Cobbing, E.: Granites, Geol. Soc. Lond. Mem., 31, 54-62, doi:10.1144/GSL.MEM.2005.031.01.05, 2005.

Crowhurst, P., Hill, K., Foster, D., and Bennett, A.: Thermochronological and geochemical constraints on the tectonic evolution of northern Papua New Guinea, Geol. Soc. Lond. SP, 106, Tectonic Evolution of Southeast Asia, 525-537, doi:10.1144/GSL.SP.1996.106.01.33, 1996.

Cullen, A. B. and Pigott, J. D.: Post-Jurassic tectonic evolution of Papua New Guinea, Tectonophysics, 162, 291-302, doi:10.1016/0040-1951(89)90250-3, 1989.

Cullen, A. B., Zechmeister, M., Elmore, R., and Pannalal, S.: Paleomagnetism of the Crocker Formation, northwest Borneo: Implications for late Cenozoic tectonics, Geosphere, 8, 1146-1169, doi:10.1130/GES00750.1, 2012.

Daly, M., Cooper, M., Wilson, I., Smith, D. T., and Hooper, B.: Cenozoic plate tectonics and basin evolution in Indonesia, Mar. Petrol. Geol., 8, 2-21, doi:10.1016/0264-8172(91)90041X, 1991.

Davies, H. and Jaques, A.: Emplacement of ophiolite in Papua New Guinea, Geol. Soc. Lond. SP, 13, 341-349, doi:10.1144/GSL.SP.1984.013.01.27, 1984

Davis, A., Aitchison, J., Luo, H., and Zyabrev, S.: Paleogene island arc collision-related conglomerates, Yarlung-Tsangpo suture zone, Tibet, Sediment. Geol., 150, 247-273, doi:10.1016/S00370738(01)00199-3, 2002.

Deschamps, A., and Lallemand, S.: The West Philippine Basin: An Eocene to early Oligocene back arc basin opened between two opposed subduction zones, J. Geophys. Res., 107, 2322, doi:10.1029/2001JB001706, 2002. 
De Smet, M. and Barber, A.: Tertiary stratigraphy, Geol. Soc. Lond. Mem., 31, 86-97, doi:10.1144/GSL.MEM.2005.031.01.07, 2005.

Dimalanta, C. B., Tamayo Jr., R. A., Ramos, E. G. L., Ramos, N. T., Yumul, G. P. J., Tam III., T. A., Payot, B. D., and Marquez, E. J.: Delineation of an arc-continent collision zone: Evidence from the Romblon, Tablas and Sibuyan Islands, Romblon Province, in: The 8th Field Wise Seminar on Geological Engineering Field and the 3rd International Symposium and Exhibition on Earth Resources and Geological Engineering Education Proceedings, Indonesia, 202-206, 2006.

Doglioni, C.: A proposal for the kinematic modelling of $\mathrm{W}$ dipping subductions-possible applications to the TyrrhenianApennines system, Terra Nova, 3, 423-434, doi:10.1111/j.13653121.1991.tb00172.x, 1991.

Doust, H. and Sumner, H. S.: Petroleum systems in rift basins a collective approach inSoutheast Asian basins, Petrol. Geosci., 13, 127-144, doi:10.1144/1354-079307-746, 2007.

Encarnación, J.: Multiple ophiolite generation preserved in the northern Philippines and the growth of an island arc complex, Tectonophysics, 392, 103-130, doi:10.1016/j.tecto.2004.04.010, 2004.

Engdahl, E., van der Hilst, R., and Buland, R.: Global teleseismic earthquake relocation with improved tra- vel times and procedures for depth determination, B. Seismol. Soc. Am., 88, 722743, 1998.

Faure, M., Marchadier, Y., and Rangin, C.: Pre-Eocene synmetamorphic structure in the Mindoro-Romblon-Palawan area, West Philippines, and implications for the history of Southeast Asia, Tectonics, 8, 963-979, doi:10.1029/TC008i005p00963, 1989.

Fortey, R., and Cocks, L.: Biogeography and palaeogeography of the Sibumasu terrane in the Ordovician: a review, Biogeography and Geological Evolution of SE Asia, 43-56, 1998.

Fuller, M., McCabe, R., Williams, I., Almasco, J., Encina, R., Zanoria, A., and Wolfe, J.: Paleomagnetism of Luzon, Geophys. Monogr. Ser., 27, 79-94, doi:10.1029/GM027p0079, 1983.

Fuller, M., Haston, R., Lin, J.-L., Richter, B., Schmidtke, E., and Almasco, J.: Tertiary paleomagnetism of regions around the South China Sea, J. Southe. Asian Earth, 6, 161-184, doi:10.1016/0743-9547(91)90065-6, 1991.

Fuller, M., Ali, J., Moss, S., Frost, G., Richter, B., and Mahfi, A.: Paleomagnetism of Borneo, J. Asian Earth Sci., 17, 3-24, doi:10.1016/S0743-9547(98)00057-9, 1999.

Fyhn, M. B., Pedersen, S. A., Boldreel, L. O., Nielsen, L. H., Green, P. F., Dien, P. T., Huyen, L. T., and Frei, D.: Palaeocene-early Eocene inversion of the Phuquoc-Kampot Som Basin: SE Asian deformation associated with the suturing of Luconia, J. Geol. Soc., 167, 281-295, doi:10.1144/0016-76492009-039, 2010a.

Fyhn, M. B. W., Boldreel, L. O., and Nielsen, L. H.: Escape tectonism in the Gulf of Thailand: Paleogene left-lateral pull-apart rifting in the Vietnamese part of the Malay Basin, Tectonophysics, 483, 365-376, doi:10.1016/j.tecto.2009.11.004, 2010b.

Gaina, C. and Müller, R.: Cenozoic tectonic and depth/age evolution of the Indonesian gateway and associated back-arc basins, EarthSci. Rev., 83, 177-203, doi:10.1016/j.earscirev.2007.04.004, 2007.

Geary, E. and Kay, R.: Identification of an Early Cretaceous ophiolite in the Camarines Norte-Calaguas Islands basement com- plex, eastern Luzon, Philippines, Tectonophysics, 168, 109-126, doi:10.1016/0040-1951(89)90371-5, 1989.

Geary, E., Harrison, T. M., and Heizler, M.: Diverse ages and origins of basement complexes, Luzon, Philippines, Geology, 16, 341-344, doi:10.1130/00917613(1988)016<0341:DAAOOB>2.3.CO;2, 1988.

Gibbons, A., Barckhausen, U., van den Bogaard, P., Hoernle, K., Werner, R., Whittaker, J., and Müller, R.: Constraining the Jurassic extent of Greater India: Tectonic evolution of the West Australian margin, Geochem. Geophy. Geosy., 13, Q05W13, doi:10.1029/2011GC003919, 2012.

Gibbons, A. D., Whittaker, J. M., and Müller, R. D.: The breakup of East Gondwana: Assimilating constraints from Cretaceous ocean basins around India into a best-fit tectonic model, J. Geophys. Res.-Sol. Ea., 13, Q05W13, doi:10.1002/jgrb.50079, 2013.

Golonka, J.: Plate tectonic evolution of the southern margin of Eurasia in the Mesozoic and Cenozoic, Tectonophysics, 381, 235273, doi:10.1016/j.tecto.2002.06.004, 2004.

Golonka, J.: Late Triassic and Early Jurassic palaeogeography of the world, Palaeogeogr. Palaeocl., 244, 297-307, doi:10.1016/j.palaeo.2006.06.041, 2007.

Gow, P. and Walshe, J.: The role of preexisting geologic architecture in the formation of giant porphyry-related $\mathrm{Cu} \pm \mathrm{Au}$ deposits: $\mathrm{Ex}$ amples from New Guinea and Chile, Econ. Geol., 100, 819-833, 2005.

Gradstein, F. and Ludden, J.: Radiometric age determinations for basement from Sites 765 and 766, Argo Abyssal Plain and northwestern Australian margin, Proceedings of the ocean drilling program, Scientific Results, 557-559, 1992.

Gradstein, F., Ogg, J. G., Schmitz, M., and Ogg, G.: The Geologic Time Scale 2012, Elsevier, Oxford, UK, 2012.

Gradstein, F. M., Agterberg, F. P., Ogg, J. G., Hardenbol, J., van Veen, P., Thierry, J., and Huang, Z.: A Mesozoic time scale, J. Geophys. Res., 99, 24051-24074, doi:10.1029/94JB01889, 1994.

Guntoro, A.: The formation of the Makassar Strait and the separation between SE Kalimantan and SW Sulawesi, J. Asian Earth Sci. 17, 79-98, doi:10.1016/S0743-9547(98)00037-3, 1999.

Gurnis, M., Turner, M., Zahirovic, S., DiCaprio, L., Spasojevic, S., Müller, R., Boyden, J., Seton, M., Manea, V., and Bower, D.: Plate Tectonic Reconstructions with Continuously Closing Plates, Comput. Geosci., 38, 35-42, doi:10.1016/j.cageo.2011.04.014, 2012.

Hafkenscheid, E., Wortel, M., and Spakman, W.: Subduction history of the Tethyan region derived from seismic tomography and tectonic reconstructions, J. Geophys. Res.-Sol. Ea., 111, B08401, doi:10.1029/2005JB003791, 2006.

Haile, N. and Bignell, J.: Late Cretaceous age based on K/Ar dates of granitic rock from the Tambelan and Bunguran Islands, Sunda Shelf, Indonesia, Neth. J. Geosci., 50, 687-690, 1971.

Haile, N., McElhinny, M., and McDougall, I.: Palaeomagnetic data and radiometric ages from the Cretaceous of West Kalimantan (Borneo), and their significance in interpreting regional structure, J. Geol. Soc., 133, 133-144, doi:10.1144/gsjgs.133.2.0133, 1977.

Hall, R.: Cenozoic geological and plate tectonic evolution of SE Asia and the SW Pacific: computer-based reconstructions, model and animations, J. Asian Earth Sci., 20, 353-431, doi:10.1016/S0012-821X(04)00070-6, 2002. 
Hall, R.: Australia-SE Asia collision: plate tectonics and crustal flow, Geol. Soc. Lond. SP, 355, 75-109, doi:10.1144/SP355.5, 2011.

Hall, R.: Late Jurassic-Cenozoic reconstructions of the Indonesian region and the Indian Ocean, Tectonophysics, 570-571, 1-41, doi:10.1016/j.tecto.2012.04.021, 2012.

Hall, R., Ali, J. R., and Anderson, C. D.: Cenozoic Motion of the Philippine Sea Plate - Paleomagnetic Evidence from Eastern Indonesia, Tectonics, 14, 1117-1132, doi:10.1029/95TC01694, 1995a.

Hall, R., Ali, J. R., Anderson, C. D., and Baker, S. J.: Origin and motion history of the Philippine Sea Plate, Tectonophysics, 251, 229-250, doi:10.1016/0040-1951(95)00038-0, 1995b.

Hall, R., van Hattum, M. W. A., and Spakman, W.: Impact of India-Asia collision on SE Asia: The record in Borneo, Tectonophysics, 451, 366-389, doi:10.1016/j.tecto.2007.11.058, 2008.

Hartono, H.: Summary of tectonic development of Kalimantan and adjacent areas, Energy, 10, 341-352, doi:10.1016/03605442(85)90051-9, 1985.

Haston, R. B. and Fuller, M.: Paleomagnetic data from the Philippine Sea plate and their tectonic significance, J. Geophys. Res.: Solid Earth (1978-2012), 96, 6073-6098, doi:10.1029/90JB02700, 1991.

Hawkins, J. W. and Evans, C. A.: Geology of the Zambales Range, Luzon, Philippine Islands: Ophiolite derived from an island arc-back arc basin pair, Geophys. Monogr. Ser., 27, 95-123, doi:10.1029/GM027p0095, 1983.

Hayes, D. E. and Nissen, S. S.: The South China sea margins: Implications for rifting contrasts, Earth Planet. Sci. Lett., 237, 601616, doi:10.1016/j.eps1.2005.06.017, 2005.

Hearn, P., Hare, T., Schruben, P., Sherrill, D., LaMar, C., and Tsushima, P.: Global GIS, Global Coverage DVD (USGS), American Geological Institute, Alexandria, Virginia, USA, 2003.

Heine, C. and Müller, R.: Late Jurassic rifting along the Australian North West Shelf: margin geometry and spreading ridge configuration, Aust. J. Earth Sci., 52, 27-39, doi:10.1080/08120090500100077, 2005.

Heine, C., Müller, R., and Gaina, C.: Reconstructing the Lost Eastern Tethys Ocean Basin: Convergence History of the SE Asian Margin and Marine Gateways, Geophys. Monogr., 149, 37-54, doi:10.1029/149GM03, 2004.

Heuberger, S., Schaltegger, U., Burd, J., Villa, I., Frank, M., Dawood, H., Hussain, S., and Zanchi, A.: Age and isotopic constraints on magmatism along the Karakoram- Kohistan Suture Zone, NW Pakistan: evidence for subduction and continued convergence after India-Asia collision, Swiss J. Geosci., 100, 85107, doi:10.1007/s00015-007-1203-7, 2007.

Hilde, T. W. C. and Chao-Shing, L.: Origin and evolution of the West Philippine Basin: a new interpretation, Tectonophysics, 102, 85-104, doi:10.1016/0040-1951(84)90009-X, 1984.

Hilde, T. W. C., Uyeda, S., and Kroenke, L.: Evolution of the western Pacific and its margin, Tectonophysics, 38, 145-165, doi:10.1016/0040-1951(77)90205-0, 1977.

Hill, K. and Hall, R.: Mesozoic-Cenozoic evolution of Australia's New Guinea margin in a west Pacific context, Geol. Soc. Aust. SP, 22, 265-289, 2003.

Hill, K. C.: Structure of the Papuan fold belt, Papua New Guinea, AAPG Bulletin, 75, 857-872, 1991.
Hinschberger, F., Malod, J., Réhault, J., Villeneuve, M., Royer, J., and Burhanuddin, S.: Late Cenozoic geodynamic evolution of eastern Indonesia, Tectonophysics, 404, 91-118, doi:10.1016/j.tecto.2005.05.005, 2005.

Holloway, J. and Hall, R.: SE Asian geology and biogeography: an introduction, in: Biogeography and Geological Evolution of SE Asia, edited by: Hall, R. and Holloway, J., Backhuys Publishers, Leiden, Netherlands, 1-23, 1998.

Holloway, N.: North Palawan Block, Philippines; its relation to Asian mainland and role in evolution of South China Sea, AAPG Bulletin, 66, 1355-1383, 1982.

Honza, E. and Fujioka, K.: Formation of arcs and backarc basins inferred from the tectonic evolution of Southeast Asia since the Late Cretaceous, Tectonophysics, 384, 23-53, doi:10.1016/j.tecto.2004.02.006, 2004.

Housh, T. and McMahon, T. P.: Ancient isotopic characteristics of Neogene potassic magmatism in western New Guinea (Irian Jaya, Indonesia), Lithos, 50, 217-239, doi:10.1016/S00244937(99)00043-2, 2000.

Hutchison, C. S.: Ophiolite in Southeast Asia, Geol. Soc. Am. Bull., 86, 797-806, doi:10.1130/00167606(1975)86<797:OISA>2.0.CO;2, 1975.

Hutchison, C. S.: Geological evolution of South-east Asia, Clarendon Press Oxford, 1989.

Hutchison, C. S.: The "Rajang accretionary prism" and "Lupar Line" problem of Borneo, Geol. Soc. Lond. SP, 106, 247-261, doi:10.1144/GSL.SP.1996.106.01.16, 1996.

Hutchison, C. S.: Marginal basin evolution: the southern South China Sea, Mar. Petrol. Geol., 21, 1129-1148, doi:10.1016/j.marpetgeo.2004.07.002, 2004.

Hutchison, C. S.: Oroclines and paleomagnetism in Borneo and South-East Asia, Tectonophysics, 496, 53-67, doi:10.1016/j.tecto.2010.10.008, 2010.

Hutchison, C. S., Bergman, S. C., Swauger, D. A., and Graves, J. E.: A Miocene collisional belt in north Borneo: uplift mechanism and isostatic adjustment quantified by thermochronology, J. Geol. Soc., 157, 783-793, doi:10.1144/jgs.157.4.783, 2000.

Jahn, B.-M., Chen, P., and Yen, T.: Rb-Sr ages of granitic rocks in southeastern China and their tectonic significance, Geol. Soc. Am. Bull., 87, 763-776, doi:10.1130/00167606(1976)87<763:RAOGRI>2.0.CO;2, 1976.

Johnston, S. T. and Borel, G. D.: The odyssey of the Cache Creek terrane, Canadian Cordillera: Implications for accretionary orogens, tectonic setting of Panthalassa, the Pacific superwell, and break-up of Pangea, Earth Planet. Sci. Lett., 253, 415-428, doi:10.1016/j.eps1.2006.11.002, 2007.

Jolivet, L., Huchon, P., and Rangin, C.: Tectonic setting of Western Pacific marginal basins, Tectonophysics, 160, 23-47, doi:10.1016/0040-1951(89)90382-X, 1989.

Karig, D. E.: Accreted terranes in the northern part of the Philippine Archipelago, Tectonics, 2, 211-236, doi:10.1029/TC002i002p00211, 1983.

Karig, D. E. and Jensky, W.: The proto-gulf of California, Earth Planet. Sci. Lett., 17, 169-174, doi:10.1016/0012821X(72)90272-5, 1972.

Katili, J.: Volcanism and plate tectonics in the Indonesian island arcs, Tectonophysics, 26, 165-188, doi:10.1016/00401951(75)90088-8, 1975. 
Katili, J.: Geology of Southeast Asia with particular reference to the South China Sea, Energy, 6, 1077-1091, doi:10.1016/03605442(81)90026-8, 1981.

Katili, J. A.: A review of the geotectonic theories and tectonic maps of Indonesia, Earth-Sci. Rev., 7, 143-163, doi:10.1016/00128252(71)90006-7, 1971.

Keep, M. and Harrowfield, M.: Basement reactivation and inversion mechanisms in the Timor and Norwegian seas, Geol. Soc. Lond., Petroleum Geology Conference Series, 6, 861-871, doi:10.1144/0060861, 2005.

Khan, S., Walker, D., Hall, S., Burke, K., Shah, M., and Stockli, L.: Did the Kohistan-Ladakh island arc collide first with India?, Geol. Soc. Am. Bull., 121, 366-384, doi:10.1130/B26348.1, 2009.

Kirk, H.: The igneous rocks of Sarawak and Sabah, 5, Printed at the Government Printing Office, Vincent Kiew Fah San, Govt. Printer, 1968.

Klootwijk, C., Giddings, J., Pigram, C., Loxton, C., Davies, H., Rogerson, R., and Falvey, D.: North Sepik region of Papua New Guinea: palaeomagnetic constraints on arc accretion and deformation, Tectonophysics, 362, 273-301, doi:10.1016/S00401951(02)00641-8, 2003.

Knittel, U. and Daniels, U.: Sr-isotopic composition of marbles from the Puerto Galera area (Mindoro, Philippines): Additional evidence for a Paleozoic age of a metamorphic complex in the Philippine island arc, Geology, 15, 136-138, 1987.

Lacassin, R., Replumaz, A., and Leloup, P. H.: Hairpin river loops and slip-sense inversion on southeast Asian strike-slip faults, Geology, 26, 703-706, doi:10.1130/00917613(1998)?026<0703:HRLASS>?2.3.CO;2, 1998.

Lee, T. Y. and Lawver, L. A.: Cenozoic plate reconstruction of the South China Sea region, Tectonophysics, 235, 149-180, doi:10.1016/0040-1951(94)90022-1, 1994.

Lee, T.-Y. and Lawver, L. A.: Cenozoic plate reconstruction of Southeast Asia, Tectonophysics, 251, 85-138, doi:10.1016/0040-1951(95)00023-2, 1995.

Leloup, P. H., Lacassin, R., Tapponnier, P., Schärer, U., Dalai, Z., Xiaohan, L., Liangshang, Z., Shaocheng, J., and Trinh, P. T.: The Ailao Shan-Red River shear zone (Yunnan, China), Tertiary transform boundary of Indochina, Tectonophysics, 251, 3-10, doi:10.1016/0040-1951(95)00070-4, 1995.

Leloup, P. H., Arnaud, N., Lacassin, R., Kienast, J., Harrison, T., Trong, T. T. P., Replumaz, A., and Tapponnier, P.: New constraints on the structure, thermochronology, and timing of the Ailao Shan-Red River shear zone, SE Asia, J. Geophys. Res., 106, 6683-6732, doi:10.1029/2000JB900322, 2001.

Leloup, P. H., Tapponnier, P., and Lacassin, R.: Discussion on the role of the Red River shear zone, Yunnan and Vietnam, in the continental extrusion of SE Asia, J. Geol. Soc., 164, 1253-1260, doi:10.1144/0016-76492007-065, 2007.

Li, C., van der Hilst, R., Engdahl, E., and Burdick, S.: A new global model for P wave speed variations in Earth's mantle, Geochem. Geophy. Geosy., 9, Q05018, doi:10.1029/2007GC001806, 2008.

Li, X.: Cretaceous magmatism and lithospheric extension in Southeast China, J. Asian Earth Sci., 18, 293-305, doi:10.1016/S13679120(99)00060-7, 2000.

Li, Z. X., Li, X. H., Chung, S. L., Lo, C. H., Xu, X., and Li, W. X.: Magmatic switch-on and switch-off along the South China continental margin since the Permian: Transition from an Andean- type to a Western Pacific-type plate boundary, Tectonophysics, 532-535, 271-290, doi:10.1016/j.tecto.2012.02.011, 2012.

Lin, A., Watts, A., and Hesselbo, S.: Cenozoic stratigraphy and subsidence history of the South China Sea margin in the Taiwan region, Basin Res., 15, 453-478, doi:10.1046/j.13652117.2003.00215.x, 2003.

Mammerickx, J. and Klitgord, K. D.: Northern East Pacific Rise: Evolution from 25 my BP to the present, J. Geophys. Res.: Solid Earth (1978-2012), 87, 6751-6759, doi:10.1029/JB087iB08p06751, 1982.

Matsuda, J.: Sr isotope studies of rocks from Philippine Sea and some implication for the mantle material, in: Geology of the Northern Philippine Sea, edited by: Shiki, T., Tokai University Press, Shimizu, 63-78, 1985.

McCourt, W., Crow, M., Cobbing, E., and Amin, T.: Mesozoic and Cenozoic plutonic evolution of SE Asia: evidence from Sumatra, Indonesia, Geol. Soc. Lond. SP, 106, 321-335, doi:10.1144/GSL.SP.1996.106.01.21, 1996.

McKenzie, D. and Morgan, W.: Evolution of Triple Junctions, Nature, 224, 125-133, doi:10.1038/224125a0, 1969.

Metcalfe, I.: Gondwana origin, dispersion, and accretion of East and Southeast Asian continental terranes, J. S. Am. Earth Sci., 7, 333-347, doi:10.1016/0895-9811(94)90019-1, 1994.

Metcalfe, I.: Pre-Cretaceous evolution of SE Asian terranes, Geol. Soc. Lond. SP, 106, 97-122, doi:10.1144/GSL.SP.1996.106.01.09, 1996.

Metcalfe, I.: Gondwana dispersion and Asian accretion: an overview, in: Gondwana dispersion and Asian Accretion, edited by: Metcalfe, I., A. A. Balkema, Rotterdam, 9-28, 1999.

Metcalfe, I.: Palaeozoic and Mesozoic tectonic evolution and palaeogeography of East Asian crustal fragments: The Korean Peninsula in context, Gondwana Res., 9, 24-46, doi:10.1016/j.gr.2005.04.002, 2006.

Metcalfe, I.: Tectonic framework and Phanerozoic evolution of Sundaland, Gondwana Res., 19, 3-21, doi:10.1016/j.gr.2010.02.016, 2011.

Milsom, J., Ali, J. R., and Queano, K. L.: Peculiar geometry of northern Luzon, Philippines: Implications for regional tectonics of new gravity and paleomagnetic data, Tectonics, 25, TC4017, doi:10.1029/2005TC001930, 2006.

Mitchell, A.: Cretaceous-Cenozoic tectonic events in the western Myanmar (Burma)-Assam region, J. Geol. Soc., 150, 10891102, doi:10.1144/gsjgs.150.6.1089, 1993.

Mitchell, A., Chung, S.-L., Oo, T., Lin, T.-H., and Hung, C.-H.: Zircon U-Pb ages in Myanmar: Magmatic-metamorphic events and the closure of a neo-Tethys ocean?, J. Asian Earth Sci., 56123, doi:10.1016/j.jseaes.2012.04.019, 2012.

Molnar, P. and Tapponnier, P.: Cenozoic tectonics of Asia: effects of a continental collision, Science, 189, 419-426, doi:10.1126/science.189.4201.419, 1975.

Monnier, C., Girardeau, J., Pubellier, M., Polvé, M., Permana, H., and Bellon, H.: Petrology and geochemistry of the Cyclops ophiolites (Irian Jaya, East Indonesia): consequences for the Cenozoic evolution of the north Australian margin, Mineral. Petrol., 65, 1-28, doi:10.1007/BF01161574, 1999.

Monnier, C., Girardeau, J., Pubellier, M., and Permana, H.: The central ophiolite belt of Irian Jaya (Indonesia): petrological and geochemical evidence for a back-arc basin origin, CR Acad. Sci. II, 331, 691-699, doi:10.1016/S1251-8050(00)01479-8, 2000. 
Morley, C.: Variations in Late Cenozoic-Recent strike-slip and oblique-extensional geometries, within Indochina: The influence of pre-existing fabrics, J. Struct. Geol., 29, 36-58, doi:10.1016/j.jsg.2006.07.003, 2007.

Morley, C.: Late cretaceous-early Palaeogene tectonic development of SE Asia, Earth-Sci. Rev., 115, 37-75, doi:10.1016/j.earscirev.2012.08.002, 2012.

Müller, R., Gaina, C., Roest, W., and Hansen, D.: A recipe for microcontinent formation, Geology, 29, 203-206, doi:10.1130/0091-7613(2001)029<0203:ARFMF>2.0.CO;2, 2001.

Müller, R., Sdrolias, M., Gaina, C., and Roest, W.: Age, spreading rates, and spreading asymmetry of the world's ocean crust, Geochem. Geophy. Geosy., 9, Q04006, doi:10.1029/2007GC001743, 2008.

Norvick, M.: The tectonic history of the Banda Arcs, eastern Indonesia: a review, J. Geol. Soc., 136, 519-526, doi:10.1144/gsjgs.136.5.0519, 1979.

O’Neill, C., Müller, R., and Steinberger, B.: On the uncertainties in hot spot reconstructions and the significance of moving hot spot reference frames, Geochem. Geophy. Geosy., 6, Q04003, doi:10.1029/2004GC000784, 2005.

Oskin, M. and Stock, J.: Pacific-North America plate motion and opening of the Upper Delfín basin, northern Gulf of California, Mexico, Geol. Soc. Am. Bull., 115, 1173-1190, doi:10.1130/B25154.1, 2003.

Ota, T. and Kaneko, Y.: Blueschists, eclogites, and subduction zone tectonics: Insights from a review of Late Miocene blueschists and eclogites, and related young highpressure metamorphic rocks, Gondwana Research, 18, 167-188, doi:10.1016/j.gr.2010.02.013, 2010

Parkinson, C., Miyazaki, K., Wakita, K., Barber, A., and Carswell, D.: An overview and tectonic synthesis of the preTertiary very-high-pressure metamorphic and associated rocks of Java, Sulawesi and Kalimantan, Indonesia, Isl. Arc, 7, 184-200, doi:10.1046/j.1440-1738.1998.00184.x, 1998.

Pedersen, R., Searle, M., Carter, A., and Bandopadhyay, P.: U-Pb zircon age of the Andaman ophiolite: implications for the beginning of subduction beneath the Andaman-Sumatra arc, J. Geol. Soc., 167, 1105-1112, doi:10.1144/0016-76492009-151, 2010.

Petterson, M. G. and Windley, B. F.: RbSr dating of the Kohistan arc-batholith in the Trans-Himalaya of north Pakistan, and tectonic implications, Earth Planet. Sci. Lett., 74, 45-57, doi:10.1016/0012-821X(85)90165-7, 1985.

Pigram, C. and Symonds, P.: A review of the timing of the major tectonic events in the New Guinea Orogen, J. Southe. Asian Earth, 6, 307-318, doi:10.1016/0743-9547(91)90076-A, 1991.

Pigram, C., Davies, P., Feary, D., and Symonds, P.: Tectonic controls on carbonate platform evolution in southern Papua New Guinea: Passive margin to foreland basin, Geology, 17199-202, doi:10.1130/0091-7613(1989)017<0199:TCOCPE>2.3.CO;2, 1989.

Polvé, M., Maury, R., Bellon, H., Rangin, C., Priadi, B., Yuwono, S., Joron, J., and Atmadja, R. S.: Magmatic evolution of Sulawesi (Indonesia): constraints on the Cenozoic geodynamic history of the Sundaland active margin, Tectonophysics, 272, 6992, doi:10.1016/S0040-1951(96)00276-4, 1997.
Pubellier, M. and Meresse, F.: Phanerozoic growth of Asia: Geodynamic processes and evolution, J. Asian Earth Sci., 72, 118-128, doi:10.1016/j.jseaes.2012.06.013, 2013.

Pubellier, M., Ego, F., Chamot-Rooke, N., and Rangin, C.: The building of pericratonicmountain ranges: structural and kinematic constraints applied to GIS-based reconstructions of SE Asia, B. Soc. Geol. Fr., 174, 561-584, 10.2113/174.6.561, 2003.

Pubellier, M., Monnier, C., Maury, R., and Tamayo, R.: Plate kinematics, origin and tectonic emplacement of suprasubduction ophiolites in SE Asia, Tectonophysics, 392, 9-36, doi:10.1016/j.tecto.2004.04.028, 2004.

Queano, K. L., Ali, J. R., Milsom, J., Aitchison, J. C., and Pubellier, M.: North Luzon and the Philippine Sea Plate motion model: Insights following paleomagnetic, structural, and age-dating investigations, J. Geophys. Res., 112, B05101, doi:10.1029/2006JB004506, 2007.

Rangin, C., Stephan, J., and Müller, C.: Middle Oligocene oceanic crust of South China Sea jammed into Mindoro collision zone (Philippines), Geology, 13, 425-428, doi:10.1130/00917613(1985)13<425:MOOCOS>2.0.CO;2, 1985.

Rangin, C., Jolivet, L., and Pubellier, M.: A simple model for the tectonic evolution of southeast Asia and Indonesia region for the past 43 my, B. Soc. Geol. Fr., 6, 889-905, 1990.

Rehault, J., Moussat, E., and Fabbri, A.: Structural evolution of the Tyrrhenian back-arc basin, Mar. Geol., 74, 123-150, doi:10.1016/0025-3227(87)90010-7, 1987.

Rehman, H. U. R., Seno, T., Yamamoto, H., and Khan, T.: Timing of collision of the Kohistan-Ladakh Arc with India and Asia: Debate, Isl. Arc, 20, 308-328, doi:10.1111/j.14401738.2011.00774.x, 2011.

Ren, J., Tamaki, K., Li, S., and Junxia, Z.: Late Mesozoic and Cenozoic rifting and its dynamic setting in Eastern China and adjacent areas, Tectonophysics, 344, 175-205, doi:10.1016/S00401951(01)00271-2, 2002.

Replumaz, A., Lacassin, R., Tapponnier, P., and Leloup, P. H.: Large river offsets and Plio-Quaternary dextral slip rate on the Red River fault (Yunnan, China), J. Geophys. Res., 106, 819-836, doi:10.1029/2000JB900135, 2001

Richards, S., Lister, G., and Kennett, B.: A slab in depth Three-dimensional geometry and evolution of the IndoAustralian plate, Geochem. Geophy. Geosy., 8, Q12003, doi:10.1029/2007GC001657, 2007.

Richardson, A. and Blundell, D.: Continental collision in the Banda Arc, Geol. Soc. Lond. SP, 106, 47-60, doi:10.1144/GSL.SP.1996.106.01.05, 1996.

Robb, M. S., Taylor, B., and Goodliffe, A. M.: Re examination of the magnetic lineations of the Gascoyne and Cuvier Abyssal Plains, off NW Australia, Geophys. J. Int., 163, 42-55, doi:10.1111/j.1365-246X.2005.02727.x, 2005.

Rowley, D. B.: Age of initiation of collision between India and Asia: A review of stratigraphic data, Earth Planet. Sci. Lett., 145, 1-13, doi:10.1016/S0012-821X(96)00201-4, 1996.

Royer, J. Y. and Sandwell, D. T.: Evolution of the eastern Indian Ocean since the Late Cretaceous: Constraints from Geosat altimetry, J. Geophys. Res.-Sol. Ea. (1978-2012), 94, 1375513782, doi:10.1029/JB094iB10p13755, 1989.

Ruban, D. A., Conrad, C. P., and van Loon, A. J. T.: The challenge of reconstructing the Phanerozoic sea level and the Pacific Basin 
tectonics, Geologos, 16, 235-243, 10.2478/v10118-010-0007-9, 2010.

Ryan, W. B., Carbotte, S. M., Coplan, J. O., O’Hara, S., Melkonian, A., Arko, R., Weissel, R. A., Ferrini, V., Goodwillie, A., and Nitsche, F.: Global Multi-Resolution Topography synthesis, Geochem. Geophy. Geosy., 10, Q03014, doi:10.1029/2008GC002332, 2009.

Ryburn, R.: Blueschists and associated rocks in the south Sepik region, Papua New Guinea; field relations, petrology, mineralogy, metamorphism and tectonic setting, Univ. Auckland, Auckland, NZ, 1980.

Sandwell, D. and Smith, W.: Global marine gravity from retracked Geosat and ERS-1 altimetry: Ridge segmentation versus spreading rate, J. Geophys. Res.-Sol. Ea., 114, B01411, doi:10.1029/2008JB006008, 2009.

Sarewitz, D. R. and Karig, D. E.: Geologic evolution of western Mindoro Island and the Mindoro suture zone, Philippines, J. Southe. Asian Earth, 1, 117-141, doi:10.1016/07439547(86)90026-7, 1986.

Schlüter, H., Hinz, K., and Block, M.: Tectono-stratigraphic terranes and detachment faulting of the South China Sea and Sulu Sea, Mar. Geol., 130, 39-78, doi:10.1016/0025-3227(95)001379, 1996.

Schmidtke, E. A., Fuller, M. D., and Haston, R. B.: Paleomagnetic data from Sarawak, Malaysian Borneo, and the late Mesozoic and Cenozoic tectonics of Sundaland, Tectonics, 9, 123-140, doi:10.1029/TC009i001p00123, 1990.

Sdrolias, M. and Müller, R. D.: Controls on back-arc basin formation, Geochem. Geophy. Geosy., 7, Q04016, doi:10.1029/2005GC001090, 2006.

Sdrolias, M., Roest, W. R., and Müller, R. D.: An expression of Philippine Sea plate rotation: the Parece Vela and Shikoku basins, Tectonophysics, 394, 69-86, doi:10.1016/j.tecto.2004.07.061, 2004.

Şengör, A., Altıner, D., Cin, A., Ustaömer, T., and Hsü, K.: Origin and assembly of the Tethyside orogenic collage at the expense of Gondwana Land, Geol. Soc. Lond. SP, 37, 119-181, doi:10.1144/GSL.SP.1988.037.01.09, 1988.

Seton, M. and Müller, R.: Reconstructing the junction between Panthalassa and Tethys since the Early Cretaceous, Eastern Australasian Basins III. Petroleum Exploration Society of Australia, Special Publications, 263-266, 2008.

Seton, M., Müller, R., Zahirovic, S., Gaina, C., Torsvik, T., Shephard, G., Talsma, A., Gurnis, M., Turner, M., Maus, S., and Chandler, M.: Global continental and ocean basin reconstructions since $200 \mathrm{Ma}$, Earth-Sci. Rev., 113, 212-270, doi:10.1016/j.earscirev.2012.03.002, 2012.

Simmons, N., Forte, A., and Grand, S.: Joint seismic, geodynamic and mineral physical constraints on three-dimensional mantle heterogeneity: Implications for the relative importance of thermal versus compositional heterogeneity, Geophys. J. Int., 177, 1284-1304, doi:10.1111/j.1365-246X.2009.04133.x, 2009.

Smith, C. B., Bulanova, G. P., Kohn, S. C., Milledge, H. J., Hall, A. E., Griffin, B. J., and Pearson, D. G.: Nature and genesis of Kalimantan diamonds, Lithos, 112, 822-832, doi:10.1016/j.lithos.2009.05.014, 2009.

Smyth, H. R., Hamilton, P. J., Hall, R., and Kinny, P. D.: The deep crust beneath island arcs: Inherited zircons reveal a Gondwana continental fragment beneath East Java, Indonesia, Earth Planet. Sci. Lett., 258, 269-282, doi:10.1016/J.Epsl.2007.03.044, 2007.

Soeria-Atmadja, R., Noeradi, D., and Priadi, B.: Cenozoic magmatism in Kalimantan and its related geodynamic evolution, J. Asian Earth Sci., 17, 25-45, doi:10.1016/S0743-9547(98)000622, 1999.

Sone, M., Metcalfe, I., and Chaodumrong, P.: The Chanthaburi terrane of southeastern Thailand: Stratigraphic confirmation as a disrupted segment of the Sukhothai Arc, J. Asian Earth Sci., 61, 16-32, doi:10.1016/j.jseaes.2012.08.021, 2012.

Spencer, J. E., and Normark, W. R.: Tosco-Abreojos fault zone: A Neogene transform plate boundary within the Pacific margin of southern Baja California, Mexico, Geology, 7, 554-557, doi:10.1130/0091-7613(1979)7<554:TFZANT>2.0.CO;2, 1979.

Stampfli, G. M., and Borel, G. D.: A plate tectonic model for the Paleozoic and Mesozoic constrained by dynamic plate boundaries and restored synthetic oceanic isochrons, Earth Planet. Sci. Lett., 196, 17-33, doi:10.1016/S0012-821X(01)00588-X, 2002.

Stauffer, P. H.: Unraveling the mosaic of Paleozoic crustal blocks in Southeast Asia, Geol. Rundsch., 72, 1061-1080, doi:10.1007/BF01848354, 1983.

Steinberger, B. and Torsvik, T. H.: Absolute plate motions and true polar wander in the absence of hotspot tracks, Nature, 452, 620 623, doi:10.1038/nature06824, 2008.

Stern, R. J. and Bloomer, S. H.: Subduction zone infancy: examples from the Eocene Izu-Bonin-Mariana and Jurassic California arcs, Geol. Soc. Am. Bull., 104, 1621-1636, doi:10.1130/00167606(1992)104<1621:SZIEFT>2.3.CO;2, 1992.

Sukamoto, R. and Westermann, G.: The Jurassic of the Circum- Pacific, Indonesia and Papua New Guinea, edited by: Westermann, G., Cambridge University Press, 1992.

Tapponnier, P., Peltzer, G., Le Dain, A. Y., Armijo, R., and Cobbold, P.: Propagating extrusion tectonics in Asia: New insights from simple experiments with plasticine, Geology, 10, 611-616, doi:10.1130/0091-7613(1982)10<611:petian>2.0.co;2, 1982.

Tapponnier, P., Lacassin, R., Leloup, P. H., Scharer, U., Dalai, Z., Haiwei, W., Xiaohan, L., Shaocheng, J., Lianshang, Z., and Jiayou, Z.: The Ailao Shan/Red River metamorphic belt: Tertiary left-lateral shear between Indochina and South China, Nature, 343, 6257, 431-437, doi:10.1038/343431a0, 1990.

Tarduno, J., Bunge, H. P., Sleep, N., and Hansen, U.: The bent Hawaiian-Emperor hotspot track: Inheriting the mantle wind, science, 324, 50-53, doi:10.1126/science.1161256, 2009.

Taylor, W. R., Jaques, A. L., and Ridd, M.: Nitrogen-defect aggregation characteristics of some Australasian diamonds: Timetemperature constraints on the source regions of pipe and alluvial diamonds, Am. Mineral., 75, 1290-1310, 1990.

Tokuyama, H.: Origin and development of the Philippine Sea, Geol. Geophys. Philippin. Sea, 155-163, 1995.

Tongkul, F.: The geology of Northern Sabah, Malaysia: its relationship to the opening of the South China Sea Basin, Tectonophysics, 235, 131-147, doi:10.1016/0040-1951(94)90021-3, 1994.

Torsvik, T., Müller, R., Van der Voo, R., Steinberger, B., and Gaina, C.: Global plate motion frames: toward a unified model, Rev. Geophys., 46, RG3004, doi:10.1029/2007RG000227, 2008a.

Torsvik, T., Steinberger, B., Cocks, L., and Burke, K.: Longitude: linking Earth's ancient surface to its deep interior, Earth Planet. Sci. Lett., 276, 273-282, doi:10.1016/j.eps1.2008.09.026, 2008b. 
Van Der Meer, D., Spakman, W., van Hinsbergen, D., Amaru, M., and Torsvik, T.: Towards absolute plate motions constrained by lower-mantle slab remnants, Nat. Geosci., 336-40, doi:10.1038/ngeo708, 2010.

Van der Voo, R., Spakman, W., and Bijwaard, H.: Tethyan subducted slabs under India, Earth Planet. Sci. Lett., 171, 7-20, doi:10.1016/S0012-821X(99)00131-4, 1999.

van Hilten, D.: Presentation of paleomagnetic data, polar wandering, and continental drift, Am. J. Sci., 260, 401-426, 10.2475/ajs.260.6.401, 1962.

Veevers, J.: Phanerozoic Australia in the changing configuration of Proto-Pangea through Gondwana and Pangea to the present dispersed continents, Aust. System. Bot., 4, 1-11, doi:10.1071/SB9910001, 1991.

Veevers, J.: Gondwana from 650-500 Ma assembly through $320 \mathrm{Ma}$ merger in Pangea to 185-100 Ma breakup: supercontinental tectonics via stratigraphy and radiometric dating, Earth-Sci. Rev., 68, 1-132, doi:10.1016/j.earscirev.2004.05.002, 2004.

Veevers, J., Powell, C., and Roots, S.: Review of seafloor spreading around Australia. I. Synthesis of the patterns of spreading, Aust. J. Earth Sci., 38, 373-389, doi:10.1080/08120099108727979, 1991.

Wajzer, M., Barber, A., and Hidayat, S.: Accretion, collision and strike-slip faulting: the Woyla group as a key to the tectonic evolution of North Sumatra, J. Southe. Asian Earth, 6, 447-461, doi:10.1016/0743-9547(91)90087-E, 1991.

Wakita, K.: Cretaceous accretionary-collision complexes in central Indonesia, J. Asian Earth Sci., 18, 739-749, doi:10.1016/S13679120(00)00020-1, 2000.

Watkinson, I., Elders, C., and Hall, R.: The kinematic history of the Khlong Marui and Ranong Faults, southern Thailand, J. Struct. Geol., 30, 1554-1571, doi:10.1016/j.jsg.2008.09.001, 2008.

Weissel, J. K. and Anderson, R. N.: Is there a Caroline plate?, Earth Planet. Sci. Lett., 41, 143-158, doi:10.1016/0012821X(78)90004-3, 1978.

Wessel, P. and Smith, W. H.: New, improved version of Generic Mapping Tools released, Eos T. Am. Geophys. Un., 79, 579-579, doi:10.1029/98EO00426, 1998.

Wessel, P., Smith, W. H., Scharroo, R., Luis, J., and Wobbe, F.: Generic Mapping Tools: Improved Version Released, Eos T. Am. Geophys. Un., 94, 409-410, doi:10.1002/2013EO450001, 2013.

Whittaker, J., Müller, R., Sdrolias, M., and Heine, C.: Sunda-Java trench kinematics, slab window formation and overriding plate deformation since the Cretaceous, Earth Planet. Sci. Lett., 255, 445-457, doi:10.1016/j.epsl.2006.12.031, 2007.

Williams, P., Johnston, C., Almond, R., and Simamora, W.: Late Cretaceous to early Tertiary structural elements of West Kalimantan, Tectonophysics, 148, 279-297, doi:10.1016/00401951(88)90135-7, 1988.

Williams, S., Whittaker, J., and Müller, R.: Full-fit, palinspastic reconstruction of the conjugate Australian-Antarctic margins, Tectonics, 30, TC6012, doi:10.1029/2011TC002912, 2011.
Worthing, M. and Crawford, A.: The igneous geochemistry and tectonic setting of metabasites from the Emo Metamorphics, Papua New Guinea; a record of the evolution and destruction of a backarc basin, Mineral. Petrol., 58, 79-100, doi:10.1007/BF01165765, 1996.

Wu, J., Suppe, J., and Kanda, R.: Cenozoic East Asia plate tectonic reconstructions using constraints of mapped and unfolded slabs from mantle seismic tomography, 2012 Fall Meeting, AGU, San Francisco, California, 3-7 December, Abstract 1496913, 2012.

Yang, S., Hu, S., Cai, D., Feng, X., Chen, L., and Gao, L.: Present-day heat flow, thermal history and tectonic subsidence of the East China Sea Basin, Mar. Petrol. Geol., 21, 1095-1105, doi:10.1016/j.marpetgeo.2004.05.007, 2004.

York, D. and Farquhar, R.: The Earth's Age and Geochronology, Pergamon Press, 178 pp., 1972.

Yumul, G. P., Dimalanta, C. B., Marquez, E. J., and Queaño, K. L.: Onland signatures of the Palawan microcontinental block and Philippine mobile belt collision and crustal growth process: A review, J. Asian Earth Sci., 34, 610-623, doi:10.1016/j.jseaes.2008.10.002, 2009.

Yumul Jr., G. P., Dimalanta, C. B., Tamayo Jr, R. A., and Maury, R. C.: Collision, subduction and accretion events in the Philippines: A synthesis, Isl. Arc, 12, 77-91, doi:10.1046/j.14401738.2003.00382.x, 2003.

Yuwono, Y. and Maury, R.: Tertiary and Quaternary geodynamic evolution of South Sulawesi: constraints from the study of volcanic units, Geol. Indonesia, 13, 15-22, 1988.

Yuwono, Y., Priyomarsono, S., Maury, R., Rampnoux, J., SoeriaAtmadja, R., Bellon, H., and Chotin, P.: Petrology of the Cretaceous magmatic rocks from Meratus Range, southeast Kalimantan, J. Southe. Asian Earth, 2, 15-22, doi:10.1016/07439547(88)90017-7, 1988.

Zahirovic, S., Müller, R. D., Seton, M., Flament, N., Gurnis, M., and Whittaker, J.: Insights on the kinematics of the India-Eurasia collision from global geodynamic models, Geochem. Geophy. Geosy., 13, Q04W11, doi:10.1029/2011gc003883, 2012.

Zhou, D., Sun, Z., Chen, H., Xu, H., Wang, W., Pang, X., Cai, D., and Hu, D.: Mesozoic paleogeography and tectonic evolution of South China Sea and adjacent areas in the context of Tethyan and Paleo-Pacific interconnections, Isl. Arc, 17, 186207, doi:10.1111/j.1440-1738.2008.00611.x, 2008.

Zhu, D.-C., Zhao, Z.-D., Niu, Y., Dilek, Y., and Mo, X.-X.: Lhasa terrane in southern Tibet came from Australia, Geology, 39, 727 730, doi:10.1130/G31895.1, 2011.

Ziabrev, S., Aitchison, J., and Abrajevitch, A.: Bainang Terrane, Yarlung-Tsangpo suture, southern Tibet (Xizang, China): a record of intra-Neotethyan subduction-accretion processes preserved on the roof of the world, J. Geol. Soc., 161, 523-539, doi:10.1144/0016-764903-099, 2004. 